Buku ini sangat penting untuk dipelajari sebagai materi misi dan penginjilan, dengan follow up-nya adalah terbangunnya pemuridan di gereja yang ditanam. Saya mendorong gereja dan para pendeta perlu mempraktikkan pelayanan misi lintas budaya yang kontekstual.

-Pdt. Dr. Niko Njotorahardjo

Buku ini akan sangat penting dan berguna bagi para mahasiswa teologia, baik di tingkat strata satu sampai pasca sarjana, untuk mempelajari, mendiskusikan, serta membuat studi komparatif selanjutnya, sebagai materi yang sangat dibutuhkan bagi sekolah-sekolah teologia khususnya dan para hamba Tuhan dan gereja yang ingin mendalami dan bergerak dalam lingkup apostoliknya karena ditulis oleh seorang praktisi misi dan penanam gereja yang berpengalaman dan diurapi di bidangnya.

-Pdt. Djohan Handojo, M.Th.

Misi adalah rencana Allah yang kekal. Bangsa Israel dipilih dan dipanggil Allah untuk melakukan tugas misi supaya bangsa lain mengenal dan memuliakan Allah. Demikian juga halnya dengan gereja. Semua orang percaya harus melaksanakan misi Allah karena mereka adalah milik Allah. Misi Allah bukan hanya kepada orang Yahudi, melainkan juga non-Yahudi. Tujuan misi Allah supaya manusia diselamatkan sehingga nama dan reputasi Allah yang diutamakan di atas kepentingan manusia. Oleh karena itu, misi PL dan PB bukanlah hal yang terpisah, melainkan berkesinambungan.

Selain tujuan dan pengertian misi, buku ini memaparkan pengalamanpengalaman sederhana yang dialami penulis serta data-data yang mendukung untuk menunjang pergerakan misi. Model keuangan misi dan bagaimana merekrut tenaga misi dan model pelatihannya. Buku ini akan menginspirasi mahasiswa, praktisi misi, dan gereja untuk bergerak dalam penuaian akhir zaman.
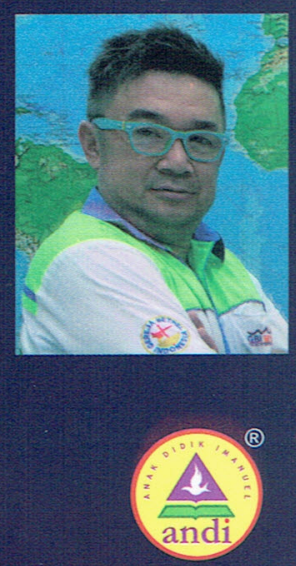

www.bukurohani.con www.bukurohaniandi.com Dapatkan info buku baru dengan

Fransiskus Irwan Widjaja adalah Doctor of Theology Konsentrasi Misi STT Real Batam, PhD candidate dari BIU Singapore, Alumni Oklahoma State University, 1989, Stillwater USA, penulis juga pengajar Pasca Sarjana (S2 \& S3), menggembalakan GBI My Home Rawasari di Tanjung Pinang, pastor in charge untuk gereja-gereja misi di Kepulauan Riau dan Asia Tenggara, World Mission Director dari BCS Singapore (2001-sekarang), SEACPN (South East Asia Church Planting Network) Fasilitator 2013-2015, Executive Committee GCPN London (Global Church Planting Network), 2014-sekarang, Majelis Pekerja Lengkap (MPL) GBI (2014-2018), pendiri Asosiasi Misi Indonesia 2016 Haggai Faculty, dan sekarang sedang menjabat Ketua Yayasan Transformas Indonesia Cerdas (2017-sekarang)

Gereja \& Pelayanan/Penginjilan \& Misi/M ISBN 978-979-29-6630-5

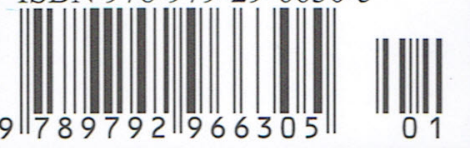




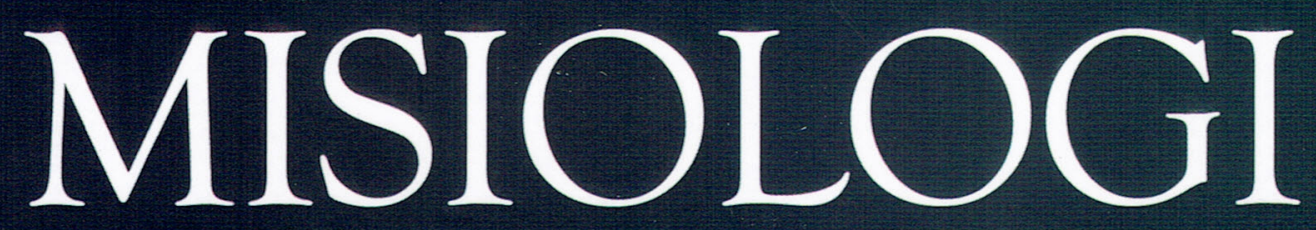

\section{ANTARA TEORI, FAKTA dan PENGALAMAN}

FRANSISKUS IRWAN WIDJAJA

\section{Editor:}

Irfan Feriando Simanjuntak Fredy Simanjuntak 


\section{Teristimewa untuk:}

\section{Teriring Doa dan Cinta:}

\section{Tanggal:}




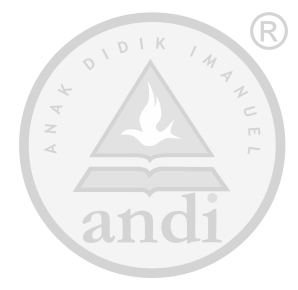




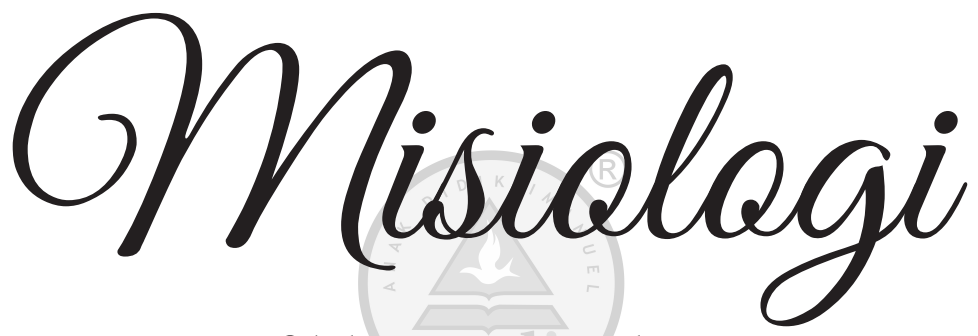

Oleh: F. Irwan widjaja

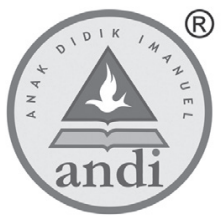

Penerbit ANDI - Yogyakarta 
Misiologi

Oleh: F. Irwan widjaja

Hak cipta @ 2018 pada penulis

... +...; $15 \times 23 \mathrm{~cm}$

1. Misi 2. Pemuridan

DDC. 248

ISBN:

Penerbit ANDI

(Penerbit Buku dan Majalah Rohani)

Anggota IKAPI

Jl. Beo 38-40 Yogyakarta 55281

Surel: editor.pbr@gmail.com

Telp.: 0274-561881, 584858; Fax.: 0274-523160

Dilarang memperbanyak sebagian atau seluruh isi buku ini dalam bentuk apa pun tanpa izin tertulis dari penerbit/penulis sesuai Undang-undang Hak Cipta dan moral kristiani.

\begin{tabular}{|c|c|}
\hline PBRA & $:$ \\
\hline Peredaksi & : Dian Christine Fitriasar \\
\hline Penata Letak & $:$ \\
\hline Desain sampul & : \\
\hline Percetakan & : Andi Offset Yogyakarta \\
\hline Cetakan ke & $: \begin{array}{lllll}5 & 4 & 3 & 2 & 1\end{array}$ \\
\hline Tahun & : 2221201918 \\
\hline
\end{tabular}




\section{Daftar Isi}

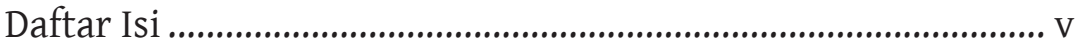

Kata Pengantar ........................................................................... vii

1 Misi dalam Perjanjian Lama dan Perjanjian Baru .................1

2 Mission In Action Bermisi

Menanam Gereja Itu Mudah (Asal Tahu Caranya) ...............47

3 Dasar-dasar Firman dan Filosofi dalam

Pelayanan Misi ....................................................................73

4 Model dan Motif Misi .........................................................99

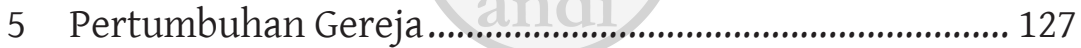

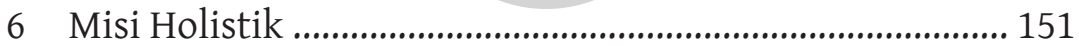

7 Keuangan Misi................................................................... 163

8 Merekrut Tenaga Misi \& Fakta-fakta yang Perlu Diketahui ..................................................... 173

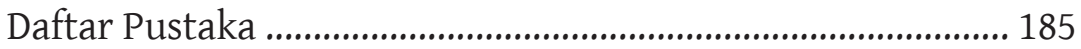

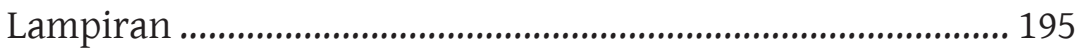




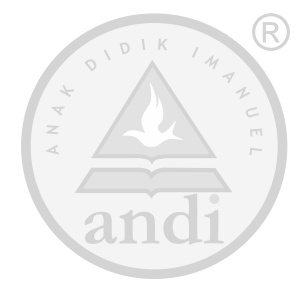




\section{Kata Pengantar}

Shalom,

Buku ini merupakan buku yang disusun untuk panduan kelas misiologi STT Real Batam. Namun, buku ini diharapkan juga bisa menjadi berkat bagi masyarakat gereja dan praktisi misi secara umum. Tulisan dalam buku ini dibuat bukan hanya berdasarkan teori, melainkan juga data-data dari berbagai sumber dan fakta di lapangan yang sudah dijalani penulis sebagai Hamba Tuhan yang memulai pelayanan sepenuh waktu sejak 9 September 1997 sampai sekarang. Penulis adalah praktisi misi sampai hari ini. Ia telah menanam lebih dari 150 gereja regular, baik dalam negeri maupun luar negeri. Ia telah mengutus misionaris sejak 2006. Penjangkauan (unreached people group dan cross cultural mission). Perjalanan misi tersebut telah mengantar penulis keliling Indonesia dan bangsa-bangsa (kurang lebih 62 negara di lima benua). Dari praktisi misi, ia menjadi gembala gereja misi pada 2004 (GBI My Home Tanjung Pinang) dan saat ini menjadi akademisi Ketua STT Real Batam 2012 sampai sekarang. Pengalaman-pengalaman pribadi juga dituangkan dalam tulisan dalam buku ini. Tentulah buku ini diharapkan bisa menjadi berkat. 


\section{MISIOLOGI}

Dalam kesempatan ini, penulis juga ingin berterima kasih untuk keluarga, keluarga besar, jemaat yang dipimpin, seluruh staf struktural STT Real Batam yang mendukung pelayanan dan mendorong sehingga buku ini bisa dibuat.

Terima kasih juga untuk Pdt. Dr. Niko Njotorahardjo, gembala pembina senior yang selalu memberi visi dan tuntunan (Jakarta); Pdt. Djohan Handojo, mentor dan bapak rohani (BCS Singapura); Pdt. Nelson Matheus Sembiring (Melaka, sahabat dalam masa sulit dan pelayanan mula-mula sampai hari ini), rekan-rekan senior dalam ladang misi dan pengembalaan, ketaatan dan kesetiaan yang tidak diragukan, murah hati: Winson Hermanto Simamora (Kuala Lumpur); Joni Gultom (Ipoh Perak), Wempi Manuhutu (Pulau Penang); Daniel Ginting (Kuching Sarawak); Mulyadi (Atambua); Sapto Nainggolan (Vietnam); Waty Gultom (Davao Filipina); Eny (Kamboja yang saat ini sedang menunggu pengutusan tempat baru); Bennie Liebertus (Timor Leste); Yuniarti Rachel (Balikpapan, pendoa syafaat yang setia); Arie Suhernani (Timor Leste); Petrus Ng (Surabaya, sahabat sepenangungan); Erwin M. Widjaja (Batam, adik kandung dan sahabat, pendukung pelayanan yang bisa diandalkan); Olga Siahaan (Tanjung Balai Karimun [pemikir dan eksekutor yang handal]); Anen Kris (Tanjung Pinang, sahabat setia dan penopang pelayanan My Home); Sabar Hutagalung (Kijang, pekerja lapangan yang ulet); Ronal Sianipar (Anambas, pekerja yang bisa diandalkan); Matius Kurniawan; (Tanjung Pinang, sahabat, teman berbagi di GBI My Home); Rikson Situmorang (Tanjung Pinang, pemikir dan "silent supporter" yang luar biasa) dan semua tim "Cool 1" Tanjung Pinang serta semua sahabat yang tidak dapat saya sebutkan satu per satu. Kalian semua sangat berarti bagi saya. 
Last but not least, dua wanita yang memengaruhi hidup saya: Mama Teresia Yusniati, pendoa dan mama yang luar biasa. Lyna Sendy, belahan jiwa dan pendamping setia yang telah memberi dua belahan hati, yaitu: Joshua York Widjaja dan Caleb Syeda Widjaja; pendamping dari masa susah, sulit dan bahagia sampai hari ini dan selamanya.

Penulis 


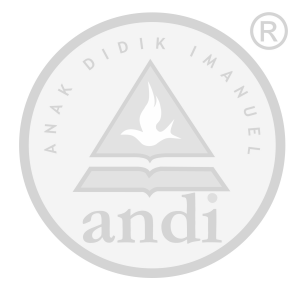




\section{Misi dalam Perjanjian Lama dan Perjanjian Baru'}

\section{Misi dalam Perjanjian Lama dan Perjanjian Baru: Kesinambungan}

Misi dan pemuridan merupakan hal yang tidak terpisahkan dalam tugas pelayanan gereja. Sejak Perjanjian Lama, tugas misi telah ada dan dapat dilihat dari sudut pandang panggilan dan pengutusan Israel. Israel dipanggil sebagai bangsa yang mengemban tugas untuk menyatakan Allah kepada bangsabangsa lain. Sedangkan pemuridan, dalam konteks Perjanjian Lama harus dilihat sebagai proses keberlanjutan dari misi. Panggilan Allah atas Israel berkaitan dengan pemuridan (praksis pendidikan). Hal ini dapat dilihat dalam perealisasian panggilan Allah atas bangsa Israel untuk hanya menyembah satu Allah, Allah yang Esa seperti yang ada dalam Ulangan 6:4.

Pemuridan merupakan proses pendidikan (agama) yang bersumber dari Allah dan ditugaskan kepada Israel (PL: Allah

1 Tulisan ini sumbangsih dari dosen dosen STT Real Batam: Noh Boiliu, Otniel Harefa, Irfan Simanjuntak, Sakphin Prokorus. 


\section{MISIOLOGI}

kepada Israel), murid-murid Tuhan Yesus dan gereja (PB: Kristus kepada para rasul-Nya dan kepada gereja sebagai tubuh-Nya). Dalam Perjanjian Lama, sumber epistemologinya bersumber dari Allah yang merupakan sumber dan hakikat pendidikan sehingga persoalan moralitas menjadi dasar dari pengajaran yang dimaksud. Dengan hanya merujuk kepada Allah, Allah menjadi rujukan sumber moral. Dengan demikian, dapat dikatakan misi bermuara kepada pemuridan dan pemuridan kepada misi. Tidak ada misi yang meniadakan pemuridan sebagai proses mendidik umat mengenal Tuhan secara pribadi dan mendalam yang pada akhirnya akan menyatakan kembali pribadi Tuhan kepada orang lain.

Dalampengertianini,gerejatidakbolehhanyamenekankan misi dan meniadakan pemuridan atau menekankan pemuridan dan meniadakan misi. Atau tidak menekankan keduanya. Gereja dipanggil untuk tugas misi, sama seperti Allah memanggil Israel dan Kristus memilih para rasul dan membentuk gereja sebagai tubuh-Nya. Dia memang mengejewantahkan tugas misi dan pemuridan kepada para rasul dan gereja.

Memahami posisi bangsa Israel dalam peta visi Allah atas dunia merupakan pintu masuk untuk lebih memahami kehendak Allah atas gereja. Urgensitas pemahaman kita atas posisi Israel dalam peta visi Allah adalah agar gereja Tuhan mengerti maksud pemanggilan, penetapan, dan pengutusan Tuhan atas Israel; mengerti reaksi dan aksi Israel dalam menjalani misi tersebut. Hal ini perlu untuk memberi kerangka dasar pemikiran bagi misi gereja. Memahami panggilan Allah atas Israel merupakan langkah awal dalam memahami peta misi Allah sebab "from Genesis to Malachi Jehovah is portrayed as a missionary God. The Jesus of the New Testament is the Jehovah of the Old. He was the first and 
great Missionary..." Perintah misi berkaitan dengan cara manusia tetap berada dalam hubungan dan komunikasi dengan Allah. Allah memanggil Israel-dan selanjutnya gereja-agar yang terputus hubungannya dengan Allah dapat mendengar berita misi dan kembali membangun hubungan dengan Allah. Hal itu karena sejak awal, Allah menciptakan manusia untuk diri-Nya. Sebagaimana Kane berkata, "Man was created in the beginning not only by God but for God."

Menurut Kane ada tiga tujuan pilihan Allah atas Israel saat kita melihatnya dalam konteks misi, yakni "first, Israel was to be the recipient and guardian of God's special revelation to the world (Heb. 1:1-3). Second, Israel was to be the channel through which the Redeemer was to enter the stream of human history. Third, Israel was to be God's servant and witness in the midst of the nations." "Tujuan ini, demikian Harold Cook berpendapat, juga berkaitan dengan sepuluh hukum Allah (the ten commandments) sebagai bukti legal (legalitas itu dapat dilihat melalui adanya tempat diberikan dan 10 hukum itu sendiri) bahwa Allah telah memilih dan mengutus mereka bahkan Allah pernah berbicara kepada mereka. ${ }^{5}$

Awalnya, panggilan itu tidak terlalu dimengerti oleh Israel. Saat masih berada di Mesir misalnya, Israel pada umumnya hanya mengarahkan pandangannya pada cara memperoleh kemerdekaan dari Mesir. Bahkan saat Musa menyampaikan visi Tuhan atas mereka tentang tanah Kanaan sebagai tujuan

2 J. Herbert Kane, The Christian World Mission: Today and Tomorrow (Michigan: Baker Book House, 1986), hal.16.

3 Ibid.

4 Ibid, hal.27.

5 Harold R. Cook, An Introduction to Christian Missions(Chicago: Moody Press, 1974), hal 61. Cook juga mengatakan bahwa misi dapat ditemukan dalam Pentateukh (hal. 59), Mazmur (hal. 61), dan nabi-nabi (hal. 62). 


\section{MISIOLOGI}

mereka, mereka hanya mengerti berita tersebut sebatas "bebas dan memiliki negeri." Pandangan semacam ini tentu akan mengarahkan mereka hanya pada keinginan sebatas memiliki negeri sendiri sehingga mereka menjadi setingkat dengan bangsa-bangsa lain di sekitarnya. Tidak lebih dari itu.

Pemikiran Israel tersebut dapat ditelusuri dari sikap dan reaksi mereka ketika Musa menyampaikan visi tersebut untuk pertama kalinya. Bahkan sikap dan reaksi lainnya dapat ditelusuri ketika terjadi proses keluar dari Mesir, memasuki Kanaan dan menetap di Kanaan.Umumnya Israel menafikan panggilan Allah atas mereka sebagai misionaris. Penafian tersebut dapat dilihat dari sikap mereka untuk tidak terpaut kepada Tuhan, tegar tengkuk, dan lain-lain. Sikap-sikap ini menunjukkan bahwa mereka tidak memiliki tanggungjawab misi atau tidak melihat posisi mereka sebagai misionaris Tuhan di tengah-tengah bangsa-bangsa lain.

Sesungguhnya melalui mandat misi Allah kepada Israel, kita dapat mengerti konsep misi alkitabiah. Konsepnya adalah setiap orang yang belum mengenal Allah baik dalam konteks Perjanjian Lama maupun Perjanjian Baru harus mengenalnya melalui Israel (PL) dan melalui gereja Tuhan (PB). Wilayahnya meliputi seluruh dunia, yakni yang belum mengenal dan menerima Tuhan (Kristus).

Israel dalam Perjanjian Lama dan gereja di Perjanjian Baru, sama-sama mengemban tugas sebagai misionaris. Hal ini berarti bahwa mereka harus melaksanakan mandat. Dalam konteks Perjanjian Lama, tidak ada keharusan untuk menjadi warga Israel sebagai representasi berada dalam "Tuhan," melainkan ditunjukkan melalui sikap tunduk dan menyembah hanya kepada YHWH. Sedangkan di Perjanjian Baru, memang tidak 
ada keharusan untuk berada dalam gereja, tetapi merupakan hal yang tidak mungkin mengenal Allah dan menandai-Nya jika tidak dalam gereja. Hal ini berarti memang tidak ada jaminan bahwa yang berada dalam gereja "pasti selamat," sejalan dengan itu juga tidak mungkin ada jaminan pengajaran yang benar jika tidak "dalam gereja".

Dengan demikian, konsentrasi dari tulisan ini adalah misi bukanlah tugas pertama dan terakhir melainkan misi ada dalam proses menjadi milik Kristus seutuhnya, yakni yang telah mengenal Allah (Kristus, baik PL maupun PB) yang di pundaknya tugas misi diletakkan. Hal ini berarti semua orang percaya dapat dikatakan adalah misionaris. Proses selanjutnya adalah menjadikan semua murid Kristus, yakni yang telah mengenal dan menerima Kristus.

\section{A. Tinjauan Umum Misi dalam Perjanjian Lama}

Ada kesalahpahaman yang populer bahwa Perjanjian Lama (PL) tidak memiliki mandat misi dan bahwa Perjanjian Lama adalah kitab yang didedikasikan hanya bagi orang Yahudi dan sejarah Yahudi. Namun, pandangan tersebut tidak sesuai dengan klaim yang dibuat oleh Perjanjian Lama itu sendiri. Bahkan, jika membatasi penyelidikan kita kepada tiga teks kunci dalam Perjanjian Lama-yang akan dibahas di bagian selanjutnya nanti, kita akan langsung dapat melihat bahwa ketiga teks ini menghadirkan beberapa pernyataan panggilan misi paling kuat yang bisa ditemukan di mana pun di Alkitab.

Jika memahami misi dalam pengertian yang hanya berkaitan dengan upaya untuk mengirim misionaris ke tempat yang belum terjangkau Injil, Perjanjian Lama memang tidak mengajarkan hal yang demikian. Sebagaimana Bosch mengata- 


\section{MISIOLOGI}

kan, "If we adhere to the traditional understanding of mission as the sending of preachers to distant places... there is, in the Old Testament, no indication of the believers of old covenant being sent by God to cross geographical, religious, and social frontiers in order to win others to faith in Yahweh."' Perjanjian Lama jelas belum menempatkan penugasan orang Israel melakukan pekabaran ke luar dari teritori mereka menuju ke segala bangsa sebagai perintah yang tegas. Kalau pun ada (seperti perintah kepada Yunus untuk pergi ke Niniwe, yang dianggap sebagian orang sebagai satu-satunya ajaran tentang misi dalam PL), hal tersebut tidak dilihat sebagai panggilan misi (terutama dalam kacamata Yunus sebagai penerima perintah tersebut sebab Yunus justru lebih suka orang Niniwe dihukum dan dibinasakan Tuhan).

Bahkan saat Perjanjian Lama berbicara tentang hubungan Israel dengan bangsa-bangsa lain, Perjanjian Lama justru terkesan memberi penilaian yang negatif. Israel dilarang berhubungan dengan bangsa-bangsa lain. Hubungan-hubungan tersebut digambarkan sebagai merusak dan berdampak buruk bagi iman dan ibadah mereka. Allah kadang digambarkan terlibat berperang melawan bangsa-bangsa di sekitar Israel. Itulah sebabnya pemisahan diri Israel dari bangsa-bangsa lain terkesan disarankan. Hal-hal inilah yang pada akhirnya menyebabkan banyak orang menyimpulkan bahwa Perjanjian Lama tidak mengajarkan konsep misi.

Akan tetapi, jika Perjanjian Lama diselidiki dengan tekun, akan terlihat ada "hari depan" untuk semua bangsa di dunia. Dalam Perjanjian Lama-dan juga Perjanjian Baru,

6 David J. Bosch, Transforming Mission: Paradigm Shifts in Theology of Mission (Maryknoll, NY: Orbis Book, 1994), hal. 17. 
Allah merencanakan keselamatan bagi dunia ini. Dalam rencana tersebut, Dia tidak hanya memerhatikan satu bangsa saja, yaitu Israel, melainkan segenap umat manusia di bumi. Venema berkata: "mulai dari halaman pertama sampai halaman terakhir, Alkitab memerhatikan dunia seanteronya." Itulah sebabnya, berikut akan disajikan secara singkat ajaran misi yang dikandung Perjanjian Lama. ${ }^{8}$

\section{Kitab-kitab Taurat}

Sejak awal kitab Kejadian, motif misi sudah diperlihatkan. Pesan dalam pasal-pasal terawalnya sudah menunjukkan bahwa Allah bertindak secara universal bagi kesejahteraan dan keselamatan manusia ciptaan-Nya. Pesan-pesan ${ }_{\mathbb{R}}$ itu ruang lingkupnya universal dan audiensnya global. Merupakan konsensus bahwa Kejadian pasal 1-11 diarahkan kepada segenap umat manusia atau merujuk pada sifat universalisme. Janji yang mendahului, demikian de Kuiper: "Firdaus, persekutuan dengan Allah, damai di bumi (Kej. 9), dan penyebaran bangsa-bangsa di seluruh bumi (Kej. 10)." Hal ini semua menunjukkan rencana Allah yang ingin berhubungan dengan semua umat manusia yang Ia ciptakan dan kerinduan-Nya agar semua manusia menerima anugerah-Nya yang menyelamatkan. Walaupun akhirnya dalam Kejadian 3 terjadi peristiwa kejatuhan dalam dosa, catatan

7 H. Venema, Injil untuk Semua Orang: Pengantar ke dalam Ilmu Misiologi (Jakarta: YKBK, 2006), hal. 87.

8 Pembagian akan dilakukan mengikuti urutan Alkitab PL Ibrani yang disebut TANAKH (Torah, Nebiim dan Ketubim atau Kitab Taurat, Kitab Para Nabi, dan Kitab Tulisan-tulisan). Urutan ini dipilih karena bersifat sederhana dan cocok dengan ruang yang terbatas dalam buku ini untuk meninjau perkembangan konsep misi dalam keseluruhan PL secara lengkap.

9 Arie de Kuiper, Missiologi (Jakarta: BPK Gunung Mulia, 2013), hal. 18. 


\section{MISIOLOGI}

yang indah muncul di ayat 15 . Ayat ini merupakan salah satu ayat terpenting dalam memahami misi di Perjanjian Lama. Di dalamnya Allah menjanjikan bahwa keturunan perempuan akan menghancurkan sang Ular. Para sarjana Kristen memahami hal ini sebagai protoevangelium, kemunculan cahaya Injil untuk pertama kalinya. Melalui janji tersebut, Allah mengumumkan akan memberikan jalan keselamatan kepada semua manusia melalui "keturunan perempuan" itu. Keselamatan itu tidak memiliki batasan etnik atau bangsa karena tepat diberikan setelah Adam jatuh dalam dosa.

Akibat kejatuhan, manusia berkali-kali gagal dalam mengikuti rencana Tuhan. Pembunuhan Habel oleh Kain, air bah, atau menara Babel menjadi bukti nyata kegagalan manusia. Inilah yang menjadi latar belakang pemanggilan sekaligus alasan pemilihan Abraham (Kej. 12:1-3). Melalui pemilihan ini, kita tahu bahwa Allah memakai cara berbeda dalam berhubungan dengan manusia. Kegagalan-kegagalan di pihak manusia menyebabkan Allah memilih satu jalur keselamatan yang secara khusus terfokus kepada Abraham. Namun, hal ini tidak berarti Allah membuang manusia lainnya. Justru melalui Abraham dan keturunannya, seluruh kaum di muka bumi akan diberkati. Fokus utama dari pemilihan itu bukan saja agar Abraham dan keturunannya diberkati, melainkan hal yang akan Allah lakukan terhadap manusia melalui mereka: Abraham dan keturunannya akan menjadi sarana atau saluran keselamatan bagi seluruh umat manusia.

Motif pemanggilan Abraham tersebut digenapi dan diteruskan melalui pemilihan Israel yang merupakan keturunan Abraham. Dalam pemilihan Israel, rencana Allah pada masa 
mendatang bagi mereka, dan peran yang akan mereka jalankan dalam rencana-rencana-Nya, tidak kurang dari janji yang telah diberikan kepada Abraham (bnd. Kel. 19:3-6). Hal ini berarti, sama seperti Abraham, Israel juga dipanggil untuk menjadi saluran berkat bagi bangsa-bangsa lain. Dengan pemilihan mereka, Allah tidak membuang bangsa-bangsa lain, melainkan akan diberkati melalui Israel, baik melalui hal yang Israel lakukan sebagai umat pilihan maupun melalui hal yang Tuhan kirimkan melalui Israel: dari keturunan Abraham akan lahir Juruselamat dunia, Yesus Kristus..$^{10}$ Dengan demikian, Israel dipilih bukan untuk keutamaan mereka, melainkan untuk keutamaan Tuhan. Ia memilih mereka karena anugerah dan bertujuan agar rencana keselamatan-Nya tergenapi. Sebagaimana Bavink mengatakan: "If Jehovah is God of Israel because He has made a covenant with Israel, it is conceivable that other nations will also some day be included in that covenant. For Israel has no individual and peculiar claim upon God. Its privileged position is due to God's electing grace."11 Allah memang berencana untuk menjangkau semua bangsa dan Israel adalah pelayan Allah bagi bangsa-bangsa tersebut. Itulah hakikat pemanggilan dan pemilihan mereka.

\section{Kitab-Kitab Nebiim (Nabi-nabi)}

Motif misi dalam kitab para nabi sangatlah terasa. Salah satu yang mendasar adalah janji Allah kepada Daud (2 Sam. 7). Dalam perjanjian tersebut, Allah menjanjikan untuk membangun bagi Daud sebuah dinasti dan kerajaan yang kekal, di mana keturunannya akan memerintah selamanya.

10 Venema, Injil untuk Semua Orang, hal.99.

11 J.H. Bavink, An Introduction to the Science of Mission (New Jersey: P\&R Publishing, n.d), hal. 13. 


\section{MISIOLOGI}

Mayoritas ahli sepakat bahwa janji itu mengacu kepada Mesias karena faktanya dinasti Daud sempat terputus dari takhta Israel ketika Yerusalem dihancurkan oleh tentara Babel. Sang Mesias, putra Daud itu, pada akhirnya akan berkuasa di takhta Daud dan menjadi penguasa eskatologis yang membawa damai dan menggenapi rencana Allah bagi Israel dan bangsa-bangsa. Dengan demikian, perjanjian dengan Daud ini erat kaitannya dengan janji kepada Abraham dan Israel. Kostenberger merangkumkan dengan baik hubungan ketiganya: "The covenant with David looks back to the divine intention for Israel through Sinai. At the same time, this covenant is intimately linked with God's saving purposes for humankind through Abraham, and thus to the reversal of the disastrous consequences of the fall in Genesis 3-11. It will be through Davidic king who function as Yahweh's vicegerent that the latter's rule over the nations will be exercised. The ultimate fulfiller of this role is Jesus of Nazareth who, as son of David, was son of Abraham, and also Son of God."12 Oleh karena itu, kehadiran Mesias ini tidak hanya akan memberkati Israel, tetapi juga bangsa-bangsa lain.

Tema pemerintahan Mesias ini merupakan berita yang konstan disampaikan para nabi. Ia digambarkan sebagai poros atau pusat berkisarnya zaman yang akan datang. Zaman itu akan ditandai dengan terlaksananya pemerintahan Allah atas Israel dan bangsa-bangsa lain. Peran signifikan dari Mesias adalah pemerintahan Allah itu akan didatangkan dan dilaksanakan oleh oknum mesianis sebagai penyelamat. ${ }^{13}$ Dalam pemerintahannya, Dia digambarkan memerintah dengan adil dan damai (bnd. Yes.

12 Andreas J. Kostenberger dan Peter T. O'Brien, Salvation to the Ends of the Earth (Downer Grove, IL: Intervarsity Press, 2001), hal. 40.

13 de Kuiper, Missiologia, hal. 24. 
9:6; 11:1, 10; Yer. 23:5-6; Yeh. 34:23; Mi. 5:1-5; Hag. 2:23; Za. 9:910). Segala bangsa akan tunduk dan diberkati olehnya.

Selain peran penting Mesias, tema yang tidak kalah penting adalah visi tentang keselamatan yang pada akhirnya akan menjangkau bangsa-bangsa. Dalam konteks yang paralel dengan keberadaan Mesias, bangsa-bangsa dikatakan akan berkumpul di Sion (Yes. 2:2-4; Yes. 60-62; bnd. Mi. 4:1-5). Sion akan menjadi pusat dari dunia yang baru (Yes. 35:1-10; 65:1718). Bangsa-bangsa akan meninggikan panji-panji Mesias (Yes. 11:10) dan mengadakan ziarah ke Yerusalem dalam rangka untuk belajar tentang Allah dan jalan-jalan-Nya (Yes. 2:2-3; Za. 8:20-23; Mi. 4:1-2). Kedatangan mereka ke Yerusalem akan bersamaan dengan kepulangan keturunan Yakub yang sebelumnya terpencar (Yes. 60:2-9). Israel pada masa itu juga akan dipulihkan dan diselamatkan (Yer. 31:31-34). Bangsabangsa itu akan menyembah Allah karena mereka saat itu akan menjadi umat-Nya (Za. 2:11) dan mengambil bagian dalam keselamatan-Nya yang bersifat universal.

Dengan demikian, dapat dikatakan bahwa para nabi memiliki pandangan serupa akan masa depan. Keselamatan tidak hanya akan diterima oleh Israel saja. Oleh anugerah-Nya yang penuh belas kasihan, bangsa-bangsa di bumi juga akan menikmati keselamatan itu melalui kehadiran sang Mesias yang berasal dari keturunan Daud, raja orang Israel.

\section{Kitab-kitab Ketubim (Tulisan-tulisan)}

Senada dengan bagian-bagian yang lain dalam Perjanjian Lama, bagian yang dalam bahasa Ibrani disebut Ketubim ini menjabarkan misi dalam hubungannya dengan rencana Allah 


\section{MISIOLOGI}

menghadirkan keselamatan bagi semua bangsa di muka bumi. Pada akhirnya, semua kaum di muka bumi akan mendapat berkat (bnd. Kej. 12:1-3). Salah satu kitab yang menegaskan hal tersebut adalah kitab Mazmur. Tanpa mengabaikan kitab-kitab lain yang juga penting, patut dicatat bahwa kitab Mazmur menempatkan posisi bangsa-bangsa dalam rencana keselamatan Allah sebagai isu yang penting.

Tidak dapat disangkal bahwa di dalam kitab Mazmur, posisi Israel sebagai bangsa pilihan ditegaskan. Israel adalah bangsa yang berbahagia karena merupakan umat dari Tuhan Allah (Mzm. 33:12) yang memiliki kedudukan yang istimewa di hadapan Tuhan dan bangsa-bangsa lain. Mereka adalah milik kepunyaan Tuhan (Mzm. 50:7). Tuhan hanya memberitakan firman, ketetapan dan hukum-hukum-Nya kepada Israel dan bukan kepada bangsa-bangsa lain (Mzm. 147:19-20). Namun dibalik posisi istimewa ini, Israel juga selalu disadarkan bahwa kejahatan mereka akan diperhitungkan sama dengan bangsabangsa lain (Mzm. 14, 53) dan keistimewaan mereka tidak berdasarkan pada keunggulan atau kebaikan mereka, tetapi pada anugerah Tuhan.

Dalam keistimewaan Israel tersebut, terdapat penegasan bahwaSion merupakan pusat dunia (Mzm. 87 dan 48). Dalamkitab Mazmur, Allah dikatakan berkenan memilih Sion sebagai tempat kehadiran-Nya (Mzm. 50:2). Di Sion, orang-orang akan diberkati (Mzm. 36:8-9). Hal yang menarik, Pemazmur tidak membatasi keistimewaan Sion hanya pada bangsa Israel. Sion dikatakan akan menjadi pusat kegirangan seluruh bumi (Mzm. 48:3). Bahkan seolah-olah bernubuat, Pemazmur mengatakan bahwa Sion akan melahirkan orang-orang bahkan bangsa-bangsa yang mendapat hak menjadi anggota-anggota umat Tuhan (Mzm. 
87:5-6). ${ }^{14}$ Hal ini berarti keberadaan Sion menempati posisi yang sangat penting dalam rencana keselamatan Allah. Israel dan juga bangsa-bangsa lain pada akhirnya akan menyadari signifikansi Sion dalam keselamatan mereka.

Dengan demikian, kitab Mazmur secara tegas mengatakan bahwa Tuhan tidak mengabaikan bangsa-bangsa di luar Israel. Dia dikatakan memerhatikan semua pekerjaan anak manusia (Mzm. 33:13-15). Banyak kali Tuhan diungkapkan dalam sebuah kekuasaan yang bersifat universal, melingkupi seluruh dunia: Dia adalah pencipta langit dan bumi, pemilik segala ciptaanNya, pemelihara ciptaan-Nya, raja dunia ini, hakim yang adil dan satu-satunya Allah. ${ }^{15}$ Bahkan dalam Mazmur 67, secara jelas diungkapkan maksud agar berkat Allah mengalir ke seluruh bangsa-bangsa. Hal ini menunjukkan bahwa, dalam kitab Mazmur, bangsa-bangsa yang percaya kepada Yahweh melalui pemerintahan sang Mesias (bnd. Mzm. 2) akan diselamatkan dan datang ke Sion untuk menyembah Tuhan. Hal itu artinya, keistimewaan Israel tidak menyebabkan bangsa-bangsa lain terputus dari rencana Allah untuk menyelamatkan seluruh manusia. Justru Israel ada sebagai sarana untuk keselamatan bangsa-bangsa.

\section{B. Karakter Misi Perjanjian Lama}

Misi dalam Perjanjian Lama bersifat sentripetal, yaitu dari luar ke dalam. Maksudnya adalah bangsa-bangsalah yang datang ke bangsa Israel sehingga mereka mengenal dan menyembah Allah

14 de Kuiper, Missiologia, hal. 23.

15 Ajaran-ajaran tentang peran dan kedudukan Allah atas bangsa-bangsa seperti yang diajarkan kitab Mazmur ini diuraikan dengan baik oleh Venema. Lihat Venema, Injil untuk Semua Orang, hal. 112-116. 


\section{MISIOLOGI}

Israel. Misi yang bersifat sentripetal ini tertulis dalam Yesaya 60:3: "Bangsa-bangsa berduyun-duyun datang kepada terangmu, dan Raja-raja kepada cahaya yang terbit bagimu," dan Yesaya 62:2: "Maka bangsa-bangsa akan melihat kebenaranmu dan akan menyebut engkau dengan nama baru yang akan ditentukan oleh TUHAN sendiri."

Bahkan Nabi Yesaya dalam Yesaya 2:2, menempatkan gunung Sion sebagai gunung suci, pusat bumi dan penting bagi seluruh dunia. Oleh karena gunung Sion adalah Rumah Tuhan, maka: "Segala bangsa-bangsa akan berduyun-duyun ke Sion."

Dalam pemberitaan para nabi selalu saja ada pengharapan bahwa bangsa-bangsa lain akan ditarik menuju pusat kehadiran Allah Israel, lalu bangsa-bangsa lain itu akan mengaku namaNya. Keselamatan eskatologis digambarkan dalam Perjanjian Lama melalui gambaran tentang datangnya bangsa-bangsa lain berarak-arakan ke arah Sion. Kedatangan itu merupakan gerakan yang sentripetal, menuju pusat tempat tersedia keselamatan, ada Allah dan umat-Nya, pusat kehadiran-Nya, pusat dunia. Bangsa-bangsa akan datang kepada Israel dan Allahnya.

Misi dalam Perjanjian Lama bukanlah Israel yang bertindak, bukan pula bangsa-bangsa yang bertindak tetapi Allah sendirilah yang bertindak terhadap Israel dalam pusat sejarah dan pusat dunia, dan dengan jalan demikian segala bangsa akan datang untuk melihat dan akhirnya untuk disangkut-pautkan dalam drama keselamatan. Di sini bukanlah Israel yang menjadi saksi, tetapi bangsa-bangsa akan menyaksikan hal yang terjadi di Israel sehingga ada ketertarikan untuk mencari Allah Israel.

Dari hal yang dibahas di atas jelas terlihat bahwa misi dalam Perjanjian Lama bersifat sentripetal. Di Israel tidak ada pengutusan misionaris untuk menyampaikan kabar keselamatan 
kepada bangsa-bangsa lain. Sebaliknya, bangsa-bangsalah yang datang kepada Israel.

Dengan demikian, dapat dikatakan bahwa Perjanjian Lama tidak berisi tindakan misi yang dilakukan Israel, tetapi Perjanjian Lama adalah rencana misi Allah. Sejalan dengan itu Peters mengatakan bahwa "Perjanjian Lama adalah buku misi." ${ }^{16}$ Oleh karena itu, sangatlah penting memahami rencana agung Allah bagi pekerjaan misi dalam Perjanjian Lama. Berikut pemaparan tentang rencana misi Allah dalam Perjanjian Lama:

\section{Allah adalah Allah yang mengarahkan sejarah untuk tujuan menyelamatkan manusia}

Sejarah bukanlah aliran kejadian acak yang terjadi secara kebetulan. Dengan mempelajari sejarah terlihat dengan jelas akan adanya satu jalan cerita yang dalamnya ada pribadi yang mengendalikannya. Setiap peristiwa terjadi dengan tujuan yang jelas. Sebagai orang yang percaya kepada Allah, orang Kristen menyadari semuanya itu dikendalikan oleh Tuhan. Dalam ruang dan waktu, Tuhan sedang mengerjakan rencana yang disusunNya dalam kekekalan masa lalu dan akan diwujudkan-Nya dalam kekekalan masa depan. Allah adalah pemberita kabar baik yang pertama kepada manusia yang telah jatuh dalam dosa. ${ }^{17}$

Seluruh rencana-Nya terpusat pada rencana pemulihan ciptaan-Nya yang istimewa, yaitu manusia yang telah hancur karena dosa, yang karenanya pemulihan manusia ini akan menghasilkan pemulihan seluruh ciptaan.

16 David R. Brougham, Merencanakan Misi Lewat Gereja-Gereja Asia (Malang: Gandum Mas), hal. 13.

17 M. David Sills, Panggilan Misi (Surabaya: Momentum, 2011), hal. 45. 


\section{a. Dia memilih satu orang tetapi pada saat yang sama Dia memikirkan semua bangsa}

Abraham sangat memahami hal yang terkandung dalam panggilannya yang dibuktikan dengan ketaatannya kepada perintah Allah.18 Janji Tuhan kepada Abraham adalah: "Berfirmanlah TUHAN kepada Abram: Pergilah dari negerimu dan dari sanak saudaramu dan dari rumah bapamu ini ke negeri yang akan Kutunjukkan kepadamu; Aku akan membuat engkau menjadi bangsa yang besar, dan memberkati engkau serta membuat namamu masyhur; dan engkau akan menjadi berkat. $\mathrm{Aku}$ akan memberkati orang-orang yang memberkati engkau, dan mengutuk orang-orang yang mengutuk engkau, dan olehmu semua kaum di muka bumi akan mendapat berkat" (Kej. 12:1-3). Menurut Soot, janji Allah pada Abraham dapat dibagi dalam tiga bagian, yaitu:

\section{- Negeri: yang akan ditunjukkan}

Sebuah janji akan adanya daerah kekuasaan Abraham dan akan diwariskan kepada keturunannya. Hal ini memberikan penegasan bahwa melalui Abraham Tuhan mau menghimpunkan bangsa-bangsa dalam satu daerah kekuasaan Allah melalui Abraham.

\section{- Keturunan: menjadi bangsa yang besar}

Allah memberkati Abraham dengan keturunan yang akan menjadi bangsa yang besardengantujuan memengaruhi bangsa lain agar menyembah Allah Abraham.

18 Nely P. Tuhumury, Utuslah Aku, ed., Daniel Ronda (Bandung: Kalam Hidup,2012), hal. 117. 


\section{- Berkat: melimpah sampai ke semua bangsa}

Abraham diberkati dengan sangat melimpah oleh Tuhan dengan maksud memperkenalkan diri-Nya kepada bangsa-bangsa agar menyembah dan percaya kepada Tuhan Allah yang disembah dan dilayani oleh Abraham. Tuhan tidak memanggil Abraham untuk kepentingan Abraham, tetapi pandangan ke depan, yakni demi umat manusia. ${ }^{19}$ Tuhan ingin memberi berkat dan keselamatan kepada semua ras dan bangsa melalui satu orang, dari benih dan keturunannya. Jadi, janji-janji Allah kepada Abraham mempunyai tujuan umum. Anak AbrahamIshak, mewarisi janji ini, kemudian Yakub (Kej. 26:4; 28:14), lalu Yehuda (Kej. 49:10). Warisan untuk memberkati bangsa-bangsa bergerak melalui keturunan Abraham.

\section{b. Ia memilih satu bangsa untuk memberkati bangsa-bangsa}

Setelah memilih Abraham, Allah meneruskannya dengan membangkitkan bangsa yang istimewa. Bangsa tersebut mewarisi panggilan yang dipercayakan Tuhan pada Abraham. Melalui keturunan Abraham, semua kaum di muka bumi akan diberkati. Firman Tuhan mengatakan:

"Aku bersumpah demi diri-Ku sendiri-demikianlah firman TUHAN-: Karena engkau telah berbuat demikian, dan engkau tidak segan-segan untuk menyerahkan anakmu yang tunggal kepada-Ku, maka Aku akan memberkati engkau berlimpahlimpah dan membuat keturunanmu sangat banyakseperti bintang di langit dan seperti pasir di tepi laut, dan keturunanmu itu akan menduduki kota-kota musuhnya. Oleh keturunan-

19 Tuhumury, Utuslah Aku, hal. 117. 


\section{MISIOLOGI}

mulah semua bangsa dibumi akan mendapat berkat, karena engkau mendengarkan firman-Ku" (Kej. 22:16-18).

Panggilan misi Israel (sebagaimana telah disinggung dalam bagian sebelumnya) terdapat dalam tiga teks dasar dalam Perjanjian Lama (Kejadian 12:1-3, Keluaran 19:4-6, Mazmur 67). Dari ayat-ayat tersebut jelas terlihat tanggung jawab Israel untuk memberitakan pesan Tuhan kepada bangsa-bangsa lain.

Dalam Keluaran 19 misalnya, bangsa Israel mendapatkan tugas dari Allah untuk berfungsi bagi kepentingan Kerajaan Allah sebagai perantara (mediator) kepada bangsa-bangsa. Hal ini berarti Israel menjalankan dua hubungan: satu sisi kepada Allah, sisi yang lain kepada bangsa-bangsa. Mereka menjadi umat yang dikhususkan/dipisahkan bagi semua bangsa. Dari kitab Keluaran kita mempelajari cara Tuhan mengangkat bangsa Israel, dan mengingatkan bahwa merekalah pewaris-pewaris Abraham dan sekaligus pewaris janji Tuhan. Melalui mereka, Tuhan akan memberkati bangsa-bangsa. Melalui mereka, Dia akan menyampaikan rencana keselamatan-Nya sampai kepada suku bangsa di tempat yang paling terpencil sekalipun! Israel akan menjadi kerajaan imam dan bangsa yang kudus. George Peters mengingatkan bahwa Tuhan tidak saja memanggil bangsa Israel untuk menjadi umat-Nya, tetapi juga untuk menjadi hamba-Nya. ${ }^{20}$

Hak-hak istimewa yang mereka miliki, tentu bertautan dengan tanggung jawab yang unik pula. Mereka harus memancarkan kemuliaan Tuhan di antara bangsa-bangsa dan meski masih hidup di tengah bangsa-bangsa di dunia, mereka

20 Brougham, Merencanakan Misi Lewat Gereja-Gereja Asia, hal. 15. 
harus mengasingkan diri dalam hal mematuhi hukum-hukum Tuhan dengan sempurna.

Tujuan akhir Tuhan adalah agar bangsa-bangsa memuliakan Dia karena keselamatan dan berkat-Nya (Mzm. 67:34,7-8) dan supremasi kerajaan-Nya (Mzm. 67:4). Jadi jelaslah alasan Allah memilih bangsa yang kecil dan lemah seperti Israel. Hal itu semua untuk menunjukkan kepada bangsabangsa kekuasaan Allah melalui Israel, yang pada akhirnya semua bangsa akan menyembah Allah Israel dan menerima keselamatan dari pada-Nya. Jadi Perjanjian Lama menjunjung tinggi metode sentripetal, yang bisa diumpamakan sebagai magnet suci yang mempunyai daya tarik ke arah dirinya sendiri. Dengan menjalani kehidupan di hadirat Tuhan yang disertai rasa takut kepada-Nya, Israel mengalami berkat Tuhan. Dengan cara ini, bangsa Israel menjadi berkat untuk menjangkau bangsabangsa bagi Allah sehingga mereka tertarik kepada-Nya. Tuhan telah membentuk bangsa Israel untuk diri-Nya sendiri, untuk memberitakan kemasyhuran-Nya kepada bangsa-bangsa.

\section{c. Dia membangkitkan para nabi untuk menyuarakan rencana-Nya}

- Yeremia

Tuhan memanggil Yeremia untuk mejadi nabi bagi bangsa-bangsa. Melalui Yeremia Allah menyatakan isi hati-Nya agar semua bangsa mendengar firman-Nya dan berbalik kepada Allah dengan datang menyembah Allah. Melalui Yeremia, Allah menyatakan bahwa Dia memiliki rancangan damai sejahtera dan bukan kecelakaan (Yer. 11:29). Dengan demikian, Allah menegaskan bahwa Dia 
menghendaki keselamatan bangsa-bangsa yang mau datang kepada-Nya.

\section{- Yunus}

Isi hati Allah bagi upaya penyelamatan bangsa-bangsa juga terpampang dengan jelas melalui kisah Yunus yang umumnya dianggap sang misionaris Perjanjian Lama. Tuhan mengutusnya untuk berkhotbah di Niniwe, tetapi ia menolaknya dan lari ke Tarsus. Namun, Tuhan dengan segala cara mengembalikan Yunus pada panggilan-Nya untuk menyampaikan firman Allah pada orang-orang di Niniwe. Isi hati Allah jelas tertulis dalam Yunus 4:11: "Bagaimana tidak Aku akan sayang kepada Niniwe, kota yang besar itu, yang berpenduduk lebih dari seratus dua puluh ribu orang, yang semuanya tak tahu membedakan tangan kanan dari tangan kiri, dengan ternaknya yang banyak?" Pernyataan ini sangat jelas bahwa isi hati Allah adalah untuk menyelamatkan manusia karena itu Dia membangkitkan para nabi untuk melaksanakan maksud-Nya.

\section{Allah adalah Allah perjanjian dan berlimpah kasih karunia}

Tuhan yang penuh anugerah dan pemegang janji adalah Allah yang selalu menggenapi janji-Nya. Dia adalah Tuhan berkat. Perbuatan-Nya yang khas dan mendasar adalah memberkati umat dengan keselamatan (Kej. 12:2; Kis. 3:25-26). Tuhan juga adalah Tuhan yang penuh rahmat. Kelompok orang yang diselamatkan di surga merupakan kumpulan besar orang banyak yang tidak dapat terhitung banyaknya, dari segala bangsa dan 
suku dan kaum dan bahasa (Why. 7:9). Janji Tuhan ini sedang digenapi. Anak-cucu Abraham akan tidak dapat dihitung, banyaknya seperti debu tanah, bintang di langit, pasir di pantai.

\section{Tinjauan Umum Misi dalam Perjanjian Baru}

Para pujangga dan filsuf Yunani kuno merindukan masyarakat ideal dan memimpikan zaman keemasan yang hilang pada masa lampau. Namun, mereka tidak melihat kecemerlangan itu pada masa mereka atau pengharapan bahwa masa depan seperti itu dapat terjadi. Berbeda dengan itu, iman Ibrani-Kristen menyatakan pengharapannya dalam istilah Kerajaan Allah. Pengharapan alkitabiah ini tentunya tidak seperti mimpi para pujangga Yunani. Sebaliknya, pengharapan ini dinyatakan oleh Allah dan berakhir dalam Dia.

Ide alkitabiah tentang Kerajaan Allah berakar secara mendalam pada Perjanjian Lama. Ide tersebut didasarkan pada keyakinan bahwa ada satu Allah yang kekal dan hidup yang telah menyatakan diri-Nya kepada manusia. Allah tersebut juga telah menyatakan bahwa Dia memiliki tujuan bagi umat manusia yang telah dipilih-Nya untuk dicapai melalui Israel. Oleh karena itu, para nabi mengabarkan suatu hari ketika manusia akan hidup bersama dalam damai. Allah kemudian akan menjadi hakim antara bangsa-bangsa dan akan menjadi wasit bagi banyak suku bangsa. Oleh karena itu, mereka akan menempa pedang-pedangnya menjadi mata bajak dan tombak-tombaknya menjadi pisau pemangkas. Bangsa tidak akan lagi mengangkat pedang terhadap bangsa. "Ia akan menjadi hakim antara bangsabangsa dan akan menjadi wasit bagi banyak suku bangsa; maka mereka akan menempa pedang-pedangnya menjadi mata bajak dan tombak-tombaknya menjadi pisau pemangkas; bangsa tidak akan lagi 


\section{MISIOLOGI}

mengangkat pedang terhadap bangsa, dan mereka tidak akan lagi belajar perang" (Yes. 2:4).

Ketika masa itu tiba, masalah yang ada dalam masyarakat tidak hanya akan diselesaikan, tetapi kejahatan dalam lingkungan fisik manusia juga tidak akan ada lagi. Serigala akan tinggal bersama domba dan macan tutul akan berbaring di samping kambing. Anak lembu dan anak singa akan makan rumput bersama dan seorang anak kecil akan menggiringnya (Yes. 11:6). Damai, keamanan, kenyamanan-semuanya dijanjikan pada masa depan.

Kemudian, datanglah Yesus dari Nazaret dengan pengumuman ini, "Bertobatlah, sebab Kerajaan Surga sudah dekat!" (Mat. 4:17). Tema kedatangan Kerajaan Allah ini sentral dalam misi-Nya. Pengajaran-Nya dibuat untuk menunjukkan kepada manusia cara mereka bisa masuk dalam Kerajaan Allah (Mat. 5:20; 7:21). Pekerjaan Allah yang hebat dimaksudkan untuk membuktikan bahwa Kerajaan Allahtelah datang ke atas mereka (Mat. 12:28).

Berbagai perumpamaan Kristus mengilustrasikan kepada para murid-Nya kebenaran tentang Kerajaan Allah (Mat. 13:11). Ketika Dia mengajarkan para pengikut-Nya untuk berdoa, pada inti permohonan mereka ada kalimat, "datanglah Kerajaan-Mu, jadilah kehendak-Mu dibumisepertidiSurga” (Mat. 6:10). Menjelang kematian-Nya, Dia meyakinkan para murid-Nya bahwa Dia akan memberikan kebahagiaan pada mereka dan persekutuan dari Kerajaan Allah (Luk. 22:22-30). Dia berjanji bahwa Dia akan datang kembali ke bumi dalam kemuliaan untuk membawa berkat-berkat Kerajaan Allah bagi mereka yang sejak semula semua itu telah disediakan (Mat. 25:31, 34). 
Ketika kita berbicara tetang misi dan Perjanjian Baru, ${ }^{21}$ keduanya saling berkaitan. Dengan kata lain, Perjanjian Baru tidak dapat dilepaskan dari tindakan misi. Hal ini berarti orang percaya tidak dapat dilepaskan dari misi. Bahkan, "Christianity, if it is real Christianity, must of necessity be missionary...it is strange until we realize that many people's ideas Christianity have only a remote connection with the New Testament." ${ }^{22}$ Kekristenan, misi, dan pemuridan saling berkaitan.

Bahkan, Perjanjian Baru merupakan kelanjutan misi Allah di Perjanjian Lama. Allah memanggil Israel ke Kanaan karena Allah mempunyai tujuan atas Israel. Allah menetapkan Kanaan sebagai tujuan akhir perjalanan Israel. Mereka diizinkan memiliki Kanaan bukan hanya untuk ditempati, melainkan menempatinya dan menjadikan diri serta bangsa mereka sebagai role model dalam iman kepada Allah. Hal ini berarti ada unsur kerugma atau unsur pemberitaan atau memberi kesaksian kepada bangsa lain yang belum mengenal Allah.

\section{Konsep Misi dalam Perjanjian Baru (Kerajaan Allah)}

Konsep Misi Perjanjian Baru, tidak bisa dilepaskan dari topik tentang kerajaan Allah. Yohanes Pembaptis memberitakan "kerajaan Allah sudah dekat" (Mrk. 1:15), begitu juga para murid (Luk.10:9,11). Dalam pelayanan-Nya Yesus selalu memberitakan tentang "Kerajaan Allah ada di tengah-tengah kamu" (Luk. 17:21). Kerajaan yang dimaksud di sini tentunya bukanlah masalah geografis atau daerah maupun politis, tetapi menyangkut realitas dan orang-orang. Kerajaan Allah tidak hanya terbatas

21 Cook, Christian Mission, hal. 31-58.

22 Ibid, hal.19. 


\section{MISIOLOGI}

pada bangsa Israel, tetapi seluruh bumi. Model pelaksanaan misi dalam Perjanjian Baru yang tergambar dalam pelayanan Yesus terpusat pada pemberitaan tentang kerajaan Allah yang dalamnya seluruh umat manusia dipersiapkan masuk dalamnya. Adapun filosofi pelayanan misi yang dijalankan oleh Yesus (di mana selanjutnya ini merupakan gambaran pelaksanaan misi selanjutnya oleh para Rasul dan gereja) didasarkan pada kasih dan kuasa. Penulis Injil Yohanes dan Matius menjelaskan tentang hal ini: "Karena begitu besar kasih Allah akan dunia ini, sehingga Ia telah mengaruniakan Anak-Nya yang tunggal, supaya setiap orang yang percaya kepada-Nya tidak binasa, melainkan beroleh hidup yang kekal. Sebab Allah mengutus Anak-Nya ke dalam dunia bukan untuk menghakimi dunia, melainkan untuk menyelamatkannya oleh Dia. Barangsiapa percaya kepada-Nya, ia tidak akan dihukum; barangsiapa tidak percaya, ia telah berada di bawah hukuman, sebab ia tidak percaya dalam nama Anak Tunggal Allah" (Yoh. 3:16-18). "Demikianlah Yesus berkeliling ke semua kota dan desa; Ia mengajar dalam rumah-rumah ibadat dan memberitakan Injil Kerajaan Surga serta melenyapkan segala penyakit dan kelemahan. Melihat orang banyak itu, tergeraklah hati Yesus oleh belas kasihan kepada mereka, karena mereka lelah dan terlantar seperti domba yang tidak bergembala" (Mat. 9:35-36). Ketika Yesus memberitakan kerajaan Allah, hal itu selalu dihubungkan dengan kasih terhadap orangorang yang sedang terlantar oleh karena dosa dan dihubungkan dengan kuasa untuk melenyapkan segala sakit penyakit dan kelemahan. Dari sini terlihat dengan jelas bahwa pelayanan misi adalah pelayanan yang menjawab kebutuhan, baik secara rohani maupun jasmani.

David J. Bosch menjelaskan bahwa model misi Perjanjian Baru yang diperkenalkan oleh Yesus merupakan model 
misi dalam paradigma yang baru dan bersifat inklusif sebab menyangkut mereka yang miskin dan kaya, yang diperintah dan yang memerintah, yang sakit dan sehat, yang saleh dan berdosa, yang semua unsur dipersatukan dalam kebutuhan akan keselamatan dan menghancurkan tembok-tembok pemisah antargolongan dan lapisan masyarakat. ${ }^{23}$ Untuk menjawab kebutuhan manusia akan keselamatan dan penyatuan dalam kerajaan Allah, Yesus memproklamirkan diri-Nya sebagai pelayan dan bukan sebagai tuan. "Karena Anak Manusia juga datang bukan untuk dilayani, melainkan untuk melayani dan untuk memberikan nyawa-Nya menjadi tebusan bagi banyak orang." (Mrk. 10:45)

Oleh karena tuntutan keselamatan yang Allah sediakan dalam Kristus Yesus, setiap orang harus percaya dan menerima Kristus. Oleh karenaitu, tidak berhentisampai di situ, selanjutnya dibutuhkan pemberitaan tentang Kristus dan keselamatan yang tersedia di dalamnya agar setiap suku bangsa dan golongan masyarakat mendengarkan tentang dan menerima Kristus. Sehubungan dengan kepentingan ini, maka Yesus memberi tugas atau perintah kepada murid-murid atau gereja (setiap orang percaya) pada umumnya untuk pergi memberitakan Injil supaya semua bangsa menjadi murid bagi Kristus. "Lalu Ia berkata ke pada mereka: 'Pergilah ke seluruh dunia, beritakanlah Injil kepada segala makhluk. Siapa yang percaya dan dibaptis akan diselamatkan, tetapi siapa yang tidak percaya akan dihukum. Tanda-tanda ini akan menyertai orang-orang yang percaya: mereka akan mengusir setansetan demi nama-Ku, mereka akan berbicara dalam bahasa-bahasa yang baru bagi mereka, mereka akan memegang ular, dan sekalipun

23 David J. Bosch, Transformasi Misi Kristen (Jakarta: BPK Gunung Mulia, 2006), hal. 41. 


\section{MISIOLOGI}

mereka minum racun maut, mereka tidak akan mendapat celaka; mereka akan meletakkan tangannya atas orang sakit, dan orang itu akan sembuh"' (Mrk. 16:15-18). "Yesus mendekati mereka dan berkata: 'Kepada-Ku telah diberikan segala kuasa di Surga dan di bumi. Karena itu pergilah, jadikanlah semua bangsa murid-Ku dan baptislah mereka dalam nama Bapa dan Anak dan Roh Kudus, dan ajarlah mereka melakukan segala sesuatu yang telah Kuperintahkan kepadamu. Dan ketahuilah, Aku menyertai kamu senantiasa sampai kepada akhir zaman"' (Mat. 28:18-20). Perintah yang dicatat oleh Matius dan Markus ini kemudian dikenal sebagai Amanat Agung dan merupakan tugas pokok bagi gereja yang-tidak bisa tidakharus dilaksanakan.

Misiologi yang sebagaimana kita ketahui merupakan bagian dari bidang ilmu Teologi Praktika, dijelaskan oleh Kuiper denganmenggunakanistilah Misio Deiyangberarti "keseluruhan pekerjaan Allah menyelamatkan dunia lewat pemilihan dan pengutusan Israel, pengutusan para nabi kepada Israel dan bangsa-bangsa, pengutusan Kristus, dan pengutusan rasul-rasul serta semua orang percaya oleh Kristus kepada bangsa-bangsa. ${ }^{24}$ Dari pengertian ini, jelas terlihat bahwa misi adalah isi hati Allah yang dilaksanakan lewat para utusan-Nya yang ada dalam dunia, dan gereja adalah merupakan umat pilihan Allah dalam menerima dan melaksanakan misi Allah, yaitu pemberitaan Injil keselamatan yang tersedia dalam Kristus Yesus.

Amanat Agung merupakan landasan berpijak bagi gereja untuk melaksanakan misi Allah bagi dunia. Oleh karena hakikat gereja (ekklesia) adalah pelaksana dari misi Allah maka gereja sebagai organisasi dan organisme bertanggungjawab penuh

24 de Kuiper, Misiologia, hal. 10. 
pada pelaksanaan tugas yang diberikan. Bahkan sehubungan dengan tugas gereja sebagai pelaksana misi Allah, Yesus menggambarkannya sebagai pemegang kunci Kerajaan Surga, "Kepadamu akan Kuberikan kunci Kerajaan Surga. Apa yang kauikat di dunia ini akan terikat di Surga dan apa yang kaulepaskan di dunia ini akan terlepas di Surga" (Mat. 16:19). Menurut penulis, perkataan ini menggambarkan kepercayaan Allah secara penuh kepada gereja dan juga sekaligus menggambarkan besarnya tanggungjawab gereja. Kepercayaan ini juga menggambarkan benang merah dari karya misi Allah dalam Perjanjian Lama ke Perjanjian Baru sebab janji yang sama pernah Allah ungkapkan kepada Abraham dan keturunannya: "Aku akan memberkati orangorang yang memberkati engkau, dan mengutuk orang-orang yang mengutuk engkau, dan olehmu semua kaum di muka bumi akan mendapat berkat" (Kej. 12:3). Artinya, Gereja bertanggungjawab penuh dalam melaksanakan misi Allah, sebagai pemegang kunci Kerajaan Surga, yaitu tempat yang Allah inginkan semua orang masuk dalamnya. Oleh karena itu, gereja mempunyai tanggungjawab besar dalam melaksanakan tugas panggilannya.

Berdasarkan Amanat Agung yang diterima oleh para murid, dengan model dan contoh yang telah diperkenalkan oleh Yesus sebelumnya kepada mereka, para murid melaksanakan tugas tanggungjawab ini yang titik tolaknya dimulai pada hari Pentakosta, hari yang dikenal sebagai masa pencurahan Roh Kudus. Sejak peritiwa Pentakosta, Gereja terus melaksanakan fungsinya untuk membuka dan mempersilakan sebanyak mungkin orang masuk dalam Kerajaan Surga lewat pemberitaan Injil dengan Kasih dan Kuasa serta tanda-tanda mukjizat yang terus menyertai dan meneguhkan pemberitaan para Rasul. Adapun desain pemberitaan Injil dalam gereja mula-mula 


\section{MISIOLOGI}

seperti yang diungkapkan oleh Yesus sebelum Dia terangkat ke surga, yaitu dimulai dari Yerusalem, Yudea, Samaria, dan sampai ke ujung bumi (Kis. 1:8). Gereja mula-mula dalam melaksanakan tugasnya yang dimotori oleh para Rasul Kristus, mengalami berbagai tantangan baik dari aspek pemberitaan Injil maupun ancaman aniaya secara fisik. Namun dengan dasar Amanat Agung yang olehnya Tuhan Yesus berjanji akan menyertai sampai pada kesudahannya, mereka terus berjuang tanpa ada ketakutan dalam memberitakan Injil kepada seluruh suku, kaum, bangsa, dan bahasa.

Dalam Perjanjian Baru, para murid diutus untuk memberitakan dan mendemonstrasikan kuasa pemerintahan Allah yang membebaskan dan menyembuhkan (Mat. 10:5-8). Sebagai rasul, mereka diutus untuk memuridkan, membaptis, dan mengajar (Mat. 28:18-20). Yesus mengutus mereka ke dunia dalam cara yang sama seperti Bapa telah mengutus-Nya, dan hal ini memunculkan berbagai pertanyaan dan tantangan yang menarik (Yoh. 17:18; 20:21). Paulus dan Barnabas diutus untuk membawa bantuan bencana kelaparan (Kis. 11:27-30). Kemudian, mereka diutus untuk melakukan penginjilan dan perintisan jemaat (Kis. 13:1-3). ${ }^{25}$

\section{Kisah Para Rasul}

Kisah Para Rasul menceritakan bahwa para rasul pergi untuk memenuhi misi ini. Dalam Kisah Para Rasul 8:12, dikatakan bahwa Filipus pergi ke Samaria memberitakan Injil. Misinya itu digambarkan dalam kata-kata berikut: “... memberitakan

25 Christopher J. H. Wright, Misi Umat Allah:Sebuah Teologi Biblika Tentang Misi Gereja (Jakarta: Literatur Perkantas, 2011), hal. 26-27. 
Injil tentang Kerajaan Allah." Perjanjian Baru bahasa Yunani mempunyai akar kata yang sama untuk kata benda "Injil" dan kata kerja "menginjil" atau "memberitakan Injil." Kitab Matius 24:14 berbicara tentang "Injil Kerajaan" dan Kisah Para Rasul 8:12 tentang "memberitakan Injil tentang Kerajaan Allah." Injil Kerajaan ini harus diberitakan di seluruh dunia. Filipus pergi ke Samaria, menginjili tentang Kerajaan Allah, yakni memberitakan Injil Kerajaan. Terdapat ungkapan yang sama dalam Kisah Para Rasul 8:12 dan Matius 24:14, kecuali bahwa ada kata kerja dan bukan kata benda dengan kata depan "tentang" diselipkan dalam frase tersebut dalam Kisah Para Rasul. ${ }^{26}$

Rasul Paulus yang dikenal sebagai Rasulbagibangsa-bangsa lain setelah pertobatannya yang hebat, selalu mengatakan bahwa berita Injil harus disampaikan kepada seluruh umat manusia bagi keselamatan mereka. Di Roma 1:16 dikatakan: "Sebab aku mempunyai keyakinan yang kokoh dalam Injil, karena Injil adalah kekuatan Allah yang menyelamatkan setiap orang yang percaya, pertama-tama orang Yahudi, tetapi juga orang Yunani." Paulus mengungkapkan keyakinannya bahwa lewat penerimaan terhadap Kristus, setiap orang menerima pengampunan dosa dan hidup kekal, hal itu diperuntukkan bukan saja kepada satu bangsa, tetapi kepada seluruh suku bangsa yang ada dalam dunia. Bagaimana supaya setiap suku bangsa menjadi percaya dan menerima keselamatan dalam Kristus? Gereja harus keluar atau pergi memberitakan Injil sebab hal itu adalah tugas pokok baginya. Dalam suratnya kepada jemaat Korintus, Paulus mempertegas cara gereja harus bertanggungjawab melaksanakan tugasnya. Kitab 1 Korintus 9:16 berkata: "Karena

26 George Eldon Ladd, "Injil Kerajaan," dalam Misi Menurut Perspektif Alkitab (Jakarta: Yayasan Komunikasi Bina Kasih, 2007), hal. 91. 


\section{MISIOLOGI}

jika aku memberitakan Injil, aku tidak mempunyai alasan untuk memegahkan diri. Sebab itu adalah keharusan bagiku. Celakalah aku, jika aku tidak memberitakan Injil." Berarti, orang percaya (gereja) bagi Kristus hanya terjadi bila mereka melaksanakan tugas pokoknya, yaitu memberitakan Injil supaya misi Allah sampai kepada seluruh kaum dan bahasa.

Rasul Paulus bisa dikatakan sebagai seorang misionaris yang paling berhasil sepanjang zaman. Dari setiap perjalanan misi yang ia lakukan, berita Injil diperdengarkan di dunia Roma dan jemaat-jemaat yang berkembang didirikan. Dari misi yang dilakukan Paulus itu lahir pekabar-pekabar Injil yang baru. Tentu saja keberhasilan dalam pelayanan Rasul Paulus didukung banyak faktor. Selain dari komitmennya dalam pemberitaan Injil, tentu saja Roh Kudus sangat berperan dan turut bekerja dalam kehidupan dan dalam setiap pemberitaannya. Roh Kudus pula yang membuat seseorang menerima dan berubah oleh berita Injil itu. Hal ini diakuinya dalam banyak kesempatan lewat surat-suratnya.

\section{Karakter Misi Perjanjian Baru ${ }^{27}$}

Misi dalam Perjanjian baru bersifat sentrifugal, yaitu dari pusat ke luar. Bersifat sentrifugal berarti bahwa dari gereja kabar keselamatan disampaikan kepada semua suku-suku bangsa. Misi dalam Perjanjian Baru bersifat sentrifugal tertulis dalam Matius 28:18-20 dan lebih dikenal dengan Amanat Agung.

Jika di Perjanjian Lama Allah menyatakan rencanaNya untuk menyelamatkan dunia melalui kedatangan sang Juruselamat maka dalam Perjanjian Baru Allah menggenapi

27 Sakphin Poskoporus, Dosen Paska sarjana STT Real Batam. 
nubuat tersebut. Jika di Perjanjian Lama misi bersifat sentripetal (dariluarke dalam/pusat/Yerusalem), dalam pengertian bangsabangsa datang kepada Israel dan mereka dapat mengenal serta menyembah Tuhan yang benar maka misi dalam Perjanjian Baru bersifat sentrifugal (dari pusat/Yerusalem ke luar), yang berarti bahwa dari gereja kabar keselamatan akan disampaikan kepada semua suku-suku bangsa. Meskipun demikian, misi dalam Perjanjian Baru (PB) merupakan kelanjutan misi Allah dalam Perjanjian Lama.

Artinya, Perjanjian Baru juga bersifat misi. Harold Cook menyatakan "Dalam PB, misi adalah ekspresi yang wajar dari kekristenan yang hidup." Ia menegaskan, sifat hakiki kekristenan adalah misi. ${ }^{28}$ Misi merupakan kehendak Allah yang harus ditaati karena kehendak Allah selalu memiliki implikasi praktis. ${ }^{29}$ Berkaitan dengan misi, Perjanjian Baru berada di atas segala buku-buku misi. Perjanjian Baru ditulis oleh para misionaris bagi gereja-gereja yang misioner dan delapan belas berita misi mengungkapkan agama yang misioner bagi seluruh dunia. "Dalam situasi yang nyata dan penting," demikian Carver menyatakan, "Perjanjian Baru adalah produk usaha penginjilan/ misi." Fakta yang penting untuk diingat adalah Roh Kudus memberikan kepada kita wahyu kristiani untuk memenuhi kebutuhan akhir pekerjaan misi dalam bersaksi tentang Yesus (di seluruh dunia dalam seluruh kata-kata). Oleh karenanya Perjanjian Baru tidak hanya dokumen yang berisi misi Injil, tetapi hanya misi Injil. "Hal ini secara mendalam menghindarkannya menjadi sesuatu yang lain" kata Horton. "Ia bukanlah hukum perburuhan atau kode yang menarik, bukan sistem stereotype

28 Brougham, Merencanakan Misi Lewat Gereja-gereja Asia, hal. 18.

29 Rainer Schuman, Misi Holistik Masa Kini (Jayapura: STT GKI I.S. Kijne, 2004), hal. 166. 


\section{MISIOLOGI}

dari institusi gereja, bukan kegiatan seremonial atau pendeta, atau gedung gereja-yang semuanya adalah akumulasi atau hasil pertumbuhan-tetapi secara simpel dan teguh adalah suara, suara tangisan di padang gurun, suara dari surga, suara yang mengundang semua manusia kepada Kerajaan Allah dan berkata, "Biarlah dia yang mendengar datang."

Dengan jelas kita dapat melihat kitab Injil memuat pengajaran-pengajaran-Nya mengenai pengampunan kekal bagi manusia yang percaya kepada-Nya. Menyelamatkan dunia dari hukuman kekal dan menjadikan seluruh bangsa muridNya merupakan tugas yang Dia emban. Dia tidak hanya bermisi dengan pengajaran-Nya, tetapi juga dengan pengurbanan-Nya. Saat ini, tugas menjadikan seluruhbangsa murid-Nya merupakan Amanat Agung yang harus dilanjutkan oleh pengikut-pengikutNya sesuai dengan perintah-Nya. Berikut kita pelajari beberapa pengajaran penting tentang misi dalam PB.

\section{Injil Matius menggambarkan Kristus adalah satu-satunya penguasa Dunia}

Injil Matius ditulis dengan tujuan untuk mengungkapkan Kristus sebagai penguasa dunia; otoritas-Nya atas segalanya, karakter-Nya yang kuat, karya penebusan-Nya dan pengajaranNya. Matius mengawali Injil yang ditulisnya dengan silsilah yang menempatkan Yesus dalam garis keturunan Daud. "Inilah silsilah Yesus Kristus, anak Daud, anak Abraham" (Mat. 1:1). Hal ini mengaitkan Yesus dengan dua perjanjian antara Allah dan manusia yaitu perjanjian dengan Daud ("untuk menegakkan kerajaannya"-2 Sam. 7:8-16) dan perjanjian dengan Abraham ("olehmu semua bangsa akan memperoleh berkat"-Kej. 15:18). 
Matius menutup Injilnya dengan perintah untuk menjadikan semua bangsa murid Kristus (Mat. 28:18-20).

\section{Injil Markus mengungkapkan Yesus sebagai pelayan Allah yang berkuasa}

Injil ini menggabungkan pakaian kerajaan dengan kain pelayan. Penggabungan antara kemuliaan Yesus sebagai raja melalui otoritasnya dan kerendahhatiannya dengan bekerja keras untuk mewujudkan isi hati Bapa-Nya bahkan sampai mengurbankan diri-Nya bagi penyelamatan manusia. "Karena Anak Manusia juga datang bukan untuk dilayani, melainkan untuk melayani dan untuk memberikan nyawa-Nya menjadi tebusan bagi banyak orang" (Mrk. 10:45). Sebagai Injil yang menyingkapkan Yesus sebagai pelayan, karakteristik Injil tulisan Markus ini lebih terfokus pada perbuatan daripada kata-kata.

Kristus Yesus adalah pekerja ilahi yang merestorasi dunia yang hilangdanjatuh. Dia mengusirsetan-setan, menyembuhkan berbagai penyakit, memperbarui mereka yang berdosa, mengalahkan kematian dan menghidupkan. Dia memulihkan yang hancur. Dia juga menghardik dan mengusir setan untuk menolong mereka yang dapat dipulihkan dan ditolong. Dia adalah pelayan Allah, berkuasa penuh, menderita, berkarya tanpa henti, sampai pada akhirnya. Dia berkarya tanpa cacat sehingga manusia dapat diselamatkan. Dia mengimpartasikan roh yang sama kepada para murid-Nya, sampai setelah kematianNya "Merekapun pergilah memberitakan Injil ke segala penjuru, dan Tuhan turut bekerja dan meneguhkan firman itu dengan tanda-tanda yang menyertainya" (Mrk. 16:20). Injil Markus adalah panggilan untuk menderita bersama Kristus bagi penebusan dunia. 


\section{Lukas dan Kisah Para Rasul: karya Lukas ini mengungkaplan Yesus sebagai anak manusia yang sempurna yang memiliki solidaritas kepada kaum miskin dan terbuang}

Lukas memulai Injilnya dengan menyatakan kejadian-kejadian ajaib berkaitan dengan kelahiran Yohanes dan Yesus. Ia mengisahkan kunjungan malaikat Gabriel kepada Maria dan pernyataan kepada Maria tentang fakta yang mulia bahwa ia akan menjadi ibu dari Mesias: "Karenanya, juga pribadi yang suci akan dilahirkan darimu dan harus disebut sebagai Anak Allah" (Luk. 1:25-38). Seluruh Injil Lukas adalah Wahyu (pengungkapan) bahwa manusia berdosa dapat diselamatkan dan menjadi sempurna, suci, diberkati, dan kekal. Kalimat kuncinya adalah "Sebab Anak Manusia datang untukmencari dan menyelamatkanyang hilang" (Luk. 19:10). Injil Lukas mengungkapkan adanya janji pemulihan yang hanya ada dalam Yesus. Penyelamatan yang Yesus lakukan bagi umat manusia adalah bukti kepedulian-Nya kepada manusia dan dunia yang terhilang. Kristus menjawab kegagalan dunia dengan kemenangan yang mereka alami (Luk. 24:46-49).

\section{Injil Yohanes menyingkapkan Yesus sebagaiAnak Allah}

Injil Yohanes ditulis untuk menyatakan ke-Tuhanan Yesus. Dalamnya kita mendapati keteraturan progresivitas katakata dan karya-karya yang memperlihatkan Yesus adalah Anak Allah. Tujuan pokok Injil Yohanes adalah agar manusia percaya bahwa Yesus adalah Kristus, Anak Allah (Yoh. 20:31). Injil Yohanes memperlihatkan bahwa Kristus dalam realitasnya adalah Anak Allah dan merupakan identitas dan realitas dari kehadiran-Nya, simpati-Nya, kuasa-Nya bersama gereja-Nya sepanjang waktu. Yohanes menggambarkan Yesus sebagai 
Firman, Anak Allah (Yoh. 1:12-13). Dalam eksistensi-Nya, kita memperoleh pengetahuan akan artinya eksistensi Allah. Dalam perkataan-Nya, kita belajar kebenaran mendasar dari Allah. Dalam tindakan-Nya, kita menemukan aktivitas Allah. Dalam Injil Yohanes, Kristus menghubungkan para murid-Nya kepada diri-Nya dengan cara menjadikan hidup dan aktivitas para murid menjadi kelanjutan pelayanan penebusan-Nya. "Sama seperti Bapa mengutus Aku, demikian juga sekarang Aku mengutus kamu" (Yoh. 20:21).

\section{Surat penggembalaan Paulus:Gereja sebagai Paguyuban Baru}

Misi dalamtulisan-tulisanPaulusada dalam konteks kemenangan Allah yang akan segera tiba. Surat-surat Paulus adalah suratsurat misionari dari hasil pekerjaan misinya. Surat-surat ini perlu dikaji secara keseluruhan untuk mendapatkan gambaran tentang misi.

a. Surat Roma: Surat ini ditulis sebab Paulus merasa bahwa gereja di Roma mempunyai posisi yang strategis. Semua gereja harus berdasar pada iman. Surat ini adalah manifesto "Kabar Baik"-nya. Tema surat yang diungkapkan adalah "Kebenaran asali Tuhan" (Rm. 1:16-17). Kebenaran ini dapat dicapai manusia melalui Kristus (Rm. 3:21-28) dan terbuka bagi orang Yahudi dan non-Yahudi (Rm. 3:29-30). Dunia digambarkan sedang menuju kehancuran (Rm. 3:923), di mana kondisi ini terjadi karena dosa Adam (Rm. 5:12). Namun, melalui kebenaran seseorang-Kristus, "anugerah cuma-cuma didapat melalui pembenaran dari 
Kristus" (Rm. 5:18). Surat Roma adalah Kabar Baik bagi dunia.

b. Surat 1 dan 2 Korintus: Surat ini ditulis untuk mereformasi penyalahgunaanyang mengancam untuk melemahkan kehidupan spiritual gereja di Korintus. Dalam surat ini, kita mendapatkan gambaran kesulitan nyata yang dihadapi oleh orang-orang Kristen di tengah komunitas yang membencinya. Kita melihat benturan antara kekristenan dan budaya. Belum lagi benturan dengan kepercayaan paganisme. Dalam surat ini, Paulus sebagai misionaris memberikan prinsip-prinsip kepercayaan terhadap Kristus dalam rangka membangun gereja Perjanjian Baru di daerah paganisme.

c. Surat Galatia: Surat ini ditulis untuk membetulkan ajaran-ajaran yang salah. Paulus mengumpulkan petobat-petobat baru non-Yahudi dan kemudian ada orang-orang yang menyesatkan mereka dengan mengatakan untuk menjadi seorang Kristen, mereka harus menjadi Yahudi. Tema dari surat Galatia adalah pembuktian Injil anugerah Tuhan tanpa syarat apa pun. Hal ini penting sebagai dokumen misi. Kunci pemikirannya adalah "membenarkan orang-orang bukan Yahudi oleh karena iman” (Gal. 3:8).

d. Surat Efesus: Surat ini ditulis untuk menempatkan gerejasebagaiinstitusiilahidanuntukmemperlihatkan cara anggota gereja seharusnya berlaku/berjalan. Dalam surat ini, kita mengetahui posisi yang mulia dari orang-orang yang percaya melalui anugerah. Kebenaran berkenaan dengan gereja yang adalah 
tubuh Kristus dan perjalanan yang berharga sebagai orang Kristen. Kita belajar bahwa dalam gereja, perbedaan antara Yahudi dan non-Yahudi tidak ada; semua sama di hadapan Kristus (Ef. 2:11-22).

e. Surat Filipi: Surat ini ditulis untuk mengekspresikan apresiasi yang mendalam dari rasul Paulus untuk uang yang dikirimkan gereja Filipi bagi dirinya (Flp. 4:15 - 19). Hanya gereja Filipi-lah yang diperlihatkan oleh catatan surat itu sebagai yang membantunya dan Paulus menerima bantuan keuangan mereka. Hal itu merupakan dukungan paling antusias yang diterima Paulus dan seharusnya menjadi model bagi semua gereja dalam misinya (Flp. 1:3-7).

f. Surat Kolose: Surat ini ditulis untuk menempatkan gereja sebagai penjaga dan untuk menyelamatkannya dari kesalahan guru-guru palsu yang mengaku sebagai orang Kristen, tetapi bermaksud untuk menyebarkan ide-ide Yahudi (Kol. 2:4-8). Kristus adalah satusatunya Penyelamat (Kol. 2:9-13). Paulus tidak hanya menulis bagi gereja saja, tetapi bagi gereja-gereja sepanjang sejarah untuk membimbimbing mereka dalam misinya di tengah ajaran sesat di dunia (Kol. 2:18-23; 4:15-16).

g. Surat 1 dan 2 Tesalonika: Surat ini ditulis untuk memberikan instruksi dalam doktrin-doktrin misi dan untuk menguatkan gereja mula-mula di tengah penganiayaan (1Tes.1:7-10). Surat kedua ditulis untuk memperbaiki impresi yang salah tentang kedatangan Kristus yang kedua dan untuk mendesak orang-orang 
Kristen Tesalonika untuk melanjutkan hidupnya (2 Tes. 2:1-5).

h. Surat 1 dan 2 Timotius dan Titus: Surat ini ditulis untuk menguatkan para rekan kerja Paulus. Paulus menasihati para pengkhotbah-pengkhotbah muda itu berkaitan dengan administrasi gereja. Ketika gereja bertumbuh dalam angka dan bertambah kuat, secara alami timbul pertanyaan akan aturan gereja, pengakuan iman, dan disiplin. Dalam lapangan misi, pertanyaan-pertanyaan itu pasti akan terjadi. Pertama-tama rasul Paulus menanganinya sendiri, tetapi pada perkembangan berikutnya tampak jelas diperlukan petunjuk-petunjuk yang jelas bagi gerejagereja sepanjang zaman. Inilah isi surat kepada Timotius dan Titus.

i. Surat Filemon: Surat ini adalah surat yang terpendek dari semua surat Paulus. Surat ini sangat bernuansa misi karena berisi tentang kebenaran, revolusi terhadap dunia kuno. Tidak hanya orang non-Yahudi dan orang luar, bahkan budak-pun dapat diterima di Kerajaan Allah dan harus diterima sebagai saudara dalam Kristus (Flp. 1:10, 14-16). Semua tulisan Paulus adalah karya misi dan tidak dapat dipahami terpisah dari usahanya untuk mengenalkan Kristus kepada bangsa-bangsa. Sebuah elemen yang konstan dan permanen pada pikiran dan pekerjaannya adalah misi. Kasih akan Kristus dan pikiran akan dunia yang terhilang membelenggunya. Dia sangat rindu semua diselamatkan. 


\section{Surat-surat Misi Lainnya.}

a. Surat Ibrani: Surat ini merupakan "connecting link" antara Perjanjian Lama dan Perjanjian Baru. Tujuan surat Ibrani adalah untuk menunjukkan bahwa institusi besar hukum Taurat adalah bersifat simbolis dan kebenaran yang belum jelas akhirnya telah diungkapkan (Ibr. 9:1-11). Kuil dan para imam, altar dan pengurbanan, tabir dan Kemah Suci memasuki arti "World-Wide." Hal ini dipenuhi dan digenapi dalam Kristus (Ibr. 9:11-15). Hal ini sebenarnya tidak pernah hilang melainkan tersimpan oleh bangsa Yahudi sampai akhirnya diberikan kepada seluruh dunia. Hal yang terjadi di Israel sebelumnya adalah persiapan yang panjang. Sekarang, hal ini sudah diungkapkan bagi dunia dan bayangan yang menutupi telah tersingkap dan isinya telah nyata.

b. Surat Yakobus: Surat Yakobus mempunyai isi dan cara pandang yang misioner. Surat ini adalah pengajaran singkat dari Yesus dan sangat bersifat praktis tentang iman, perbuatan baik, dan doa. Pokok-pokok isinya tidak dengan jelas menunjukkan tentang misi, tetapi paling tidak berupa kesaksian akan perluasan misi pada zaman apostolik. Hal ini karena surat Yakobus ditujukan bagi "Dua belas suku yang tersebar di luar negeri” (Yak. 1:1), yaitu orang-orang Yahudi yang telah menjadi Kristen dan tersebar di seluruh dunia. Yakobus sendiri, seperti yang dinyatakan dalam Kisah Para Rasul dan tradisi adalah seorang Yahudi ortodoks. Oleh karena itu, surat ini sangat mengesankan melihat 
ia bersaksi melalui suratnya yang mengabarkan pesan kekristenan.

c. Surat Petrus: Surat Petus memberikan bukti yang kuat akan rekonsiliasi yang tercapai pada zaman apostolik antara mereka yang berpikiran sempit dan mereka yang mempunyai konsep pemikiran yang luas, yang didukung oleh Paulus. Pada satu kesempatan, Paulus menentang Petrus secara langsung (Gal. 2:11), tetapi surat ini menyatakan bahwa Petrus telah sepenuhnya menerima pemikiran misioner Paulus. Hal ini mengindikasikan bahwa tujuan surat ini adalah memberikan kesaksian bagi kemajuan misi yang dilakukan oleh gereja-gereja apostolik.

d. Surat Yohanes: Surat Yohanes mempunyai signifikansi yang kaya dalam misi. Bagian ini kelihatannya bersifat maju dalam pemikiran karena tidak membahas keadaan dan detail sejarah. Yohanes melihat kebenaran kekristenan tidak mempunyai relasi dengan Yudaisme melainkan dalam relasinya kepada dunia. Maksudnya kekristenan bukan bagi bangsa Yahudi saja melainkan bagi dunia. Dia menulis bahwa manusia dapat percaya pada kebenaran yang memang dimaksudkan bagi manusia tanpa ada pembatasan. Dia melihat seluruh dunia berada dalam kuasa kegelapan dan kehadiran Kristus berasal dari Allah dan terangNya di dunia dimaksudkan agar dunia mendapatkan terang (1 Yoh. 1:5-7). 


\section{Wahyu Terakhir}

Kitab Wahyu menutup Perjanjian Baru dengan menyengat sebab mengulangi dan mengonfirmasi pesan misioner Injil. Pribadi yang muncul dalam ke-empat Injil seperti munculnya terang dalam kegelapan, muncul dalam kitab Wahyu dengan digambarkan sebagai merpati yang mempesona dari badai petang hari (Why. 1:12-18). Dalam kitab ini, Anak Manusia menyatakan diri-Nya sebagai "Alpha dan Omega, Yang Pertama dan Yang Terakhir." Dia memberikan pesan kepada gereja-Nya sebagai Domba yang dibunuh, tetapi sekarang hidup selamanya dan dimahkotai dalam kemenangan. Kita mendengar semua suara dari seluruh dunia menyatakan Dia sebagai "Raja di atas segala Raja dan Tuhan di atas segala Tuhan" (Why. 19:1-16).

\section{E. Hubungan Mandat Misi dengan Pemuridan}

Tidak ada seorang pun yang dapat menafikan hubungan misi dengan pemuridan. Atau menekankan misi dan menolak pemuridan atau sebaliknya. Misi dan pemuridan merupakan dua unsur penting yang harus ada dalam pergerakan gereja. Namun, kedua unsur ini seolah "mati suri" di tengah perkembangan zaman.

Gereja diperhadapkan dengan berbagai kompleksitas tantangan, terutama tantangan sosial, ekonomi dan politik. Persoalan sosial ekonomi membuat gereja hanya berputar pada misi sosial, yakni memerhatikan orang yang lapar, terpinggirkan, tergusur, dan bencana alam. Bagaimana dengan pemuridan? Pemuridan pun bernasib sama.

Menurut Greg Ogden, dalam menghadapi millenium baru, harus diakui bahwa pertumbuhan gereja saat ini sangatlah 


\section{MISIOLOGI}

dangkal. Semangat gereja untuk makin meluas tidak disertai dengan komitmen untuk bertumbuh makin mendalam. Bagaimana mungkin para pemimpin Kristen meratapi degradasi moral yang terjadi dalam masyarakat, padahal ada begitu banyak pribadi yang mengaku memiliki relasi mendalam dengan Yesus Kristus? Jika mereka adalah pengikut Yesus yang sejati, kita tidak akan menutup muka dengan rasa malu pada zaman yang telah berbalik dari Tuhan ini. Masalah kita sesungguhnya terletak pada umat Tuhan yang tidak disiplin, tidak dimuridkan, tidak taat, dan yang mengabaikan Firman Tuhan. ${ }^{30}$

Persoalan-persoalan sosial yang dihadapi gereja seakanakan menggiring gereja kepada hanya mencari jalan keluar atas persoalan-persoalan humanitas semata. Gereja harus menyadari bahwa kita harus taat kepada hal yang dikatakan Yesus. Yesus sudah mengatakan kepada gereja untuk melakukan mandat misi dengan pergi dan menjadikan semua bangsa murid, dan ini harus ditaati. Payne mengatakan bahwa "The commission for missionaries to make disciples of all nations begins with calling others to repentance and faith in Jesus. But, it does not end there. This commission also involves teaching these new Kingdom citizens to obey all of Jesus' commands" (Mat 28:20). ${ }^{31}$ Artinya, gereja tidak cukup hanya mengetahui bahwa dalam Alkitab Yesus pernah mengatakan bahwa gereja harus pergi dan menjadikan semua bangsa muridNya, melainkan bagaimana mengajar orang untuk menerapkan hal yang telah Yesus perintahkan.

Pada poin terakhir ini, saya memang hanya mengemukakan hubungan misi dengan pemuridan. Namun, ketika kita memahami

30 Greg Ogden, Pemuridan yang Mengubahkan (Surabaya: PERKANTAS, 2014).

31 J.D. Payne, Discipleship in Church Planting: Some Guidelines to Move Us Forward (Wheaton, IL: Good News Publisher, 2011), hal. 7. 
pentingnya pemuridan maka kita tidak hanya berhenti pada pemuridan itu sendiri melainkan dapat melahirkan pemimpinpemimpin dalam gereja. Jim Putman mengatakan bahwa gereja membutuhkan pemimpin-pemimpin karena itu gereja harus menerapkan pemuridan untuk melahirkan pemimpin. ${ }^{32}$

Alasan Putman berkaitan dengan pemuridan dan pemimpin sangat sederhana yakni, setiap orang percaya yang telah dimuridkan dan dewasa secara rohani maka ia layak untuk dipercayakan tanggungjawab-tanggungjawab rohani. "I want the process of finding and developing good leaders to be simple and reproducible so that our church can become purposeful and effective at making disciples and leaders.... and effective reproducing culture is created when leaders believe in something strongly enough to live out those principles...." ${ }^{33}$ Bahkan Putman memberikan contoh bahwa dalam pelayanannya di Real Life Ministry, para pemimpin-pemimpin (pastors and missionaries) dapat mengelola gereja karena memiliki kemampuan dan kepribadian yang kuat dalam Kristus.

Oleh karena itu, "discipleship is one who committed to Jesus mission to save people from their sin-God mission is our mission (hand); One who being changed by Christ (heart)-Mat. 7:17-20; One who following chirst (head). ${ }^{34}$ Pemuridan adalah seseorang yang membagikan kehidupannya bagi orang lain yang baru percaya demi menolong mereka untuk mengenal dan memperkenalkan Kristus. Kristus membagikan hidupnya kepada murid-muridNya selama 3,5 tahun. Yesus tidak takut jika gereja tidak maju,

32 Jim Putman, Building Churches that Make Disciples(Colorado: NavPress, 2010), hal. 165-168.

33 Ibid.

34 Ibid, hal. 32. 


\section{MISIOLOGI}

bahkan mati. Yesus hanya mengerjakan pemuridan karena pemuridan bersifat reproducible.

Perintah Yesus dalam Matius 28:19-20 berbunyi: "Karena itu pergilah, jadikanlah semua bangsa murid-Ku dan baptislah mereka dalam nama Bapa dan Anak dan Roh Kudus, dan ajarlah mereka melakukan segala sesuatu yang telah Kuperintahkan kepadamu." Sesuai struktur tata bahasa aslinya (Yunani), kalimat induk dalam Amanat Agung adalah "Jadikanlah semua bangsa muridKu." Kata: "pergilah... baptislah ... ajarlah" merupakan kata kerja yang bergantung pada kata kerja utama "jadikanlah ... murid-Ku".

Perhatikanlah, berdasarkan Matius 28:19-20, kita mendapati satu amanat,

Jadikanlah semua bangsa -- -kuantitas

Murid-Ku--kualitas, dengan tiga tahap:

Baptislah--Penginjilan

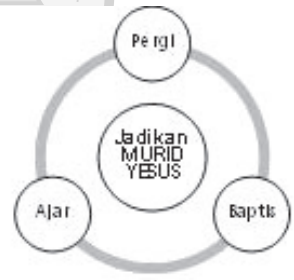

Ajarlah--Pembinaan

Pergilah--Pengutusan

Jika kita memerhatikan dengan saksama perintah ini maka kata pergi berada di awal dan berada di akhir, yakni pergilah, baptislah, dan ajarlah, setelah itu harus pergi.

Oleh sebab itu, pemuridan memberikan dampak positif. Menurut Herdy Hutabarat, ada lima dampak positif gereja menerapkan prinsip pemuridan:

1. Menyiapkan dan membangun suatu generasi yang kuat

2. Menghasilkan pemimpin-pemimpin rohani yang dewasa dan berkarakter seperti Kristus 
3. Mengantisipasi krisis kepemimpinan

4. Menciptakan proses multiplikasi atau pelipatgandaan

5. Kita sendiri akan mengalami pertumbuhan baik dalam kesetiaan, kesabaran, ketekunan, keuletan, hati Bapa, dan hikmat untuk menasihati.

Jika sebaliknya tidak menerapkan pemuridan maka para pemimpin diperhadapkan dengan krisis-krisis kepemimpinan dan krisis pemimpin dalam gereja.

Jadi, sejak di Perjanjian Lama saat Allah memilih Israel dalam kovenan-Nya sebagai umat pilihan-Nya, Allah juga telah menetapkan rencana-Nya di mana Israel tidak hanya menjadi bangsa yang menerima Kanaan sebagai negeri yang dijanjikan dengan berdiam diri melainkan menerima Kanaan dengan tanggungjawab memperkenalkan YHWH kepada bangsa-bangsa yang belum mengenalnya. Tugas ini merupakan inti berita dalam penetapan Israel sebagai umat pilihan.

Keberlanjutan tugas memperkenalkan Allah kepada bangsa-bangsa yang tidak mengenal Allah tidak semata-mata pada Israel (ini pun karena kedegilan hati mereka). Penetapan dan pengutusan Israel ke Kanaan hanya merupakan langkah awal Allah dalam rencana-Nya. Sejak kehadiran Kristus di bumi, babak baru tentang tugas tersebut pun terkuak. Pelayanan Yesus selama 3,5 tahun merupakan keberlanjutan dari rencana Allah dan cara program Allah dapat berjalan dengan baik maka Yesus membangun sistem yang berkelanjutan yakni pemuridan yang bersifat reproducible.

Dengan menunjuk pada Matius 28:18-20, Yesus memberikan perintah tentang keberlanjutan tugas dan 


\section{MISIOLOGI}

tanggungjawab memperkenalkan Allah kepada bangsa-bangsa lain yang belum mengenal Allah. Tugas tersebut dalam catatan Matius berkesinambungan dalam satu tema dengan Kisah para Rasul 1:8.

Yesus memperkenalkan prinsip pemuridan dan keberlanjutan misi sebagai langkah-langkah dalam membangun dan menciptakan sumber daya manusia untuk tugas dimaksud. Pemuridan kemudian menjadi "jiwa" dari pelayanan Yesus. Sebab selama 3,5 tahun, Yesus memberikan teladan tentang cara membangun gereja yang kuat dan berkelanjutan, yakni "pergilah, baptislah dan ajarlah."

Pemuridan kemudian dilihat oleh beberapa orang pada masakini sebagaijalan menciptakan pemimpin-pemimpin dalam misi dan pelayanan pastoral. Pemuridan pun kemudian dilihat sebagai jalan keluar atas "tekanan" yang dialami pemimpinpemimpin gereja, jalan keluar atas krisis-krisis kepemimpinan dan krisis pemimpin. Namun mengapa banyak gereja yang meskipun menyadari pemuridan merupakan perintah Yesus, tetapi tidak menerapkannya? Membiarkan pemuridan "mati suri" atau dalam ungkapan Leroy Eims, Pemuridan, Seni yang Hilang? 


\section{Mission In Action Bermisi Menanam Gereja Itu Mudah (Asal Tahu Caranya)}

\section{Misi Allah (Misio Dei)}

\section{Definisi Misi}

Misiologi adalah studi tentang Tuhan (Teologi), pengalaman dengan Tuhan (experience God), berjalan dengan kebenaran-Nya (Yoh. 3:16), di mana anthropologi (studi tentang manusia dan budaya) dan sejarah dalam masa tertentu terlibat dalamnya. ${ }^{1}$

Istilah misi dalam Kamus Besar Bahasa Indonesia memiliki arti "kegiatan menyebarkan Kabar Gembira (Injil) dan mendirikan jemaat-jemaat setempat, yang dilakukan atas dasar pengutusan sebagai kelanjutan misi Kristus." ${ }^{2}$ Sedangkan istilah "misioner" merupakan kata kerja yang berarti "bersifat misi".

1 Definisi yang dibuat penulis bersama rekan-rekan "Misiologist" ketika masa kuliah Master of Art in Intracultural Education di BIU.

2 Kamus Besar Bahasa Indonesia, edisi kedua (Jakarta: Balai Pustaka, 1991), hal. 660. 


\section{MISIOLOGI}

Atau dengan kata lain misi menjadi tujuan dan fokus yang terus dilakukan/dikerjakan.

Kata misi (mission) berasal dari bahasa Latin "mission" yang diangkat dari kata dasar "mittere", yang berkaitan dengan kata "missum", yang memiliki arti "to send" (mengirim/mengutus), "act of sending, being sent or delegated by authority/persons sent, etc." Sedangkan dalam bahasa Yunani ialah "apostello/ apostello." Kata "apostello" tidak berarti mengirim/kirim secara umum. Istilah ini lebih berarti mengirim dengan otoritas. Dalam hal ini, orang yang dikirim atau diutus diperlengkapi dengan otoritas dari yang mengirim untuk tujuan khusus yang akan dicapai. ${ }^{3}$ Tekanan penting dari "misi atau pengutusan Allah" berbicara tentang Allah sebagai pengutus, yaitu Allah adalah sumber,inisiator, dinamisator, pelaksana, dan penggenap misi-Nya.

Sebagai sumber misi, landasan bagi rencana Allah yang kekal ini beranjak dari hati-Nya, dan Allah sendiri yang berinisiatif untuk melaksanakan misi-Nya. Hal ini ditunjang oleh dinamika-Nya (kekuatan/kuasa) guna melaksanakan dan mencapai misi-Nya tersebut. ${ }^{4}$

Dengan demikian, misi Allah adalah Allah mengutus dengan otoritas dan kuasa kepada para murid-Nya untuk melaksanakan Amanat Agung, yaitu menjadikan semua bangsa (etne: suku bangsa) murid-Nya.

3 David J. Bosch, Transformasi Misi Kristen (Jakarta: BPK Gunung Mulia, 1997), hal. 1.

4 Yakob Tomatala, Penginjilan Masa Kini, jil. 1 (Jakarta: YT Leadership Foundation,1997), hal. 2-5. 


\section{2. "Denyut Jantung" Allah di dalam Misi}

Allah adalah Allah yang memiliki misi. Dia sendiri adalah seorang misionaris dari Surga. I Timotius 2:4 berkata: "yang menghendaki semua orang diselamatkan dan memperoleh pengetahuan tentang kebenaran." Hal terakhir yang Yesus lakukan sebelum Dia naik ke surga adalah memberikan murid-Nya Amanat Agung: "Karena itu pergilah, jadikanlah semua bangsa murid-Ku dan baptislah mereka dalam nama Bapa dan Anak dan Roh Kudus" (Mat. 28:19).

Dalam Markus 16:15, Yesus berbicara tentang penginjilan dunia, "Engkau, pergilah ke seluruh dunia, beritakanlah Injil kepada segala makhluk." Mengenai penginjilan dunia, Lukas 24:47 mengatakan, "...dan lagi: dalam nama-Nya berita tentang pertobatan dan pengampunan dosa harus disampaikan kepada segala bangsa, mulai dari Yerusalem."

Sedangkan dalam Yohanes 20:21, Yesus berbicara tentang penginjilan dunia ketika Dia berkata, "Seperti Bapa mengutus Aku, juga sekarang Aku mengutus kamu." Sebelum Dia naik ke surga, Kisah Para Rasul 1:8 mencatat Dia berkata, "Kamu akan menerima kuasa, kalau Roh Kudus turun ke atas kamu, dan kamu akan menjadi saksi-Ku di Yerusalem dan di seluruh Yudea dan Samaria, dan sampai ke ujung bumi."

Misi yang memancar dari hati Tuhan melalui penginjilan dan pemuridan adalah untuk memimpin orang lain kepada Allah, menjadi murid yang bersaksi. Hal ini mencakup misi pencarian (membawa dunia yang terhilang), misi penyelamatan (Melalui Yesus Kristus) dan misi pemeliharaan-memberi makan (menjadikan tubuh Kristus yang bertanggung jawab).

Hari-hari ini gereja hanya melakukan misi yang dianggap bagian dari program gereja, tidak beda dengan pelayanan 


\section{MISIOLOGI}

gerejawi lainnya. Padahal, misi Amanat agung adalah inti dan dasar dari gereja. Gereja ada karena pelayanan misi maka dari itu gereja harus bermisi.

Pada umumnya, gereja-gereja, baik kecil maupun besar yang sering disebut "mega church" lebih mengonsentrasikan sumber-sumber gereja (resources) kepada bangunan dan alat (sarana dan prasarana) untuk memuaskan (menghibur) jemaatnya dalam pujian dan penyembahan (Praise and Worship) daripada menyenangkan hati Tuhan dengan bermisi dan menjangkau jiwa.

Amanat Agung hanya digunakan untuk mengumpulkan dana dan kebanyakan dana digunakan untuk sesuatu yang prioritas menurut kebijakan gereja lokal dan melupakan panggilannya yang hakiki.

Dengan katalain, gereja menyuarakan nama Yesus hanya di empat sisi gedung. Minggu demi minggu, pembicara berkotbah, mengajar keselamatan kepada orang-orang yang telah selamat. Lebih jauh lagi, orang-orang percaya menghabiskan waktunya dengan sesama orang Kristen dan menghindari orang-orang yang disebut "orang dunia" yang dianggap sebagai orang yang tidak layak. Kita menolak dengan alasan yang bagus untuk bersentuhan dengan dunia, tetapi Yesus mengatakan: "bukan orang sehat memerlukan tabib, tetapi orang sakit. Jadi pergilah dan pelajarilah arti firman ini: yang Kukehendaki ialah belas kasihan dan bukan persembahan, karena Aku datang bukan untuk memanggil orang benar, melainkan orang berdosa" (Mat. 9:12-13).

Hal yang dikatakan di atas benar dan benar juga bahwa fakta penyebaran misionaris dalam tugas misi tidaklah sebanding. Perhatikan tabel dan diagram di bawah ini: 


\begin{tabular}{|c|c|c|c|c|c|c|c|}
\hline \multicolumn{8}{|c|}{ Missionaries sent and received, 2010} \\
\hline \multicolumn{2}{|c|}{ Most sent } & \multicolumn{2}{|c|}{$\begin{array}{l}\text { Most sent per million } \\
\text { church members }\end{array}$} & \multicolumn{2}{|c|}{ Most received } & \multicolumn{2}{|c|}{$\begin{array}{l}\text { Most received per } \\
\text { million population }\end{array}$} \\
\hline Country & Total & Country* & Total & Country & Total & Country* & Total \\
\hline 1 United States & 127,000 & Palestine & 3,401 & United States & 32,400 & Micronesia & 4,779 \\
\hline 2 Brazil & 34,000 & Ireland & 2,131 & Brazil & 20,000 & Samoa & 4,167 \\
\hline 3 France & 21,000 & Malta & 1,994 & Russia & 20,000 & Tonga & 3,922 \\
\hline 4 Spain & 21,000 & Samoa & 1,802 & DR Congo & 15,000 & Netherlands Ant. & 3,317 \\
\hline 5 Italy & 20,000 & South Korea & 1,014 & South Africa & 12,000 & Guam & 2,833 \\
\hline 6 South Korea & 20,000 & Belgium & 872 & France & 10,000 & French Polynesia & 1,612 \\
\hline 7 United Kingdom & 15,000 & Singapore & 815 & United Kingdom & 10,000 & USVVirgin Islands & 1,532 \\
\hline 8 Germany & 14,000 & Tonga & 619 & Argentina & 10,000 & Belize & 1,438 \\
\hline 9 India & 10,000 & United States & 614 & Chile & 8,500 & Vanuatu & 1,399 \\
\hline 10 Canada & 8,500 & Netherlands & 602 & India & 8,000 & New Caledonia & 1,344 \\
\hline \multicolumn{2}{|c|}{$\begin{array}{l}{ }^{*} \text { Countries greater than } 100.000 \\
\text { population }\end{array}$} & & Center for $\mathrm{t}$ & udy of Global Christianit & & & \\
\hline
\end{tabular}

Tabel 1. Negara-negara pengirim Misionari dan penerima ${ }^{5}$

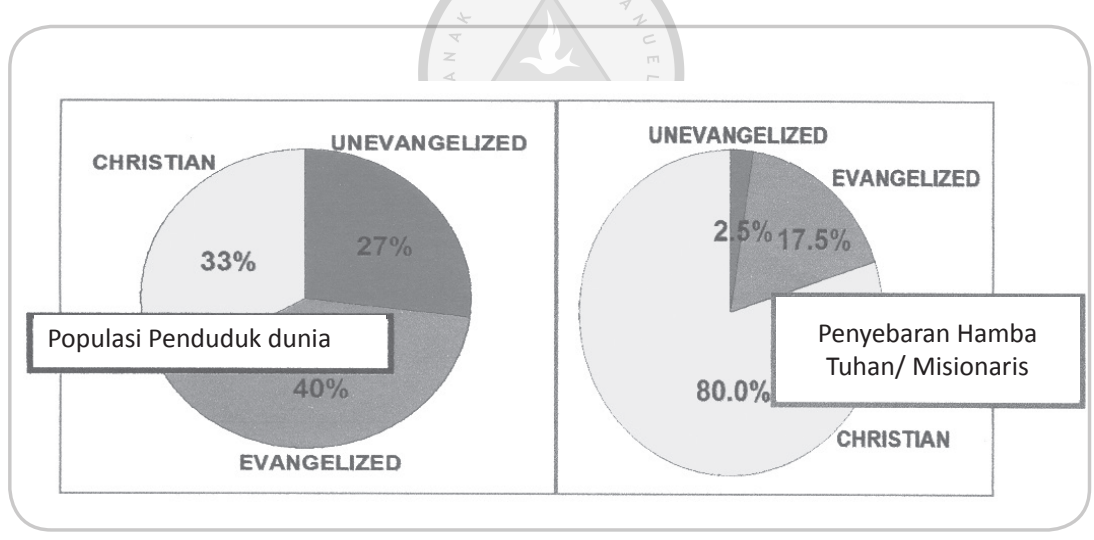

Diagram 01: Populasi penduduk Dunia dan penyebaran misionari ${ }^{6}$

5 Christianity in Its Global Context, 1970-2020. Centre for the Study of Global Christianity, Gordon Cornwell Theological Seminary.

6 Diagram dibuat berdasarkan data dari CGC 2013. 


\begin{tabular}{|c|c|c|c|c|c|c|c|}
\hline \multicolumn{8}{|c|}{ Chrestianity by continent and region, 1970-2020 } \\
\hline \multirow[b]{2}{*}{ Country } & \multicolumn{3}{|c|}{1970} & \multicolumn{3}{|c|}{2020} & \multirow[b]{2}{*}{ Rate* } \\
\hline & Population & Christians & $\%$ & Population & Christians & $\%$ & \\
\hline Africa & $368,148,000$ & 142.609 .000 & 38.7 & $1,278,199,000$ & $630.644,000$ & 493 & 302 \\
\hline Eastern Atrica & $111,412,000$ & $55,009,000$ & 494 & $431,818,000$ & $289,235,000$ & 67.0 & 3.38 \\
\hline Middle Africa & $40,750,000$ & $30,113,000$ & 73.9 & $161,689,000$ & $134,618,000$ & 83.3 & 3.04 \\
\hline Northern Aftica & $83,158,000$ & $6.723,000$ & 81 & $231,126,000$ & $10,815,000$ & 47 & 0.96 \\
\hline Southem Africa & $25,454,000$ & $19,286,000$ & 75.8 & $61,187,000$ & $50,361,000$ & 82.3 & 1.94 \\
\hline Western Atnca & $107.374,000$ & $31,478,000$ & 293 & $392,379.000$ & $145.614,000$ & $37 \%$ & 311 \\
\hline Asia & $2,134,902,000$ & $95,398,000$ & 45 & $4,565,522,000$ & $420,390,000$ & 9.2 & 3.01 \\
\hline Eastern Asta & $984,073,000$ & $11,449.000$ & 12 & $1,622.681,000$ & $170.953,000$ & 105 & 5.56 \\
\hline South-central Asia & $778,833,000$ & $27,222,000$ & 3.5 & $2,009,512,000$ & $81,374,000$ & 4.1 & 2.21 \\
\hline South-eastern Asta & $285.161,000$ & $50,371,000$ & 177 & $655.941,000$ & $153.217,000$ & 23.4 & 2.25 \\
\hline Western Asia & $86,925,000$ & $6,358,000$ & 73 & $277,388,000$ & $14,847,000$ & 5.4 & 1.71 \\
\hline Europe & $655,881,000$ & $491,756,000$ & 750 & $744,179,000$ & $580,305,000$ & 780 & 0.33 \\
\hline Eastern Europe & $276,229,000$ & $158.050,000$ & 572 & $289,166,000$ & $248,098,000$ & 85.8 & 0.91 \\
\hline Northern Europe & $87,351,000$ & $75.752,000$ & 867 & $104,525,000$ & $76.221,000$ & 72.9 & 0.01 \\
\hline Southern Europe & 126.766 .000 & $111,133,000$ & 877 & $158,477,000$ & 129.391 .000 & 81.7 & 030 \\
\hline Western Europe & $165.535,000$ & 146.822 .000 & 887 & 192.010 .000 & 126.595 .000 & 659 & -0.30 \\
\hline Latin America & $286,378,000$ & $269.856,000$ & 942 & $652,181,000$ & $600,553,000$ & 92,1 & 1.61 \\
\hline Caribbean & $25.327,000$ & $19.816,000$ & 782 & $44,321,000$ & $37,529,000$ & $B 47$ & 1.29 \\
\hline Central America & $69,590,000$ & 67.945 .000 & 976 & $176,389,000$ & $168,540,000$ & 95.6 & 1.83 \\
\hline South America & $191,462,000$ & $182,096,000$ & 951 & $431,471,000$ & $394,484,000$ & 91.4 & 156 \\
\hline Northern America & $231,285,000$ & $210,952,000$ & 912 & $374,394,000$ & $288,005,000$ & 76.9 & 0.62 \\
\hline Oceania & $19,506,000$ & $18.037,000$ & 925 & $42,057,000$ & $30.818,000$ & 73.3 & 1.08 \\
\hline Australia/New Zeoland & $15,548,000$ & $14,520,000$ & 034 & $30,065,000$ & $19.735,000$ & 65.6 & 0.62 \\
\hline Melanesia & $3,306,000$ & 2.885 .000 & 873 & $10.661,000$ & $9.822,000$ & 92.1 & 248 \\
\hline Micronetia & 242,000 & 231.000 & 95.5 & 603.000 & 561,000 & 931 & 1.79 \\
\hline Polynesia & 409,000 & 401,000 & 981 & 728,000 & 699,000 & 96.1 & 1. 12 \\
\hline Globe & $3,696,189,000$ & $1,228,608,000$ & 33.2 & $7,656,531,000$ & $2,550,714,000$ & 33.3 & 1.47 \\
\hline 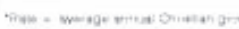 & 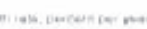 & $a, y=0$ & & 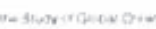 & 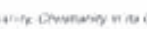 & fortcen & $x=x_{i}$ \\
\hline
\end{tabular}

Tabel 2.Pemeluk Agama Kristen Dunia ${ }^{7}$

Menurut data dalam table 1, mayoritas gereja-gereja di dunia melayani di daerah yang mayoritas orangnya sudah percaya.

Keristenan di Indonesia dimulai seawal-awalnya pada abad ke-12 oleh orang Kristen Mesir yang memulai pelayanan di Barus, di pantai Barat Sumatera Utara. ${ }^{8}$ Namun tampaknya, misi di bumi nusantara secara resmi diakui dalam catatan sejarah kekristenan adalah kegiatan keagamaan yang dimulai dengan

7 Christianity in Its Global Context, 1970-2020. Centre for the Study of Global Christianity, Gordon Cornwell Theological Seminary.

8 Jan Sihar Aritonang and Karel Steenbrink, ed., A History of Christianity in Indonesia (Leiden and Boston, MA: Brill, 2008), hal. 3. 
datangnya pedagang Portugis pada abad ke-16. ${ }^{9}$ Jika benar bahwa sudah pernah ada aktivitas dan orang percaya di Barus seperti yang tercatat dalam History of Chritianity in Indonesia, ${ }^{10}$ maka kekristenan masuk ke Indonesia seawal-awalnya pada abad ke12. Namun walaupun demikian, sampai hari ini Indonesia tetap memerlukan misi. Melihat data yang ada, orang yang mengaku dirinya "percaya" di Indonesia hanya sebanyak 16\%, sedangkan populasi orang Muslim adalah $80.31 \% .{ }^{11}$ Menurut Indonesia People Network, ${ }^{12}$ Indonesia memiliki suku sebanyak 781, yang 130 suku adalah suku terabaikan ${ }^{13}$ dengan jumlah 142.000.000 jiwa, hal itu berarti lebih dari $65 \%$ total penduduk Indonesia belum terjangkau.

Merespons realitas di lapangan dan untuk menerima tantangan yang ada serta menaati sang Maestro dengan mendengar-Nya, misi adalah keharusan bagi lembaga yang disebut gereja.

\section{Pengalaman dan Kesaksian Pelayanan sebagai Dasar Bermisi}

Pengalaman saya dalam penanaman gereja dimulai 24 tahun yang lalu (1992). Dimulai dengan keterlibatan secara "accident"/kecelakaan yang disengaja. Ketika itu saya bekerja sebagai peneliti hutan di

\footnotetext{
9 Ibid.

10 Ibid.

11 Operation World 2010, hal 339.

12 Indonesian People Network 2017, un-Official data.

13 Suku terabaikan adalah suku yang jumlah populasinya lebih dari 10.000 jiwa, tetapi orang Kristennya kurang dari 1\%. Definisi ini dibuat oleh IPN (Indonesian People Network) dan tentu berbeda dengan definisi suku terabaikan dari Joshua Project, International Mission Board Baptist dan juga World Christian data base.
} 


\section{MISIOLOGI}

sebuah perusahaan Hutan Tanaman Industri di hutan daerah Jambi, sambil bekerja merintis persekutuan untuk melayani pekerja-pekerja yang beragama Kristen yang hidup terpencil di tempat kerja.

Pada 1997, tepatnya pada 9 September, saya menyerahkan hidup sepenuh waktu dalam pertemuan para pengerja gereja di pulau Batam. Di sana, selama 3 hari dua malam, saya menangis sebelum mengambil keputusan untuk menyerahkan hidup untuk menjadi hamba Tuhan.

Beberapa gereja lokal di luar kota Jambi mulai dirintis. Pada akhir 1999, saya pindah ke pulau Batam dan memulai keterlibatan dalam pelayanan di pulau-pulau yang ada di Kepulauan Riau yang masih merupakan bagian dari Provinsi Riau. Pada akhir 2001, saya bergabung ke Gereja Indonesia yang ada di Singapura (BCS) dan diangkat sebagai penanggung jawab misi. Saya memulai pelayanan misi bangsa-bangsa ketika ditugasi untuk melanjutkan perintisan yang pernah saya coba-coba mulai di Melaka. Ketika itu, saya pernah melayani satu orang Chinese Malaysia dari suku Kong Hu (Cantonese). Ia adalah seorang pemuda yang tinggi besar yang hendak bunuh diri karena "overdosis narkoba". Ia mencoba menggantung diri dengan tali pinggang yang digantungkan ke kipas angin yang ada di langit-langit kamar. Namun, karena badannya besar dan tali pinggangnya terlalu kecil, putuslah tali pinggang itu dan jatuhlah ia. Ia lalu mengganti tali pinggang yang lebih besar dan kembali menggantungkannya ke kipas angin yang sama. Namun kali ini, kipas angin yang jatuh dari langitlangit. Pemuda yang tinggi besar ini akhirnya dibawa ke penulis. Masih kuat di ingatan penulis, ketika itu saya menanyakan "Do you speak English?" Ia menjawab sambil menggelengkan kepala: "No... no...no..." "Do you speak Malay?" "No...no...no...". Dan ia berbicara dengan saya menggunakan bahasa Cantonese sehingga saya yang ganti mengatakan "no...no...no...". Saya menumpangkan tangan dengan menggunakan bahasa Roh dan mulai berkata-kata bahwa 
Yesus mengasihi dirinya (Jesus Loves you) berulang ulang dan Roh Kudus mulai berkarya, menjamah dirinya dan pemuda ini menangis meronta-ronta seperti terjadi kelepasan, airmata, keringat, dan air liur bercampur menjadi satu. saya tahu Tuhan Yesus sedang menjamah dirinya. Keluarga besarnya bersukacita. Orang ini merupakan orang damai (man of peace) yang dipercaya sebagai pintu masuk penjangkauan. Singkat cerita, keluarga besar orang yang dilayani ini meminjamkan mobil kepada saya dan bersama rekan pelayanan mulai berkeliling mencari di tempat ada orang Indonesia yang bekerja. Dari sana saya mulai bertanya adakah orang Manado atau Batak atau Timor di kilang di daerah Cheng Melaka (karena orang-orang dari daerah ini biasanya orang Kristen), bukankah Paulus melakukan hal yang sama? Ketika ia ada di kota Filipi, ia mencari orang-orang Yahudi untuk diajar (Kis. 16:13)? Akhirnya, saya bertemu dengan beberapa orang Indonesia yang bekerja di kilang dan pembantu rumah tangga. saya memperkenalkan diri sebagai hamba Tuhan dari Indonesia. Masih kuat dalam ingatan penulis, ketika mengajak mereka berdoa, kelihatan sekali kekakuan dan ketakutan sertaintimidasiyang ada. Hal itu karena situasi waktu itu tidak memungkinkan orang untuk bersekutu. Singkat cerita, tiap minggu saya menyempatkan berkunjung dan mengadakan pertemuan, sampai akhirnya diputuskan harus punya ibadah khusus orang yang berbahasa Indonesia atau Melayu. Pada 4 Februari 2001, ibadah perdana BCM Melaka dimulai pukul 2 siang di sebuah hotel di daerah downtown Melaka. Dari hotel, ibadah akhirnya berpindah ke gereja lokal yang bernama "upperroom" fellowship dan akhirnya menjadi gereja yang mandiri dengan nama BCM (Bethany Church Malaysia) Melaka ter-register di bawah NECF (National Evangelical Church Fellowship) Malaysia.

Dari Melaka, kota berikutnya yang dijangkau adalah Segamat di wilayah Johor. Selanjutnya, dalam tahun yang sama sekitar Juni 2001, 


\section{MISIOLOGI}

pelayanan mulai merambah Pulau Penang yang di sana saya dibantu oleh 8 orang mahasiswa BBC (Bethany Bible College) ${ }^{14}$ Jakarta yang sedang melakukan praktik selama 10 hari. Beberapa orang diturunkan di Ipoh, Penang, dan Kuala Lumpur. Di Penang, tim bersaksi kepada seorang Kedar dari Jawa (Mbak Wiwik, saat ini sudah berkeluarga dan tinggal di Penang) yang kebetulan berada di satu bus ketika hendak berangkat ke tempat kerja. Ternyata ia langsung merespons dan siap untuk dibaptis. Tim yang di Ipoh melakukan survei dan doa keliling. Begitu juga di Kuala lumpur.

Dalam tahun yang sama, perintisan gereja di Kuala Lumpur dimulai. Sangat sulit waktu itu untuk mengetahui, tempat posisi orang Indonesia tersebar. Saya dan tim yang ada mengadakan doa puasa dan doa keliling selama 3 hari, dan akhirnya bisa bertemu dengan seorang pelajar Indonesia. Sukacita besar terjadi saat itu, tetapi belum terjadi apa-apa. Pengalaman yang tidak terlupakan ketika saya datang untuk yang ke-duakali-nya di Kuala Lumpur, pada pukul 4 subuh. Tiba di stasiun Bus Pudu Raya, tidak tahu arah yang harus dituju, saya hanya duduk di depan sebuah kedai 7-11, sambil bertanya-tanya kepada Tuhan arah yang harus saya tuju, ke kiriatau kekanan? Akhirnya, saya diingatkan tentang seorang teman yang pernah bertemu sebelumnya, seorang Hamba Tuhan di daerah Cheras. Saya akhirnya tinggal di rumah itu untuk beberapa hari.

Pada akhirnya saya memutuskan, untuk Kuala Lumpur akan segera dimulai dengan KKR, karena saya dipinjam kan tempat ibadah di sebuah gereja lokal di pusat kota dekat Kuala Lumpur daerah Ampang. Tim kecil yang datang dari Melaka membantu mendistribusikan selebaran dua minggu sebelum hari H. Pada hari kebaktian semua tim sudah siap, terdiri dari pemain musik, WL dan saya sendiri sebagai

14 BBC sudah tutup sekarang. 
pengkhotbah. Semua tim menjadi usher. Namun, setelah pukul 5 sore pada 8 Juli 2001, hanya ada 1 jemaat yang hadir. Terpaksa ibadah diundur sambil berdoa memohon agar Tuhan tambahkan 1 jiwa, sebagai awal dari persetujuan Tuhan untuk kami memulai ibadah di Kuala Lumpur. Waktu selesai doa, saya bangkit dari berlutut, ternyata jemaat yang hadir sudah bertambah 1 orang lagi. Ibadah perdana dimulai dengan bergairah walaupun hanya dua jemaat. Namun hari ini untuk sekitar Kuala Lumpur dan Selangor, jemaat yang hadir mencapai 1200++. Tidak hanya di Semenanjung, pelayanan juga merambah ke Sarawak dan Sabah. Sampai hari ini, gereja BCM telah mencapai kurang lebih 45 cabang di seluruh Malaysia. ${ }^{15}$

Pada Februari 2002, saya terlibat dalam kepanitiaan Eastern Gateway Prayer Convocation, dari Jerusalem House of Prayer for all Nations, sebagai International Liasion dari Bethany Church Singapore yang membawa saya pada 22 Februari 2002, menginjakkan kaki di Thailand, Laos, Kamboja, Vietnam, dan Myanmar untuk mempromosikan Konvokasi Doa dan mengundang para pemimpin gereja untuk menghadirinya. Perjalanan satu minggu ini, membuat mata rohani saya terbuka untuk mulai memikirkan penjangkauan suku-suku yang ada di bangsa-bangsa. Dalam tahun yang sama pada 22 Oktober 2012, saya kembali terbang ke Asia Selatan, dengan tim Singapore City Mission untuk melatih hamba-hamba Tuhan bawah tanah di Bhutan. Untuk sampai ke kota perbatasan Phuntsholing, team menggunakan jalur udara dari Kalkuta, India ke kota terdekat Bedogra dan dilanjutkan dengan jalan darat menuju kota perbatasan. Setelah 4 hari melakukan pelatihan, saya melanjutkan perjalanan ke Katmandhu, Nepal, bertemu dengan pimpinan gereja Nepal untuk mempromosikan Konvokasi Doa 2003. Dari Nepal menelusurijalan darat menuju perbatasan Tibet. Beberapa hari di Nepal, melayani orang-

15 BCM (Bethany Church Malaysia) adalah anggota dari NECF sejak 2001. 


\section{MISIOLOGI}

orang Tibet dalam pengungsian dan juga melayani para biku yang ada di monastry vihara. Dari Nepal saya terbang ke Dacca,Bangladesh, dan dari Bangladesh saya terbang ke Colombo, Srilanka, dan dari Srilanka terbang ke Male ibukota Maladewa (Maldives) dan terus pulang ke Singapura, menyeberang ke Batam di rumah tempat tinggal penulis.

Pada 2003, saya memulai perintisan di Manila, Filipina, sedangkan pengutusan missionari wanita pertama pada bulan Mei 2005 dan BCP Phillipens berdiri 16 Agustus 2005, dengan jemaat mulamula tiga puluh orang.

Pada awal Oktober 2003 saya berkesempatan untuk mengikuti Haggai Institute di Maui. Hal ini sangat membantu saya menemukan tujuan pelayanan dan mengubah paradigma penjangkauan serta penginjilan. Dari Maui, saya mempunyai kerinduan untuk melayani lebih banyak waktu untuk bangsa sendiri, tetapi bagaimana? Berdoa lebih banyak untuk Indonesia dan Sumatera secara khusus karena saya baru mengerti bahwa Sumatera adalah pulau yang tidak terinjili pada abad modern. ${ }^{16}$

Pada 2004, tahun euforia dunia politik Indonesia, saya secara langsung terlibat dalamnya, yaitu sebagai ketua tim sukses satu partai Kristen. Hal itu membawa saya keliling Kepulauan Riau untuk berbagi visi. Sementara saya masih tetap menjabat sebagai Mission Director dari Bethany Church Singapore.

Pada Juli 2004, saya memulai perintisan di Kamboja, diawali dengan mission trip ke kota Poi Pet di perbatasan Thailand dan Kamboja. Dari sini saya menantang tim misi yang mulai direkrut

16 Pioneer and Mission Organization focus on Muslim UPG's: It is the largest unevangelized island on earth. Most of its peoples are staunchly Muslim. If it were a nation, only 9 other nations would have more unreached peoples. Sumatra is the home of 52 known unreached people groups consisting of 25 million people. Of the 52, 48 have no indigenous church and 34 of them have no known gospel workers. 
dari teman-teman pelayanan. Pada Mei 2005, saya sendiri mengantar utusan misi yang dititipkan ke rekan pelayanan, yaitu teman misionari yang telah menetap dan membangun pusat pelatihan sekolah Alkitab Antioch Institute ${ }^{17}$ untuk belajar bahasa Khmer. Perjalanan ini menarik sekali karena harus terbang dari Singapura ke Ho Chi Minh Vietnam, melalui jalan darat ke Pnom Penh Cambodia. Singgah di Ho Chi Minh Vietnam (Selatan), dari sini juga timbul hati untuk melayani dan membuka pelayanan di Vietnam.

Pada 4 September 2004, saya diundang untuk menghadiri pertemuan doa Pacific Selatan di Papettee French Polynesia, yang dalam pertemuan ini diadakan juga pertemuan di istana Presidennya karena presiden yang terpilih adalah seorang percaya lahir baru. Pertemuan itu dihadiri kelompok dari suku Melanisia (PNG, Vanuatu, Fiji, New Caledonia), Polynisia (Hawaian, New Zealand, American Samoa, Sampoa), Micronisia (Palau, Nauru, Kiribati, etc)

Pada 1 Oktober 2004, kerinduan saya untuk melayani orang Indonesia, di bangsa sendiri dijawab oleh Tuhan Yesus. Saya diminta untuk menggembalakan sebuah gereja lokal dari Gereja Bethel Indonesia di Tanjung Pinang, Pulau Bintan, Kepulauan Riau. Dari Tanjung Pinang saya mulai menyusun rencana kerja jangka pendek per dua tahun untuk menargetkan kota-kota yang akan dijangkau dalam pelayanan. Tujuh Kabupaten Kota dan 52 Kecamatan masuk dalam rencana. Pada akhir 2004, ketika saya mengalami "Frustasi" dalam pengembalaan yang baru berjalan dua bulan, Tuhan memberi visi dari Matius 9:34-35.

PadaJanuari 2005, didirikan Mercy Mission Relief, yang akhirnya jadi LSM.* Mercy Mission bergerak cepat untuk memerhatikan orang-

17 Antioch Institute Cambodia akhirnya bekerja sama dengan STT Real Batam. Nota kesepahaman atau MOU ditandatangani pada Juni 2015 di PnomPenh. 


\section{MISIOLOGI}

orang yang menderita dan memerlukan pertolongan. Tugas pertama adalah membantu Tsunami Aceh, dimana kota ini kami adopsi dalam doa.

Dalam tahun yang sama pelayanan di Batam dimulai dengan cell group. Setelah National Prayer Conference 2005 (5 Mei 2005) yang berbarengan dengan Transform World 2005 di Jakarta, di mana saya terlibat dalam mission focus group, Indonesia memutuskan akan mengirim 5000 misionari ke bangsa-bangsa. Berkaitan dengan itu, saya memutuskan untuk terlibat dan memulai pusat pelatihan di Batam dengan nama POAB (Pusat Apostolik Bangsa-bangsa), di mana di tempat ini akan dilatih para calon tenaga misi baik untuk misi reguler maupun bangsa-bangsa serta untuk suku terabaikan (unreached). Angkatan perdana dimulai pada Februari 2006 dengan 18 siswa/ $i^{1}$, yang mana mereka saat ini telah mengembalakan di berbagai tempat baik di dalam maupun di luar negeri. DNA misi telah lahir. Selama pelatihan 3,5 bulan dan praktek 6 bulan di lapangan, murid POAB memberi kontribusi signifikan untuk pertumbuhan gereja di Batam.

Dalam tahun itu juga, melalui gereja BICK Korea, ${ }^{18}$ penulis diundang untuk melayani NPC (National Prayer Conference), tepatnya padal 5 Juni 2005 di Indo-Korea, gereja Korea yang memiliki bahasa Indonesia Service dan gereja-gereja Indonesia di Korea serta gerejagereja Korea yang memiliki misi di Indonesia. Saya sempat merasakan penolakan karena panitia ingin membatalkan saya sebagai pembicara karena tidak mengenal bahkan namanya tidak pernah mereka dengar. Puji Tuhan, akhirnya acara Tuhan lawat dengan luar biasa.

Pada 17 Oktober 2005 GBI Windsor diresmikan oleh BPD (Badan Pekerja Daerah) GBI Kepulauan Riau. Dalam bulan itu juga, untuk mendukung pelayanan yang ada di Batam, Yayasan Pintu Gerbang

18 BIC Korea di Seoul dirintis oleh Ps. Moniq Martin pada September 2003. 
Kasih didirikan. Yayasan ini bergerak dalam OTA (Orang Tua Asuh), Klinik dan pelayanan Media.

Dengan adanya $P O A B^{19}$ pada awal Februari 2006, sasaran dan target misi diperjelas, rata-rata setiap tahun minimal pertambahan sembilan gereja baru dalam misi regular; 2-3 gereja di Kepulauan Riau, 1-2 gereja di luar Kepulauan Riau dalam wilayah Indonesia, 2-3 gereja baru di Malaysia, 1 gereja baru di satu negara baru di Asia maupun Asia Tenggara. Pertumbuhan ini sangat tidak memuaskan jika dibandingkan dengan kegerakan akhir zaman sehingga Tuhan memberi konsep-konsep baru dalam CPM (Church Planting Movement/Kegerakan penanaman Gereja), yang olehnya satu gereja lokal bisa menanam begitu banyak gereja. Adapun pengertian gereja dan kegerakan penanaman gereja akan dijelaskan dalam bab-bab berikutnya.

Pada 2006 merupakan tahun yang tidak terlupakan, dalam perjalanan kembali ke Korea untuk mengunjungi utusan misi yang menggembalakan, secara tiba-tiba saya diundang untuk mengisi ibadah Minggu English Service di Yoido FullGospel Church yang merupakan gereja terbesar di dunia waktu itu. Hal ini merupakan promosi yang tidak pernah terlupakan. ${ }^{2}$

Dalam tahun ini juga, pelayanan radio dimulai, dan perintisan sekolah-sekolah dan Bimbel dimulai. Klinik Pintu gerbang kasih diresmikan. ${ }^{3}$

Dalam Tahun ini juga saya dan istri untuk pertama kalinya ke Yerusalem, pusat dimana Misi pertama dimulai.

19 POAB (Pusat Orientasi Bangsa Bangsa) Batam adalah pusat pelatihan misi 3,5 bulan disertai praktik 6 bulan. Adapun materi pelatihan dibagi dalam $30 \%$ berbicara penginjilan dan pertumbuhan dan strategi, 30\% berbicara soal survival (bertahan hidup), 30\% berbicara soal keuangan (Increase income in Mission field), 10\% berbicara pastoral di lapangan. 


\section{MISIOLOGI}

Pada 2007, Pembangunan rumah Tuhan di Tanjungpinang dimulai. Selain itu dalam tahun ini, saya diundang pertama kali untuk menghadiri pertemuan anggota Parlemen Israel (Knesset) dan beberapa menteri dari partai Likud dan anggota Parlemen Jepang yang beragama Kristen. Pertemuan ini sangat berkesan karena saya mewakili Indonesia.

Pada 2008, pendirian rumah ibadah di Tanjung Pinang selesai. Dan dalam tahun ini saya dan istri menghadiri pertemuan Transform World Brazil di Sao Paolo.

Perintisan di Timor Leste juga dimulai pada tahun yang sama. Dalam suasana politikyang tidak menentu, perintisan dimulai. Sampai saat ini, IBTL-LGCC (Igreja Bethel Timor Leste, Last Generation City Church) sudah berdiri di berbagai daerah di Timor Leste.

Pada 2009, pertemuan ethne to ethne di Bogota Columbia, membuat saya memutuskan melanjutkan sekolah kejenjang Doktoral. Rekan sekerja dari Amerika yang juga teman sepelayanan di Cambodia dan seorang Profesor Misi dari Amerika yang lahir di Indonesia dan menjadi misionaris di Indonesia, merekomendasikan saya untuk melangkah kuliah bersama dengan praktisi misi dunia di kampus BIU (Bethany International University).

Pada 2010-2012, gereja-gereja misi terus bermunculan, perintisan-perintisan terus dilakukan baik dalam dan di luar negeri.

Penulis memulai kuliah perdana pada Januari 2011 dengan mengambil jurusan Master of Art in Intracultural Education di Singapura. Saya memutuskan untuk masuk asrama dan tinggal bersama dengan rekan-rekan dari berbagai negara baik Afrika maupun Asia. Puji Tuhan, saya lulus dengan predikat sangat baik dalam setahun dan melanjutkan ke jenjang Doktoral sampai hari ini.

Pada 2013, saya mulai terlibat di GCPN (Global Church Planting Network) dan ditunjuk sebagai fasilitator untuk Asia Tenggara. Pada 62 
tahun yang sama di pertemuan awal persiapan pertemuan regional, saya mengusulkan bahwa menara doa harus masuk dalam workshop. Hal ini karena saya banyak melihat dan mengikuti pertemuan di belahan bumi, semua pelaku misi dan church planter rata-rata dari lembaga misi menjadikan doa hanya merupakan acara rutin. Untuk itu, saya mengusulkan menara doa merupakan unsur esential yang harus dimasukkan dalam workshop-workshop pertemuan global maupun regional.

Pada tahun ini juga, sekolah Tinggi Teologi Real, meluluskan 19 mahasiswa angkatan pertama yang artinya itu merupakan lulusan pertama atau buah sulung.

Pada 2014, pertemuan SEACPN Batam (Jaringan penanaman gereja Asia Tenggara) menjadi momen pertama kalinyaworkshop menara doa dibicarakan. Saya sendiri ketika berbicara di pertemuan GCPN di Budapes Hongaria, paduan misi dan menara doa Indonesia menjadi model. Hal ini mendapat respons sangat positif.

Dalam tahun ini juga, kami memulai mission trip untuk menjejakkan kaki di Asia Selatan. India, Nepal, dan Tibet adalah sasaran kami.

Tahun 2015, Tim Real Care gabungan dari Mercy Mission relief dan STT Real, tim yang terdiri dari tim Medis, Konseling dan Mission Pastor terlibat dalam penanggulangan krisis pascagempa Nepal. Disini kami memutuskan untuk membuka perintisan di Katmandhu Nepal.

Pada tahun ini juga saya menginjakkan kaki di Johannesburg, South Africa untuk menghadiri pertemuan CPM-CPM Africa Church Planting dan persiapan Batam sebagai tempat pertemuan dunia.

Pada 2016, pelayanan Misi India dimulai. Kami mengutus puket II STT Real Batam, sebagai utusan misi ke daerah Dehdradun. Pada 2016 adalah tahun yang spesial, saat Batam menjadi tuan rumah 


\section{MISIOLOGI}

Pertemuan GCPN dan GACX (Global Alliance Church Multiplication), tepatnya pada 10-13 Mei. Pertemuan ini diikuti oleh orang-orang dari 45 negara dari lima benua, yang merupakan para pakar penanam gereja, baik dari lembaga misi maupun lembaga gereja. ${ }^{4}$

\section{Gereja yang Misioner}

Kitab Yohanes 20:21 berkata: "Maka kata Yesus sekali lagi: Damai sejahtera bagi kamu! Sama seperti Bapa mengutus Aku, demikian juga sekarang Aku mengutus kamu." Dari sini hal yang harus kita pahami adalah hal utus mengutus seharusnya menjadi kata kunci bagi setiap orang percaya maupun gereja Tuhan.

Arie de Kuiper ${ }^{20}$ dalam bukunya Misiologia membagi misi dalam empat kategori: Missio Ecclesiae (Pengutusan Gereja = pekerjaan missioner dari Jemaat Kristen sepanjang sejarah dunia), Missio Apostolorum (pengutusan para rasul), Missio Christi (Pengutusan Kristus dalam arti: a. Kristus mengutus murid-murid-Nya, b. Kristus diutus Allah, dan Missio Dei, yakni keseluruhan pekerjaan Allah untuk menyelamatkan dunia.

Saya sebagai praktisi misi dan juga gembala misi menyimpulkan bahwa misi dan penginjilan adalah kata yang tidak bisa dilupakan bagi gereja yang mengutus atau sering disebut gereja missioner. Penginjilan adalah sikap hidup individu setiap orang percaya. Memberitakan Injil dapat berarti bersaksi, membagi kabar baik, berbagi hidup tentang Kristus kepada setiap orang. ${ }^{21}$

20 Arie de Kuiper, Misiologia (Jakarta: BPK Gunung Mulia, 2015), hal. 10.

21 Lihat klasifikasi penginjilan Bab VI hal. 147 
Sementara misi adalah tanggung jawab setiap lembaga gereja yang mau tidak mau harus mengutus untuk membuka dan menjangkau daerah lain. Pengutusan yang dilakukan oleh lembaga gereja yang dipimpin oleh saya adalah:

\section{a. Misi Regular}

Misi regular adalah misi yang dilakukan dalam rangka penggenapan visi dan misi denominasional. Sebagai contoh, saya adalah gembala GBI (Gereja Bethel Indonesia). Sepanjang sejarah sinode ini, GBI menargetkan untuk menanam 10.000 gereja GBI di seluruh dunia. Merupakan kewajiban bagi gereja untuk mengembangkan GBI. Artinya, Gereja Bethel melahirkan Gereja Bethel. Adapun misi regular bisa dilakukan dengan berbagai cara:

a. Mengutus Hamba Tuhan/misionaris di tempat yang tidak ada orang percayanya dan memulai perintisan.

b. Memulai fellowship di tempat yang sudah ada jemaat GBI, tetapi tidak memiliki tempat ibadah.

c. Membagi jemaat yang ada dalam suatu wilayah tertentu yang berdekatan untuk memulai kelompok sel, fellowship atau ibadah yang berjauhan dengan gereja induk.

d. Memulai ibadah di tempat tertentu yang berjauhan secara geografi karena jemaat berpindah tugas atau domisili walaupun di tempat baru sesungguhnya sudah ada gereja lain. 


\section{MISIOLOGI}

\section{Misi bangsa bangsa}

Hal ini adalah panggilan gereja untuk mengutus dan membuka/ menanam gereja di luar "boundaries"/ di luar batas geografi dan politis dengan kata lain menanam gereja di negara lain.

Penjangkauan dapat dilakukan dengan merintis melalui "diaspora" (orang-orang Indonesia di luar negeri), baik pekerja maupun pelajar, ataupun expatriate (pengusaha ataupun orangorang profesional yang bekerja di luar negeri). Orang Indonesia bisa menjadi batu loncatan untuk penjangkauan orang lokal dan membangun rumah doa/menara doa. Contoh: gereja-gereja Indonesia di Malaysia (semenanjung, BCM=Bethany Church Malaysia), mayoritas diisi oleh pekerja-pekerja Indonesia yang bekerja di Pabrik maupun rumah tangga. Gereja-gereja Indonesia di Hongkong mayoritas adalah pekerja rumah tangga (BIC=Bethany International Church). Gereja Indonesia di Manila, Bangkok, Ho Chi Minh maupun Yangoon, diisi oleh pengusaha dan pekerja professional. Gereja-gereja Indonesia di Amerika, mayoritas adalah pelajar-pelajar Indonesia yang bersekolah di sana (BCC=Bethel Church California).

Penjangkauan orang lokal sebagai cross-cultural mission. Misionaris Indonesia dipersiapkan belajar bahasa lokal dan mulai menjangkau. Contohnya adalah BCC = Bethany Church Cambodia, yang isinya $100 \%$ anak-anak muda Khmer. BCM yang ada di Sarawak mayoritasnya adalah orang Iban, sementara BCM yang ada di Sabah mayoritas adalah orang dusun Kadhazan.

\section{a. Misi Suku Terabaikan}

Suku terabaikan atau unreached people group adalah suku-suku yang ada di sekitar kita bahkan di sekitar gereja, tetapi tidak 
terpikirkan untuk dijangkau. Contoh: suku Melayu di Kepulauan Riau. Suku ini adalah mayoritas di Batam dengan populasi sekitar 33\% dari total penduduk di Kepulauan Riau. Usia Injil masuk ke daerah kepulauan ini sudah lebih dari 183 tahun, ${ }^{22}$ tetapi jumlah orang Melayu yang menerima Injil hanya hitungan jari. Hal ini sama dengan orang Betawi di Jakarta dan orang Sunda yang ada di Jawa Barat. ${ }^{23}$ Mayoritas suku terabaikan adalah "kedar." Penjangkauan yang paling efektif bagi kaum ini adalah melalui CPM (Church Planting Movement, kegerakan penanaman gereja yang akan dijelaskan di Bab yang lain).

\section{b. Misi Suku Terasing}

Misi suku terasing adalah pengiriman misionaris untuk sukusuku yang tersembunyi dan sulit bagi transportasi. Contoh mayoritasnya adalah suku-suku yang ada di Papua. Hal yang bisa dilakukan adalah mengirim tenaga-tenaga guru misionaris, yang selain untuk menjangkau, tentunya juga untuk mendidik.

\section{c. Misi memperkuat "Kantong" Kristen}

Hal ini adalah pengiriman tenaga-tenaga misionaris untuk memperkuat daerah-daerah Kristen yang hari-hari ini "banyak" digerogoti oleh kaum Kedar. Kantong-kantong Kristen seperti: Papua Barat, Papua, Maluku, Toraja (Sulsel), Poso dan Palu (Sulawesi tengah), NTT (Kupang, Soe, flores, Sumba), Kalimantan (Barat, tengah), Mentawai (Sumbar), Nias (Sumut), Enggano (Bengkulu) perlu diperhatikan. Selain mengutus hamba-hamba Tuhan untuk membantu gereja yang ada, perekrutan anak-

22 F.Irwan Widjaja, Disertasi Doktoral 2015 STT Real Batam, hal. 2.

23 Lihat penjelasan unreached/terabaikan di catatan kaki hal. 38. 


\section{MISIOLOGI}

anak muda dari daerah-daerah tersebut untuk dilatih di pusat pelatihan misi di Batam dan selanjutnya di utus kembali ke daerah tersebut sedang dilakukan.

\section{Strategi Yesus Menjangkau Orang Yang Hilang}

Dalam 2 Petrus 3:9 dikatakan, "Tuhan tidak lalai menepatijanji-Nya, sekalipun ada orang yangmenganggapnya sebagai kelalaian, tetapi Ia sabar terhadap kamu, karena Ia menghendaki supaya jangan ada yang 'binasa', melainkan supaya semua orang berbalik dan bertobat."

Untuk berbalik dan bertobat mereka harus berseru kepada nama Tuhan. Kerinduan Bapa surgawi adalah supaya jangan ada yang binasa. Tugas gereja Tuhanlah untuk memberitakan kabar baik, sebagaimana dalam kitab Roma 10:13-14, "Sebab, barangsiapa yang berseru kepada nama Tuhan, akan diselamatkan. Tetapi bagaimana mereka dapat berseru kepada-Nya, jika mereka tidak percaya kepada Dia? Bagaimana mereka dapat percaya kepada Dia, jika mereka tidak mendengar tentang Dia. Bagaimana mereka mendengar tentang Dia, jika tidak ada yang memberitakan-Nya?"

Penjangkauan dan pengutusan yang paling efektif telah dilakukan Tuhan Yesus. Alkitab mencatat bahwa Yesus mengutus para murid tiga kali (Mat. 10:5-15, Luk. 9:1-6, dan Luk. 10:1-22) pada saat yang berbeda dan dengan menggunakan strategi yang sama setiap kalinya.

Yesus mengajarkan ada orang-orang damai yang sudah dipersiapkan untuk merespons kabar baik (orang damai = orang yang disiapkan Tuhan; contoh: Kornelius). 


\section{Ciri ciri Orang Damai}

Orang orang "damai" dari berbagai latar belakang kepercayaan mempunyai ciri sebagai berikut:

a. Mereka adalah orang-orang yang terbuka dan menyambut

b. Mereka lapar akan hal-hal rohani

c. Mereka membuka keluarga/kelompok/masyarakat mereka kepada hal-hal rohani

d. Mereka tertarik ketika Anda membuat pernyataan rohani

e. Mereka memberikan tanggapan dengan pernyataan rohani

f. Mereka mengajukan pertanyaan kepada Anda (tidak hanya memberi tahu Anda pendapat mereka, tetapi mau tahu mengenai pendapat Anda)

g. Siap menolong Anda dan orang-orang lain, bukan hanya mau ditolong

h. Mereka menanggapi undangan Anda untuk membuka oikos mereka agar dapat belajar langsung dari perkataan Allah (Kadang-kadang mereka melakukan ini dengan mengundang Anda dalam keluarga mereka, kadang-kadang Anda dapat berbagi kepada mereka dan mereka akan membagikannya kepada keluarga mereka. Namun, jika mereka tidak membagikannya kepada keluarga mereka, berarti Anda harus berhenti berbagi dengan mereka, dan mencari "orang damai" yang sejati) 
i. Mereka terima kebenaran dari Tuhan (biasanya belum tentu sampai selesai belajar cerita-cerita dari Alkitab dan diundang berkomitmen)

j. Reputasi kuat (bisa reputasi baik atau jelek, tetapi keduanya reputasi kuat)

Dengan kata lain orang orang damai adalah orang orang terbuka, haus akan kebenaran dan mereka juga akan berbagi kepada orang lain.

\section{Metode Mencari Orang Damai}

a. Mencari Orang Damai-Ceritakan Kesaksian Anda

- Kesaksian Hidup

- Bagaimana hidup Anda sebelum Yesus

- Apa yang terjadi yang membawa Anda kepada Yesus

- Bagaimana hidup Anda sekarang sesudah kenal Yesus

b. Dengan bahasa dan gaya yang natural

c. Siapkan cerita kesaksian yang singkat

d. Memerhatikan respons dan pertanyaan

e. Membagi sesering mungkin

2. Mencari Orang Damai lewat Kebenaran tentang Isa dalam "Kitab Suci kaum Kedar" (contoh seperti dalam Ali Imran 42-55)

3. Mencari Orang Damai lewat cerita-cerita tentang para Nabi dari Taurat 
Orang Damai dalam Alkitab

\begin{tabular}{|c|c|}
\hline Matius 8:5 & Perwira \\
\hline Matius 9:27-29 & Orang Buta \\
\hline Matius 9:9-13 & Pemungut Cukai \\
\hline Markus 5:120 & $\begin{array}{l}\text { Orang Gerasa yang Dirasuki Roh } \\
\text { Jahat }\end{array}$ \\
\hline Lukas 7:11-17 & $\begin{array}{l}\text { Anak Janda yang Dibangkitkan } \\
\text { dari Kematian }\end{array}$ \\
\hline Lukas 19:1-10 & Zakheus Pemungut Cukai \\
\hline Yohanes 1:41-42 & Andreas Membawa Petrus \\
\hline Yohanes 1:43-50 & Filipus Membawa Nathanael \\
\hline Yohanes 4:1-26 & Wanita Samaria di Sumur \\
\hline Yohanes 4:47-53 & Pegawai Pemerintah \\
\hline Yohanes 5:1-15 & $\begin{array}{l}\text { Orang Lumpuh di Kolam } \\
\text { Bethesda }\end{array}$ \\
\hline Yohanes 9:1-41 & Orang yang Dilahirkan Buta \\
\hline Kisah Para Rasul 10 & Kornelius \\
\hline Kisah Para Rasul 16:11-15 & Lydia di Filipi \\
\hline Kisah Para Rasul 16:16-40 & Kepala Penjara Filipi \\
\hline Kisah Para Rasul 17:6 & $\begin{array}{l}\text { Yason Memperkenalkan Kota } \\
\text { Tesalonika kepada Paulus }\end{array}$ \\
\hline Kisah Para Rasul 17:34 & $\begin{array}{l}\text { Orang Athena: Dionysius, } \\
\text { Damaris dan yang lainnya }\end{array}$ \\
\hline Kisah Para Rasul 18:1-4 & $\begin{array}{l}\text { Aquila and Priskilla (lihat Roma } \\
\text { 16:3-5) }\end{array}$ \\
\hline Kisah Para Rasul 18:7-8 & Krispus, kepala rumah ibadat \\
\hline
\end{tabular}




\begin{tabular}{|l|l|}
\hline Kisah Para Rasul 28:7-10 & Publius \\
\hline Roma16 & Berbagai Jemaat di Roma \\
\hline 1 Korintus 1:16 & Stephanus \\
\hline Filemon 1:2 & Archippus (lihat juga Kol. 4:17) \\
\hline
\end{tabular}

\section{(Endnotes)}

1 Foto foto siwa POAB angkatan I

2 Brosur Warta Yoido

3 Klipping Koran peresmian Klinik Pintu Gerbang Kasih

4 Peserta Pertemuan dunia Batam: GCPN dan GACX 10-13 Mei 2016 


\section{Dasar-dasar Firman dan Filosofi dalam Pelayanan Misi}

Setiap pergerakan misi harus mempunyai dasar-dasar
untuk melangkah yang akan meneguhkan setiap personil
di lapangan dan yakin akan panggilannya. Bab ini akan
menjelaskan dasar-dasar tersebut;

\section{Dasar Iman untuk melangkah}

Iman adalah dasar dari setiap kegerakan misi. Kitab Ibrani 11:1 berkata, "Iman adalah dasar dari segala sesuatu yang kita harapkan dan bukti dari segala sesuatu yang tidak kita lihat." Diperlukan iman untuk melangkah, iman yang mengandalkan firman Tuhan. Ketika Nuh dipanggil untuk memberitakan keselamatan sambil memprsiapkan diri membuat bahtera, Nuh memerlukan waktu 120 tahun. Ketika Abraham dipanggil untuk menjadi berkat bagi bangsa-bangsa (Kej. 12:1-3), Abraham melangkah dengan iman. Setiap panggilan, harus mempunyai dasar. Dasar yang paling dasar adalah iman. 


\title{
MISIOLOGI
}

Utusan misi dipanggil untuk menjadi berkat bagi bangsabangsa. Dasar Iman yang pertama:

\begin{abstract}
Yohanes 12:25-26
"Barangsiapa mencintai nyawanya, ia akan kehilangan nyawanya, tetapi barangsiapa tidak mencintai nyawanya di dunia ini, ia akan memeliharanya untuk hidup yang kekal. Barangsiapa melayani Aku, ia harus mengikut Aku dan di mana Aku berada, di situpun pelayan-Ku akan berada. Barangsiapa melayani Aku, ia akan dihormati Bapa."
\end{abstract}

\section{“...Tidak takut kehilangan nyawa, Tuhan yang pelihara"}

Langkah iman pertama bagi setiap anggota misi dan tim adalah untuk tidak takut kehilangan nyawa. Setiap perekrutan anggota baru yang rindu melayani, sebelum mengikuti pelatihan dan arahan lebih lanjut, harus melewati tahap wawancara terlebih dahulu. Setiap calon misionaris harus menanda-tangani surat di atas materai yang menyatakan bahwa mereka siap mati dan jika terjadi halangan dan kejadian fatal yang merenggut nyawa mereka, mereka menyadari bahwa hal itu merupakan tanggung jawab pribadi dan bukan kesalahan gereja atau badan misi. ${ }^{1}$

Dalam perjalanan sebagai Hamba Tuhan, saya mengunjungi beberapa tempat pelayanan. Suatu ketika, pada Maret 2004, saya melakukan perjalanan menuju kepulauan Aru dalam rangka KKR di lapangan yang diselenggarakan gereja GPI yang ada di Dobo. Acara itu berjalan dengan "dahsyat." Penerbangan dimulai dari JakartaSurabaya lalu ke Makasar dan Ambon. Dari Ambon, pesawat propeller (baling-baling) menuju Tual, Maluku Tenggara. Pesawat dengan kapasitas 20 orang mulanya mengangkut penumpang dengan normal, sesuai dengan bangku yang ada. Namun mulai dari Tual menuju Dobo 
Kepulauan Aru, penumpang melebihi kapasitas yang ada. Tercatat 4 orang berdiri dan 3 orang duduk di kursi tambahan berupa koper. Situasi ini membuat saya galau, mau protes takut diturunkan. Namun kalau didiamkan akan mengakibatkan kecemasan yang berlebihan. Di tambah lagi, pilot menyatakan bahwa pesawat mampu mengangkut semua penumpang dan bagi yang keberatan, pilot bersedia menurunkan. Singkat cerita pesawat dipaksakan berangkat. Hampir 1 jam, pesawat meraung-raung di landasan pacu dan terus lepas landas. Bahasa Roh yang kencang mengiringi deru suara mesin pesawat. Saya memaksakan "iman" bahwa pesawat tidak apa-apa dan akhirnya dalam keadaan tergoncang-goncang karena turbulensi ditambah kelebihan penumpang dan barang, sayup-sayup terdengar dalam batin ini Roh Kudus menanyakan sesuatu kepada saya secara pribadi: "Irwan, kamu lihat pilot ini tidak mengenal-Ku. Namun, ia tidak takut mati. Bagaimana dengan kamu? Kamu mengenal Penciptamu, apakah kamu takut mati? Masih ingat dalam benak saya, pertanyaan ini susah dijawab waktu itu, antara takut dan tidak, antara percaya dan penuh keraguan. Saya tahu Roh Kudus memaksa saya untuk mengambil keputusan, yang akhirnya saya jawab dengan terbata-bata: "Tuhan, hamba-Mu, nggak takut mati Tuhan." Sejak kalimat itu dikeluarkan dari mulut, roh keberanian seolah-olah menghinggapi saya sehingga ada kelepasan yang luar biasa.

Perjalanan yang menakutkan juga terjadi pada September 2006, dalam penerbangan dari Jakarta menuju Jambi. Pesawat yang saya tumpangi terguncang karena turbulensi. Hal ini biasa terjadi karena wilayah kepulauan Riau sering dilanda ombak besar dan ketika kapal harus membelah ombak atau berpapasan dengan ombak, perut terasa mual karena terguncang. Jadi, ketika di pesawat terjadi guncangan, saya sering membayangkan seolah-olah berada dalam kapal. Waktu penerbangan dari Jakarta ke Jambi biasanya hanya 55 menit, tetapi 


\section{MISIOLOGI}

kali ini sudah lebih 20 menit dari waktu seharusnya. Ketika saya menyadari dan melihat ke pramugari dan situasi dalam pesawat serta melongok jendela, saya tahu sesuatu yang tidak baik sedang terjadi. Saya langsung mencampakkan surat kabar yang sedang saya baca. Kepanikkan dalam pesawat sangat terasa, bahkan ada yang sampai berteriak-teriak memanggil Tuhan mereka. Dengan jelas terlihat Sungai Batanghari yang mendekat, rawa-rawa dan pohon kelapa semakin lama semakin dekat. Saya mengeluarkan ayat-ayat firman Tuhan sambil tawar menawar dengan Bapa di Surga. Semua ayat yang menjadi andalan dalam keadaan darurat pun saya keluarkan. Kitab Filipi 1:21, "Karena bagiku hidup adalah Kristus dan mati adalah keuntungan" dan Pengkhotbah 7:7. "Tuhan, kalau harus mati, saya yang untung karena sudah mengenal Kristus, tetapi Tuhan yang rugi (sedikit mengancam) karena pekerjaan Tuhan yang ditangani akan terganggu. Lalu, saya juga mengingatkan Tuhan akan waktu. Kitab Mazmur 90:10 mengatakan "Masa hidup kami tujuh puluh tahun dan jika kami kuat, delapan puluh tahun, dan kebanggaannya adalah kesukaran dan penderitaan; sebab berlalunya buruburu, dan kami melayang lenyap." Saya mengingatkan Tuhan akan firman-Nya yang berkata umur manusia 70 tahun, 80 tahun kalau kuat, "Namun, umur hamba-Mu belum sampai segitu Tuhan." Lalu penulis mengingatkan Tuhan akan firman-Nya dalam kitab Pengkotbah 7:7 "Jangan terlalu fasik, jangan terlalu bodoh, jangan mati sebelum waktumu." Dan doa terakhir secara pribadi yang saya naikkan: Tuhan Yesus, kasihani "saya", kalau "saya" mati sekarang, istri saya akan menjadi janda, ia masih muda Tuhan Yesus. Inilah doa terakhir yang saya yakini Tuhan dengar. Pesawat akhirnya mendarat secara darurat di Palembang. Segera setelah pintu dibuka, saya adalah orang pertama yang turun duluan, mengucap syukur sambil menghubungi orang-orang yang dikasihi dan juga pemimpin. Ternyata pendoa syafaat di gereja yang sedang melakukan doa dan 
puasa setiap Sabtu mengatakan bahwa sepanjang 2 jam, mereka hanya meratap dan meratap. Saya percaya ada tarikan dengan roh maut dalam peperangan rohani.

Langkah iman kedua adalah seperti yang diungkapkan dalam kitab Roma 8:31b: "Jika Allah dipihak kita siapa dapat melawan?" Ada banyak peperangan bagi setiap anggota misi yang akan diutus, baik peperangan mental secara kasat mata ataupun peperangan yang harus melawan penguasa-penguasa di udara. Hal ini perlu ditanamkan dari awal bahwa kalau Allah berjalan bersama kita, siapa dapat melawan? Sebagaimana Musa mengatakan dalam Keluaran 33:15, Berkatalah Musa kepadaNya: "jika Engkau sendiri tidak membimbing kami, janganlah suruh kami berangkat dari sini." Dengan kata lain, Musa hendak meyakinkan, kalau ia bergerak, Tuhan sendiri yang memimpin.

Dalam langkah iman yang ketiga, saya dingatkan bahwa setiap kita yang melakukan kehendak Bapa di surga dan percaya kepada Yesus akan melakukan perkara-perkara yang jauh lebih besar dari pada Yesus.

Yohanes 14:12

"Aku berkata kepadamu: Sesungguhnya barangsiapa percaya kepada-Ku, ia akan melakukan juga pekerjaan-pekerjaan yang Aku lakukan, bahkan pekerjaan-pekerjaan yang lebih besar dari pada itu. Sebab Aku pergi kepada Bapa;"

Ada banyak perkara yang jauh lebih besar yang telah kita lakukan, dari cara penjangkauan, moda tranportasi yang kita gunakan untuk penjangkauan, dan media yang digunakan. Semua itu menunjukkan perkara-perkara yang jauh lebih besar.

Selain mengerjakan perkara-perkara besar, dalam dunia misi, mengutus dan menduduki daerah adalah bagian penting. 


\section{MISIOLOGI}

Untuk itu, diperlukan keyakinan, sama seperti dalam kitab Yosua 1:3:

"Setiap tempat yang akan diinjak oleh telapak kakimu Kuberikan kepada kamu, seperti yang telah Kujanjikan kepada Musa."

Ayat ini juga saya ucapkan berulang-ulang untuk setiap tempat yang Tuhan taruh di hati.

Dalam Markus 16:17-18,

Tanda-tanda ini akan menyertai orang-orang yang percaya: mereka akan mengusir setan-setan demi nama-Ku, mereka akan berbicara dalam bahasa-bahasa yang baru bagi mereka, mereka akan memegang ular, dan sekalipun mereka minum racun maut, mereka tidak akan mendapat celaka; mereka akan meletakkan tangannya atas orang sakit, dan orang itu akan sembuh.

Pengenalan akan firman meyakinkan kita. Ketika melangkah dalam melakukan amanat Agung, kita tidak akan mendapat celaka. Tentu kita harus yakin, ketika kita punya Roh Kudus, panggilan kita menjadi berkat sampai ke ujung-ujung bumi.

Kisah Para Rasul 1:8

"Tetapi kamu akan menerima kuasa, kalau Roh Kudus turun ke atas kamu, dan kamu akan menjadi saksi-Ku di Yerusalem dan di seluruh Yudea dan Samaria dan sampai ke ujung bumi."

Dan tentu saja kita harus mempunyai iman bahwa Tuhan Yesus akan menyertai kita sampai pada akhir zaman. Penyertaan Tuhan melebihi atasan kita dan penyertaan Tuhan melebihi orang-orang yang kita kasihi karena semua terbatas tetapi penyertaan Tuhan tidak terbatas (Mat. 28:19-20). 


\section{Dasar Penerapan}

Sebagai utusan misi yang siap memberitakan kabar baik, selain dasar iman untuk melangkah, orang tersebut harus juga memiliki dasar penerapan firman Tuhan dalam hal melangkah di ladang misi. Setiap utusan misi harus mengerti bahwa mereka adalah:

\section{a). Seorang murid}

Dalam Lukas 14:26-27 dikatakan, "Jikalau seorang datang kepada-Ku dan ia tidak membenci bapanya, ibunya, isterinya, anak-anaknya, saudara-saudaranya laki-laki atau perempuan, bahkan nyawanya sendiri, ia tidak dapat menjadi murid-Ku. Barangsiapa tidak memikul salibnya dan mengikut Aku, ia tidak dapat menjadi murid-Ku."

Korban dan bayar harga adalah ciri seorang murid. Berkorban soal waktu, bahkan orang orang yang dikasihi, harus siap dilupakan, tentu tidak untuk selamanya. Namun, ada harga yang harus dibayar oleh seorang murid.

\section{b). Seorang Prajurit}

Kitab 2 Timotius 2:2-4 berkata:

"Ikutlah menderita sebagai seorang prajurit yang baik dari Kristus Yesus. Seorang prajurit yang sedang berjuang tidak memusingkan dirinya dengan soal-soal penghidupannya, supaya dengan demikian ia berkenan kepada komandannya."

Seorang utusan misi harus mengerti, selain mereka sebagai murid, mereka juga prajurit. Prajurit bukan hanya membayar harga, tetapi prajurit tidak memusingkan penghidupan pribadi. Tidak memusingkan hal-hal mengenai penghidupan dan 
kekayaan $^{1}$, tetapi percaya bahwa Tuhan akan menyediakan sesuai keperluan (Flp. 4:19, "Allahku akan memenuhi segala keperluanmu menurut kekayaan dan kemuliaan-Nya dalam Kristus Yesus"). Selain itu, prajurit tidak akan mundur untuk segala medan yang diutus.

\section{c). Seorang Duta Besar/Utusan Kristus.}

Kitab 2 Korintus 5:20 dikatakan, "Jadi kami ini adalah utusan-utusan Kristus, seakan-akan Allah menasihati kamu dengan perantaraan kami; dalam nama Kristus kami meminta kepadamu: berilah dirimu didamaikan dengan Allah."

Utusan misi sebagai utusan Kristus (ambassador) atau duta besar punya hak istimewa, yaitu punya hak imunitas atau kekebalan. Selain itu, seorang Duta Besar hanya mengurusi urusan-urusan negara yang mengutusnya dan mendapat gaji dari negara yang mengutus. Tugas utamanya mewakili kepentingan negara yang mengutus. Sebagai seorang utusan misi, ia melakukan tugas dari tempat ia berasal. Dalam hal ini, kita mewakili kepentingan Kerajaan Surga dan tugas kita adalah pendamai. Mendamaikan antara orang berdosa dengan penciptanya.

\section{Dasar untuk Survive atau bertahan}

Sebagai utusan misi, kita perlu bertahan untuk semua medan, ada yang nyaman, ada yang harus terus berjuang. Untuk itu semua, perlu roh yang perkasa. Seperti Kaleb, yang dalam masa

1 Lihat pitfall to avoid di Bab VIII. 
tuanya pun terus bersemangat mempunyai roh yang perkasa dan "spirit of fighting."

Dalam Yosua 14:11-12 dikatakan,

"pada waktu ini aku masih sama kuat seperti pada waktu aku disuruh Musa; seperti kekuatanku pada waktu itu demikianlah kekuatanku sekarang untuk berperang dan untuk keluar masuk. Oleh sebab itu, berikanlah kepadaku pegunungan, yang dijanjikan TUHAN pada waktu itu, sebab engkau sendiri mendengar pada waktu itu, bahwa di sana ada orang Enak dengan kota-kota yang besar dan berkubu. Mungkin TUHAN menyertai aku, sehingga aku menghalau mereka, seperti yang difirmankan TUHAN."

Selain memiliki "spirit of fighting" utusan misi harus mengerti betul bahwa mereka dipilih Tuhan untuk diutus, sebagaimana dalam Yeremia 1:5-10,

“Sebelum Aku membentuk engkau dalam rahim ibumu, Aku telah mengenal engkau, dan sebelum engkau keluar dari kandungan, Aku telah menguduskan engkau, Aku telah menetapkan engkau menjadi nabi bagi bangsa-bangsa.' Maka aku menjawab: 'Ah, Tuhan ALLAH! Sesungguhnya aku tidak pandai berbicara, sebab aku ini masih muda." Tetapi TUHAN berfirman kepadaku: "Janganlah katakan: Aku ini masih muda, tetapi kepada siapapun engkau Kuutus, haruslah engkau pergi, dan apapun yang Kuperintahkan kepadamu, haruslah kausampaikan. Janganlah takut kepada mereka, sebab Aku menyertai engkau untuk melepaskan engkau, demikianlah firman TUHAN.' Lalu TUHAN mengulurkan tangan-Nya dan menjamah mulutku; TUHAN berfirman kepadaku: 'Sesungguhnya, Aku menaruh perkataan-perkataan-Ku ke dalam mulutmu. Ketahuilah, pada hari ini Aku mengangkat engkau atas bangsabangsa dan atas kerajaan-kerajaan untuk mencabut dan merobohkan, untuk membinasakan dan meruntuhkan, untuk membangun dan menanam."' 


\section{MISIOLOGI}

Dipilih untuk diutus dan tidak ada pilihan bagi setiap orang percaya selain untuk melakukan setiap kehendak Bapa. Kitab Yohanes 15:16 mencatat dengan jelas kalau Bapalah yang memilih kita untuk menghasilkan buah:

"Bukan kamu yang memilih Aku, tetapi Akulah yang memilih kamu. Dan Aku telah menetapkan kamu, supaya kamu pergi dan menghasilkan buah dan buahmu itu tetap, supaya apa yang kamu minta kepada Bapa dalam nama-Ku, diberikan-Nya kepadamu. Inilah perintah-Ku kepadamu: Kasihilah seorang akan yang lain."

Kita harus ingat akan kerinduan hati Bapa, dalam 2 Petrus $3: 9$

"Tuhan tidak lalai menepati janji-Nya, sekalipun ada orang yang menganggapnya sebagai kelalaian, tetapi Ia sabar terhadap kamu, karena Ia menghendaki supaya jangan ada yang binasa, melainkan supaya semua orang berbalik dan bertobat."

Bapa menginginkan supaya setiap orang bisa diselamatkan. Jika Tuhan yang memilih tentulah Tuhan menyertai, dengan perkara-perkara yang ajaib sebagaimana dicatat dalam kitab Yesaya 28:21,

"Sebab TUHAN akan bangkit seperti di gunung Perasim, Ia akan mengamuk seperti di lembah dekat Gibeon, untuk melakukan perbuatan-Nya - ganjil perbuatan-Nya itu; dan untukmengerjakan pekerjaan-Nya-ajaib pekerjaan-Nya itu!"

Ada apa di bukit Perasim?2 Di situ Tuhan telah menolong Daud, menerobos seperti air menerobos untuk mengalahkan musuhnya dalam jumlah besar. Tuhan melakukan perkara ajaib.

2 2 Samuel 5:20, 1 Tawarikh 14:11. 
Sedangkan di bukit Gibeon ${ }^{3}$ Tuhan melakukan perkara ganjil hanya untuk menolong Yosua melawan orang Amori, Tuhan mendengar doa Yosua dengan menahan matahari untuk tidak terbenam.

Sebagai seorang hamba Tuhan dan utusan misi, saya dapat merasakan pertolongan Tuhan yang ajaib dan ganjil. Suatu ketika, saya harus melakukan perjalanan dengan istri dan pengerja untuk ibadah Natal di pulau Burung pada Desember 2006. Natal tersebut diadakan pukul 5 sore. Hanya ada satu kapal yang akan berangkat sekitar pukul 12 siang dari pelabuhan domestik Sekupang, pulau Batam. Kami pergi berempat; saya dan istri, pemimpin pujian dan seorang pemain keyboard (Alm. Mas Agung dan istri). Kapal bergerak tepat waktu dan ketika kapal sudah berlayar kurang lebih 30-45 menit, ada pemeriksaan karcis. Ketika diperiksa, ternyata kami menaiki kapal yang keliru. Kapal itu tidak ke Pulau Burung melainkan ke Selat Panjang, Kabupaten Meranti, Provinsi Riau. Kami kaget karena ternyata pada pukul 12 ada dua kapal yang berangkat bersamaan. Kota terdekat yang akan kami singgahi adalah Tanjung Balai di pulau Karimun, berarti saya dan tim harus memulai perjalanan ke pulau Burung melalui Karimun.

Dengan sigap saya menelepon gembala lokal di Karimun untuk mencari jadwal speedboat ataupun carteran dari Karimun ke Pulau Burung. Informasi yang diterima, ternyata hanya ada carteran dan harganya Rp 10 juta, sedangkan uang di tangan hanya Rp. 400.000,. Saya langsung minta dicarikan carteran dari Tanjung Batu, Pulau Kundur ke Pulau Burung. Ternyata ada, tetapi harganya sekitar $R p$ 4.000.000,-. Dengan sedikit panik, saya memutuskan untuk turun di Karimun dan mengambil speedboat yang menuju Selat Belia (utara

3 Yosua 10:12. 


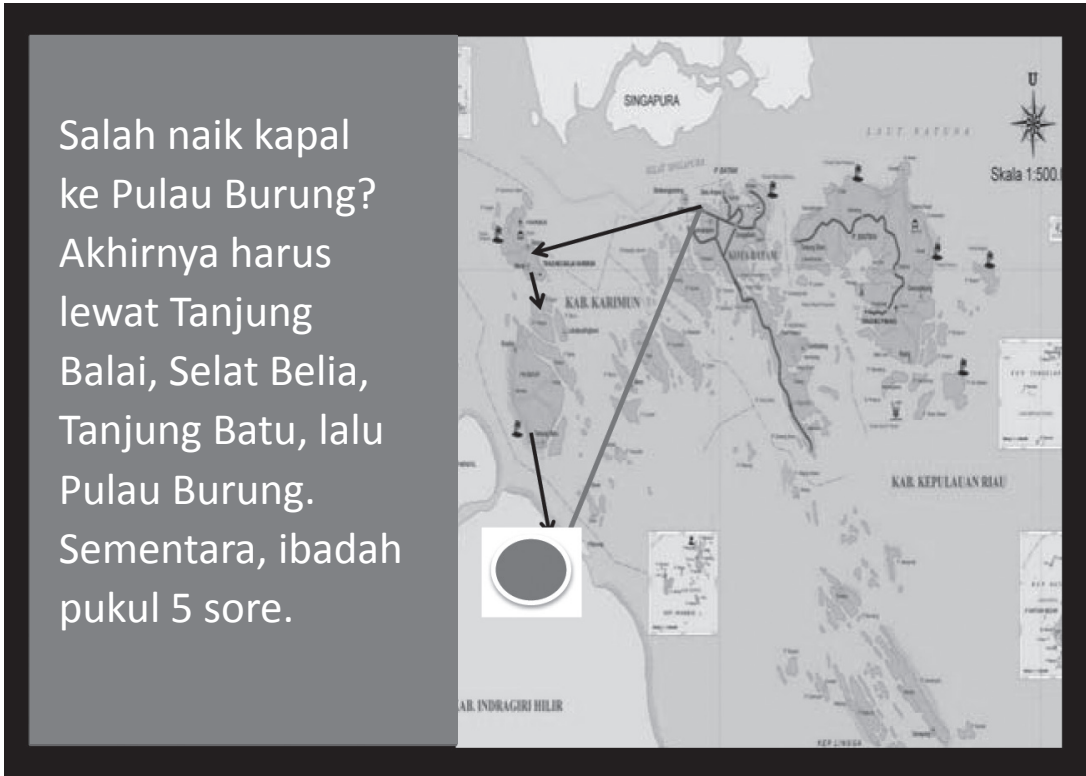

Pulau Kundur, sekitar $40 \mathrm{Km}$ dari kota Tanjung Batu). Saya berdoa meminta Tuhan melakukan perkara yang ajaib. Sambil menunggu speedboat di terminal antarpulau, saya meminta utusan misi yang ada di Tanjung Batu untuk menjemput di selat Belia. Perjalanan speedboat hanya 20 menit, tiba di Selat belia sekitar 2.30 sore. Dari Selat belia ke kota Tanjung Batu memakan waktu hampir 1 jam karena jalan desa sempit dan berlobang. Dalam keadaan darurat, staff yang menjemput mengatakan ada speedboat di pelabuhan yang siap mengantar saya dan tim ke pulau Burung. Saya menanyakan kira-kira berapa harganya dandikatakan tidaktahu. Ketikasampaidipelabuhan, orang ramai sudah menunggu di pelabuhan, ternyata ada orang-orang yang ingin ikut menumpang. Kapten Speedboat memanggil saya dan minta izin ada 11 orang yang mau menumpang. Saya kaget karena kaptennya berpakaian resmi dan bertopi resmi, berarti ini bukan sembarang speedboat, dengan gugup saya mengatakan mereka boleh 
menumpang dan setiap orang menyalami saya dan mengucapkan terimakasih dengan penuh sukacita, sementara saya bergumul berapa harga yang harus kami bayar untuk menyewa speedboat yang besar dan modern ini. Ketika semua penumpang sudah masuk, kami (saya dan tim) pun dipersilahkan masuk dan diminta untuk duduk di ruang VIP. Dengan memberanikan diri saya bertanya, sewa kapal ini berapa? Dan saya sangat terkejut mendengar jawaban sang kapten bahwa kapal ini "free", dan saya bertanya bagaimana ini mungkin? Sang kapten menjelaskan kalau kapal ini disewa orang dari Lagoi (Bintan resort) menuju ke Tanjung Batu dan karena hari sudah sore dan mereka takut kemalaman di jalan, mereka istirahat di Tanjung Batu, tetapi mereka mendengar ada yang mau ke Pulau Burung. Mereka siap mengantar karena mereka (Kapten dan kru) mau tahu letak Pulau Burung. Mendengar hal itu, kami lega. Saya tahu Tuhan sedang melakukan perkara yang ajaib. Sang Kapten pun menanyakan letak pulau burung kepada kami. Saya pun menelpon staf gembala yang ada di Pulau Burung untuk melambai-lambai di pinggiran dengan kain berwarna, supaya kapten bisa melihat dari jauh. Singkat cerita, kami tiba di Pulau Burung 4,45 sore. Saya sempat mandi dan mengucap syukur. Tepat jam 5.00 sore, saya sudah ada di ruang ibadah. Tuhan sanggup melakukan perkara ajaib hanya untuk menolong "kami" supaya firman-Nya boleh disampaikan kepada orang-orang yang rindu untuk mendengar.

Ada banyak perkara ganjil yang saya alami karena pertolongan Tuhan.

Suatu ketika, saya diundang untuk menghadiri pertemuan Hamba-hamba Tuhan di negara-negara Pasifik Selatan di Papetee French Polynesia. Sebelum berangkat, saya ada pertemuan misi pada 4 September 2004. Jadi seluruh tim pelayanan di Malaysia dan Thailand hadir di Singapura karena keesokan harinya ada "Minggu Misi". 


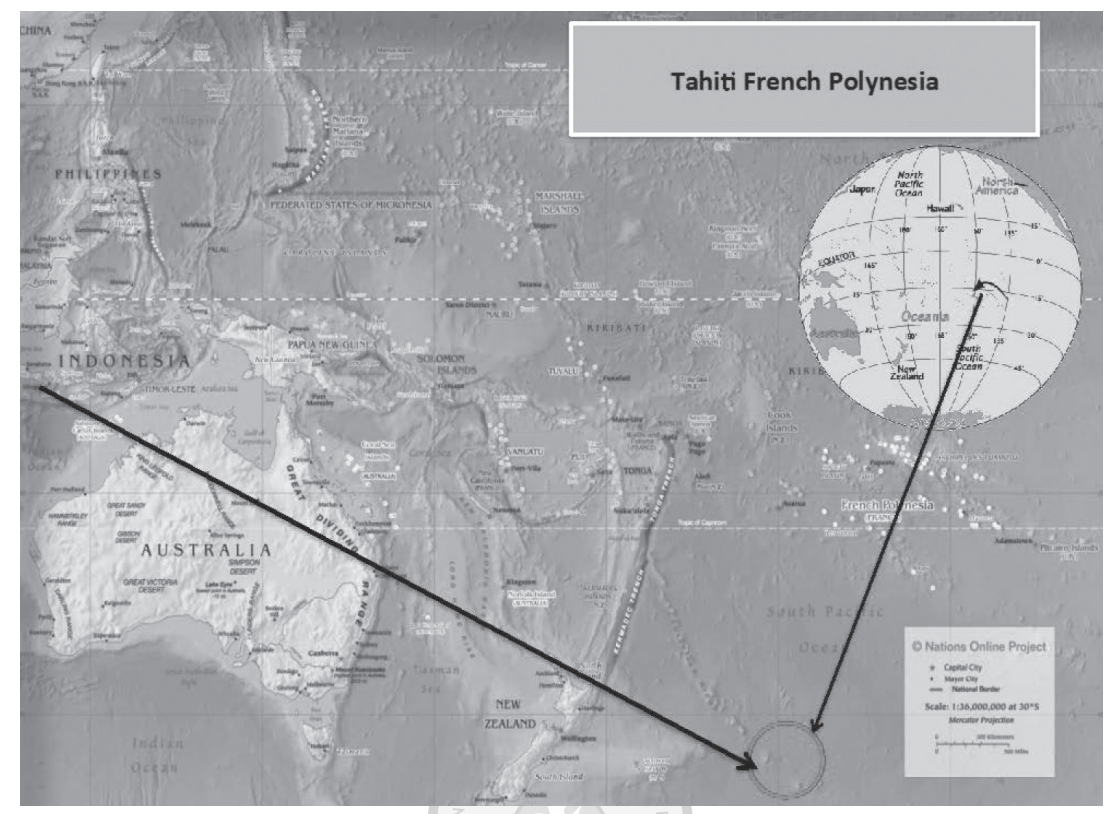

Saya masih ingat malam sebelum berangkat, Roh kudus mengingatkan untuk membawa uang rupiah. Saya bertanya kepada tim misi apakah ada yang memiliki uang rupiah? Hanya ada staf gembala utusan misi dari Bangkok (Ps. Olga Siahaan) yang memiliki 7 lembar uang seribu rupiah, semua diberikan kepada penulis. Pada 4 September malam harinya, saya berangkat menuju Selandia Baru dan tiba pada 5 September siang hari. Sore hari pada 5 September, kami berangkat menuju Papetee Tahiti French Polynesia dan mendarat pada 5 September malam. Saya sedikit bingung, bagaimana cara menghitungnya?

Saya sedikit terkejut ketika mengetahui bahwa biaya hidup sangat mahal. Kebetulan uang di kantong hanya $\$ 300$ (tiga ratus dolar Singapura). Menurut hitungan kasar, uang ini akan habis dalam waktu 4-5 hari, sedangkan acara selama 10 hari(sepiring nasi goreng 
dan minum memerlukan biaya US\$23). Saya memutuskan puasa setiap hari sampai pada hari-hari terkhir baru akan makan. Tentunya hal itu disesuaikan dengan uang yang ada. Pada hari ke tiga puasa, Tuhan mulai membuat mukjizat yang ganjil. Orang mulai bertanyatanya di manakah Indonesia, maklum bagi mereka yang dari negara negara Pasifik Selatan seperti: Tuvalu, Kiribati, Samoa, New Caledonia, Cook Island, Vanuatu, Fiji, Salomon Island, Nauru dll, Indonesia sangat asing di telinga mereka. Agak sedikit repot bagi saya untuk menjelaskan secara detail sehingga saya memberi mereka mata uang rupiah Indonesia sambil menjelaskan bahwa ini tidak ada artinya bagi mereka, tetapi berarti bagi orang Indonesia karena hanya 10 cents US\$ bagi mereka bahkan kurang. Ketika saya memberi mereka seribu rupiah, secara spontan mereka memberi mata uang mereka, ada yang 20, 100, 50 dengan beragam-ragam mata uang. (Perlu diketahui, mata uang negara-negara Pasifik biasanya sama atau lebih besar dari mata uang US\$). Setelah semua rupiah habis, saya melihat ada banyak mata uang dan Tuhan mulai mengingatkan saya, tanggal berapa hari itu? Dan hari apa? Hari itu adalah tanggal 9 September 2004, tetapi penulis lupa hari apa? Roh Kudus mengingatkan kalau hari itu adalah hari saat saya menyerahkan hidup sebagai Hamba Tuhan, dan hari itu adalah tahun Sabath atau tahun ke tujuh saya menjadi Hamba Tuhan dan Tuhan memberi bonus khusus. Saya berlutut dan mengucap syukur untuk tangan Tuhan yang ajaib yang sanggup melakukan perkara ganjil. Dengan uang yang ada, saya bisa mengikuti tour ke Bora-bora Island yang sangat terkenal. Saya bisa membeli oleh-oleh untuk istri dan masih membawa pulang uang sekitar US\$62. Sungguh Tuhan telah melakukan perkara yang ganjil hanya untuk memberkati dan menolong. 


\section{Dasar pelaksanaan}

Matius 10:16 berkata:

"Lihat, Aku mengutus kamu seperti domba ke tengah-tengah serigala, sebab itu hendaklah kamu cerdik seperti ular dan tulus seperti merpati."

Ayat ini adalah dasar dari seluruh pelaksanaan tim misi untuk melangkah, diutus sebagai domba di tengah-tengah serigala. Mari kita melihat karakteristik dari binatang-binatang tersebut:

Domba: Mamalia ini dipilih bahkan menjadi simbol Tuhan Yesus sebagai Anak Domba. Kata domba muncul sebanyak 612 kali mulai dari kitab Kejadian pasal 4 sampai kitab Wahyu pasal 22. Dalam dunia perdombaan, domba dibagi dalam lima kategori menurut definisi yang ada:

a. Domba Solitari ${ }^{4}$, yaitu domba yang suka hidup menyendiri atau domba tunggal. (Bukankah banyak dari manusia yang suka menyendiri, mengasihani diri sendiri? Mungkin terlalu "lebay" istilah modernnya).

b. Domba Hermit ${ }^{5}$, yaitu domba yang sering membawa teman-temannya menyimpang ke arah jalan lain.

4 Solitary: living alone; avoiding the society of others or characterized by the absence of companions (Dictionary.com., disadur Februari 2017).

5 "A source of trouble were the wild hermit sheep. These had dodged successive musters, often had two or three years" growth of wool, and because of this were nearly wool blind. (English Oxford living dictionary). 
Dalam kumpulan penggembalaan, biasanya ada 1 atau 2 jenis domba hermit.

c. Domba Wandering ${ }^{6}$ yaitu domba yang bulunya jarang di potong yang mengakibatkan bulu-bulu menutupi semua permukaan tubuh, wajah, dan kepala. Sering kali, domba Wandering diumpamakan dengan jemaat yang sudah tidak bisa mendengar nasihat bahkan kebal terhadap firman Tuhan.

d. Domba Judas ${ }^{7}$ adalah kategori domba yang sering menjerumuskan kelompok-kelompok domba keluar dari jalur pengembalaan dan cenderung untuk melompat dari tebing-tebing curam yang mengakibatkan kematian.

e. Domba Contented (domba jinak) adalah jenis domba jinak yang dengar-dengaran akan suara gembala.

Domba sebagai binatang ternak juga merupakan hewan yang dipersembahkan sebagai kurban. Tuhan Yesus mengumpamakan jemaat sebagai kawanan domba dan Dia sendiri sebagai Gembala. Namun, Dia adalah Anak Domba Allah. Apa keistimewaan domba dari binatang lainnya? Domba adalah binatang yang hidup dalam kumpulan dan sangat tergantung penuh kepada gembala. Binatang yang taat akan suara gembala

6 Sering dikaitkan dengan Matius 18:12-13 karena tidak dengar-dengaran akhirnya tersesat.

7 "Judas Sheep". The "Judas Sheep" is a big pet "wether" (a castrated male) who leads the sheep from the bottom pen area, up the ramp to the top "killing floor". The poor sheep are totally unaware of what awaits them as they blindly follow on. Once up the top, the trap door is opened for the "Judas Sheep", and he trots away, and back down to the bottom pen area to lead another group of sheep to their destiny. From Forerunner Commentary, Bible Tools. 


\section{MISIOLOGI}

dan hanya tergantung kepada gembalanya. Binatang yang tidak memiliki alat bela diri secara spesifik. Domba hanya tahu mengembek waktu lapar, susah, dan senang. Ketika dalam bahaya, domba hanya tahu mengembek.

Sebagai utusan misi, kita diingatkan betul bahwa kita harus bergantung penuh dengan gembala Agung. "Akulah gembala yang baik. Gembala yang baik memberikan nyawanya bagi domba-dombanya" (Yoh. 10:11); "Akulah gembala yang baik dan Aku mengenal domba-domba-Ku dan domba-domba-Ku mengenal Aku, sama seperti Bapa mengenal Aku dan Aku mengenal Bapa, dan Aku memberikan nyawa-Ku bagi domba-domba-Ku" (Yoh. 10:1415). Di situ jelas dinyatakan Tuhan mengenal siapa kita. Yesus mengenal domba-domba-Nya. Artinya, Dia mengerti kita, kelebihan dan kekurangan, kelemahan dan tempat kita sering kali gagal. Tuhan Yesus sungguh mengetahuinya.

Serigala: binatang buas keluarga Karnivora (pemakan daging) ini hidup bergerombol. Hewan yang kuat, pintar, berani, dan ganas memiliki dua strategi dalam menangkap mangsa. Sebagai seorang ekolog satwa liar ${ }^{8}$ saya mengerti betul tentang serigala. Hal yang pertama ia akan menyergap mangsa yang sendirian. Hal yang kedua, ia akan menyergap mangsa yang lemah karena sakit, tua, atau terlalu muda. Serigala akan bekerja dengan cepat dan tepat, mengacaukan gerombolan domba ataupun mangsa yang akan menjadi target sehingga panik. Ia berburu dalam kelompok dan jika tidak ada kesempatan untuk melumpuhkan sasaran, serigala akan menunggu waktu yang tepat. Ketika mangsa sudah didapat, tentu sudah tidak ada ampun lagi. Berani

8 S1 penulis lulus dari Wildlife Ecology Management dan Research dari Oklahoma State University, USA pada 1989. 
menunggu dengan sabar pada saat yang tepat adalah kelebihan serigala.

Yeremia 5:6, perusak; Kejadian 49:27, menerkam dan memangsa; Habakuk 1:8, keganasan; Yehezkiel 22:27, menerkam dan membinasakan; Lukas 13:32, lalim dan tipu muslihat; Kisah Para Rasul 20:29, musuh; Yohanes 10:12, mencerai beraikan; Yeremia 5:6, musuh yg bengis.

Ular: Binatang melata ini hampir ada di semua lapisan benua, kecuali di Kutub Selatan. Ular adalah binatang melata yang sanggup beradaptasi di semua keadaan. Ia ada di hutan, di ladang, bahkan di gunung, di air, dan di padang gurun. Ular adalah binatang yang cerdik. Ia menangkap musuh dengan menunggu dan menyergap, menyamar atau kamuflase, dan dapat menangkap mangsa yang jauh lebih besar dari ukurannya. Ular sanggup mengikuti mangsa dengan sabar dan menunggu waktu yang tepat, itulah keunggulannya. Ular merupakan binatang pemangsa yang hampir jarang gagal mendapatkan mangsa.

Ular hadir dalam penciptaan awal manusia sampai pada kitab Wahyu. Dari awal penciptaan sampai akhir zaman, ular memainkan peranan penting. Belajar dari kecerdikan ular, hendaknya sebagai utusan misi pun harus bisa menyesuaikan dengan tempat pengutusannya. Situasi dan tempat bukanlah kendala. Dengan kecerdikan kamuflase, sergapan, bisa yang mematikan, dan kesabaran dalam penyesuaian tempat, ular jarang mengalami kegagalan. Demikian juga hendaknya utusan misi dalam pengutusan. 


\section{MISIOLOGI}

Merpati: Keluarga aves (burung) ini termasuk rumpun burung jinak. Merpati sering dipakai sebagai simbol perdamaian. Ia merupakan binatang pertama yang membawa kabar baik bagi Nuh, pertanda air mulai surut dan ada kehidupan. Kitab Kejadian 8:11 berkata:

"Menjelang waktu senja pulanglah burung merpati itu mendapatkan Nuh, dan pada paruhnya dibawanya sehelai daun zaitun yang segar. Dari situlah diketahui Nuh, bahwa air itu telah berkurang dari atas bumi."

Merpati menunjukkan binatang pekerja keras, yang berani terbang jauh hanya untuk membawa berita, bahkan merpati sering digunakan sebagai pembawa surat dalam perang. Hal ini menunjukkan merpati merupakan binatang yang berani ambil risiko. Selain itu, merpati adalah burung yang setia, baik pada pasangannya maupun kepada majikannya. Burung merpati tidak memiliki empedu-lambang kepahitan-sehingga merpati tidak pernah kepahitan.

Seorang misionaris/utusan misi adalah utusan yang senantiasa mengandalkan Tuhan, baik dalam keadaan normal atau biasa-biasa maupun dalam keadaan yang memerlukan pertolongan Tuhan. Dia mengerti betul bahwa ia diutus di tengah-tengah lingkungan yang siap menyerang kedagingan kita, baik secara fisik maupun alam roh. Perihal utusan misi yang memasuki penguasa teritori yang berbeda sudah diperingatkan oleh Firman Tuhan.

Efesus 6:12 berkata,

"karena perjuangan kita bukanlah melawan darah dan daging, tetapi melawan pemerintah pemerintah, melawan penguasa penguasa, melawan penghulu penghulu dunia yang gelap ini melawan roh roh jahat di udara." 
Utusan misi/misionaris senantiasa akan berhadapan dengan penguasa udara (roh jahat) dan penguasa teritori. Mereka juga akan berhadapan dengan orang-orang yang secara fisik menolak, bereaksi bahkan menjadi musuh secara nyata. Untuk itu, utusan misi harus cerdik tetapi juga tulus. Strategi pendekatan dan "personal approach" harus berfungsi dan berhikmat benar.

\section{Studi Kasus: Perjalanan Misi membuka mata rohani melihat Penguasa Alam Roh yang mengikat}

Pengalaman bersama tim misi ketika melakukan perjalanan misi ke Asia Selatan (India dan Nepal) dan Tibet pada 21 Juli-2 Agustus 2014.

Perjalanan misi kali ini sangat menentukan pengutusan missionaris baru di bagian Selatan Asia. Setiap tahun, tim misi Bethany Church Singapore yang saya komando menentukan satu negara baru sebagai ladang pelayanan baru. Sebagaimana budaya pengutusan, mission exposure sangatlah penting dilakukan untuk melihat keadaan wilayah tertentu dan selanjutnya bersama tim akan didoakan daerah-daerah mana saja yang menjadi target pengutusan kami. Mission trip 2014 memilih Asia Selatan. Daerah yang akan dikirim utusan adalah antara India atau Nepal. Sedangkan ke Tibet, kami ingin berdoa keliling di base camp pegunungan Himalaya. Menurut sepengetahuan saya dan dari sumber-sumber profetik, penguasa Tibet adalah penguasa Asia. Perjalanan dimulai dari India, Nepal, dan Tibet.

\section{India}

Saya sudah menginjakkan kaki di India untuk kelima (5) kalinya. Tim misi kali ini terdiri dari 31 mission pastors, pengerja dan juga kandidat calon misionaris. Kami tiba di Kalkuta pada 22 Juli 2014 pagi hari dan melanjutkan penerbangan konekting menuju New delhi. 


\section{MISIOLOGI}

Setibanya di New Delhi, tim boleh melihat kesenjangan peradaban antara Kaya dan Miskin begitu mencolok dan antara Kasta dan non kasta seperti suku Dalit. ${ }^{9}$

Di India, hal yang kami lakukan hanya berdoa keliling sehingga tim boleh menyaksikan "pandita" kuil Siwa berjalan kaki sambil memikul "gentong alumunium." Ternyata mereka adalah orang-orang dari berbagai daerah yang pulang dari sungai Gangga membawa air suci. Mereka harus berjalan kaki karena takut air tercemar. Perjalanan itu sering kali memakan waktu berhari-hari dan berminggu-minggu untuk tiba pada tempat asal (perlu dicatat bahwa untuk menuju ke sungai Gangga, mereka boleh menaiki kendaraan apa pun). Alasan yang mendasar adalah air itu dianggap suci dan dengan menumpangi kendaraan akan tercemar dan menjadikan air itu tidak kudus. Air akan digunakan untuk memberkati rumah tangga, usaha, keluarga, bahkan jemaat-jemaat yang perlu dikuduskan. Dalam abad modern seperti ini, ketika masih ada budaya yang menghormati sesuatu yang leluhur mereka percayai dan tetap mempertahankannya merupakan hal yang menakjubkan. Orang India sangat menghargai dewa-dewi mereka. Hampir ada sejuta tuhan. Ketika penulis saya kepada mereka tentang Yesus yang saya punya, mereka hanya mengatakan " hmm. We can add to our gods, it's okay to put one more. Since we have million of gods, one more is okay." (kami akan menambahkan Yesus

9 Dalit adalah suku non-kasta yang sangat rendah kedudukannya dibanding suku-suku dengan 4 kasta. (In Hindu ritual ranking system of castes known as Varna and under this Verna there are four divisions. Brahmins, Kshatriyas, Vaishyas, Shudras, But the chamars/Dalit will not include in Varna or thefour categories mentioned above but it comes as untouchable communities or dalits among the people. Now they are classified as a Scheduled Caste undermodern India's system of positive discrimination. This Chamars are found mostly in the Northern states of India, in Pakistan and Nepal By Ethnography Report of Chamars of India and special attention to North India By C.M. Edward Jesudhas, BIU Singapore). 
sebagai salah satu dari tuhan kami karena kami sudah memliki satu juta tuhan/dewa-dewi, tidak masalah bagi kami).

Mereka menghabiskan uang yang banyak untuksetiap hari raya agama. Hidup di bawah garis kemiskinan tidak masalah bagi mereka. Hal yang terpenting mereka dapat menyenangkan tuhan-tuhan mereka. Mereka tidak sadar kalau mereka hidup di bawah kutuk.

\section{Nepal}

Setelah beberapa hari di India, kami melanjutkan perjalanan menuju Katmandhu Nepal. Setibanya di penginapan, kami langsung mempersiapkan diri untuk melakukan doa keliling di tempat-tempat penyembahan berhala Bhaktapur Durbar Square. Tim kami juga menuju tempat yang paling tinggi yaitu Nagarkot di Katmandhu. ${ }^{2} \mathrm{Di}$ Katmandhu, tim melihat seseorang yang mati, harus dibakar sendiri oleh keluarganya di pinggiran sungai Bagmathi. Jika yang mati berasal dari keluarga yang berada, pengantarnya akan ramai. Setelah dibakar, abu dari yang mati akan didorong/dibuang langsung ke sungai. Padahal, air dari sungai ini juga dipakai untuk kebutuhan sehari-hari. Melihat kenyataan ini, saya dan tim hanya bisa menyimpulkan, orang yang tidak dalam Tuhan, matanya dibutakan. Mereka melakukan segala sesuatu tanpa mengerti kebenaran (Setahun setelah perjalanan dan doa keliling di tempat-tempat penyembahan berhala, kami bisa melihat Nepal terbuka bagi Tuhan melalui Gempa yang dasyat, Mercy Mission Relief, dengan tema Real Care masuk ke pusat pusat gempa membantu pelayanan kemanusiaan. ${ }^{3}$ Saat ini, kami sedang melakukan persiapan perintisan penanaman gereja).

\section{Tibet}

Memasuki Tibet, saya merasakan peperangan tingkat tinggi ketika di perbatasan. Dalam kondisi lapar, tim singgah di restoran yang ada. 


\section{MISIOLOGI}

Sebagian langsung ke toilet. Begitu juga istri saya. Namun ketika di toilet, istri saya, Nana Sendy melihat ada dua peti mati yang ditaruh di dekat toilet. Hal itu membuat dirinya ketakutan dan segera lari ke atas (ia tidak member tahu hal ini sampai kami mengalami serangan roh jahat pada malam harinya. Setelah itu, barulah hal ini disampaikan). Setelah makan, tim langsung ke bus karena kami mengejar untuk tiba di tempat penginapan pertama. Tour guide mengingatkan kepada seluruh tim untuk tidak menyanyi (Pujian dan penyembahan) karena tempat akan semakin tinggi dan oksigen akan berkurang. Sebelumnya, tour guide telah membagikan kami "scarf" atau selendang putih. Hal itu dipakai dan dililitkan di leher kami. Ternyata kami tahu, selendang ini sudah didoakan di "monastri"/tempat sembahyang dan sudah dipersembahkan terlebih dahulu.

Kami sampai ke tempat peristirahatan sekitar pukul 11.45 malam, semua tim langsung beristirahat karena kelelahan. Menjelang pukul 1 pagi, seluruh tim diserang penyakit ketinggian "altitude sickness", yaitu kepala terasa sakit karena kurangnya oksigen. Sakit itu berkelanjutan sehingga membuat paru-paru memaksa mengambil oksigen dan menekan diafragma perut. Hal itu menekan lambung dan membuat seseorang merasa sakit perut maag yang akut dan ujungnya akan muntah dan buang air besar berturut turut (Kalau muntah dan buang air besar, itu tandanya sudah gawat). Malam itu, tim yang 29 orang (dua orang telah memutuskan pulang terlebih dulu dari Katmandhu), merasakan situasi yang sangat sulit. Empat belas orang merasakan bahwa mereka akan mati di tempat (roh maut menguasai perasaan dan beberapa mimpi buruk). Saya sebagai ketua tim, malam itu juga sakit kepala dan sesak napas. Malam itu, saya merasakan penglihatan atau mimpi sehingga saya membangunkan istri untuk menemani karena merasa "gentar". Sementara istri juga tidak bisa bangun karena kepala terlalu berat dan sakit. Setelah itu, saya merasakan didatangi makhluk hitam besar dengan 6-8 tangan dan 
wajah seram yang mendatangi dan mencekik saya. Dengan sisa-sisa tenaga, saya berteriakdan menghardik, mengusir, dan menengkingnya. Saya hanya mendengar suara yang mengatakan: "Kamu lupa ya. Dua belas tahun lalu kamu juga berhadapan denganku? (12 tahun sebelumnya, ketika mengunjungi Katmandhu dan perbatasan Tibet, saya mengalami peperangan rohani yang dahsyat. Sepulang dari perbatasan Tibet-Nepal, istri merasa sangat "jijik" dan tidak suka menjadi istri hamba Tuhan dan segera meminta "cerai". Pemulihan memakan waktu 4-6 bulan, tetapi hal itu kami sadari sebagai bentuk peperangan rohani. Pada waktu itu, saya tidak mengerti kalau sedang masuk dalam peperangan rohani. Namun karena malam itu diingatkan oleh roh jahat, saya jadi ingat). Dalam pergulatan roh tersebut, saya berusaha untuk mengingat ayat-ayat, tetapi hal tidak muncul dari pikiran. Baru setelah berbahasa Roh kencang-kencang, ayat ini keluar: Mazmur 121:1-8,

"Aku melayangkan mataku ke gunung gunung; dari manakah akan datang pertolonganku? Pertolonganku ialah TUHANyang menjadikan langit dan bumi. Ia takkan membiarkan kakimu goyah, Penjagamu tidak akan terlelap. Sesungguhnya tidak terlelap dan tidak tertidur Penjaga Israel. Tuhanlah Penjagamu, Tuhanlah naunganmu di sebelah tangan kananmu. Matahari tidak menyakiti engkau pada waktu siang, atau bulan pada waktu malam. TUHAN akan menjaga engkau terhadap segala kecelakaan; Ia akan menjaga nyawamu. TUHAN akan menjaga keluar masukmu, dari sekarang sampai selama-lamanya."

Malam itu hampir di semua kamar terjadi peperangan rohani, teriakan, tangisan, muntahan di mana-mana. Dan beberapa orang mengalami buang air besar. Saya sendiri mendapat penglihatan ada dua peti mati keluar dari sederetan kamar-kamar yang ditempati tim. Mulai dengan kejadian ini, saya tahu harus masuk peperangan rohani. Ternyata malam itu, pendoa safaat yang juga calon misionaris melihat 


\section{MISIOLOGI}

hal yang sama. Sementara sedang melakukan peperangan rohani, saya masih ingat dengan jelas penampakkan kuasa gelap yang berusaha mengagalkan perjalanan kami.

Pukul lima pagi, semua anggota tim datang menghadap dan meminta agar semua tim turun karena kondisi yang tidak memungkinkan. Akhirnya, saya memutuskan pagi itu untuk turun dari Old Tigri (populasi kota ini hanya 523 orang) dari ketinggian 4.300 meter ke kota yang terdekat, kota SHIGATSE (peperangan rohani terus terjadi). Dari kota ini, tim melanjutkan perjalanan menuju Lhasa. Di Lhasa, saya dan tim mengunjungi tempat-tempat penyembahan orang Tibet. Di atas istana "Potala", saya menemukan Wajah, the Protector of Tibet "Sakya", yang dengan jelas terlihat oleh saya ketika peperangan rohani malam pertama tiba di Tibet.

\section{(Endnotes)}

1 Tempat tertinggi di Katmandhu "Nagarkot", Berdoa dan memberkati Katmandhu

3 Foto Real care 


\section{Model dan Motif Misi'}

Medel Misi berkembang dari zaman ke zaman, dari zaman I Perjanjian Lama hingga zaman Paulus sampai zaman ini. Hari-hari ini banyak gereja yang melakukan pekerjaan misi, baik gereja-gereja luar negeri maupun gereja-gereja lokal. Jika disimpulkan dan diamati, saya menyimpulkan sebagai berikut:

\section{Pelayanan misi apa yang diharapkan?}

Mission "turis" atau misi dua dan tiga. Hal yang dimaksud dengan misi ini adalah dua hari di lapangan mengunjungi dan melihatlihat sambil bersaksi dan sisanya tiga hari berada di hotel menikmati liburan. Pendanaan misi juga dipakai untuk berlibur

1 Bab ini khusus disusun dari berbagi sumber dan bahan kuliah penulis di BIU Singapore 2011, dan pengalaman serta pengamatan sebagai ketua POAB Batam, Direktur Misi BCS Singapore, Executive Committee GCPN, dan dosen terbang STTHF Surabaya. 


\section{MISIOLOGI}

- Mission "santa" atau Misi berbagi dan menolong temporal (financial) untuk merenovasi gereja di daerah ataupun membantu para perintis di lapangan dengan keuangan yang ada tanpa mengetahui tolak ukur keberhasilan. Sering kali, bantuan bisa disalahgunakan bahkan laporan fiktif.

- Mission "rice": Misi sembako; pembagian makanan kebutuhan sehari-hari kepada yang kekurangan. Lebih cenderung ke arah sosial atau diakonia jika tidak diiringi oleh kabar baik.

- Mission "ecek-ecek": misi yang mengurbankan orang miskin, hanya mengambil gambar di tempattempat bencana atau foto-foto orang kekurangan dan mengumpulkan dana dari berbagai organisasi dan jemaat tetapi tidak disalurkan kepada yang membutuhkan.

- Mission "take \& give": Misi yang dilakukan berkala untuk menolong gereja atau kelompok tertentu yang akhirnya gereja tersebut akan berubah nama atau bergabung dengan kelompok tertentu karena sudah dibantu. Satu sisi ada penambahan gereja, tetapi di sisi lain ada yang kehilangan gereja.

- Mission Biblical based: True mission, misi yang sebenarnya mengikuti pola-pola pelayanan misi Paulus.

Misi yang sebenarnya dimulai dengan tiga pertanyaan. Sebelum kita memulai misi, biarlah kita mulai dengan pertanyaan ini: 
1. Tuhan apa kata firman-Mu terhadap manusia yang jatuh dalam dosa? Adam, dimanakah engkau? (Kej. 3:9). Ternyata Tuhan yang mencari manusia, bukan manusia yang cari Tuhan. Kitab Yohanes 15:16a berkata,"Bukan kamu yang memilih Aku, tetapi Akulah yang memilih kamu."

2. Tuhan, apa yang Engkau kerjakan di dunia? Tuhan sedang menarik banyak jiwa dari bangsa-bangsa untuk menyembah dia. Kitab Yohanes 12:32 mengatakan: "dan Aku, apabila Aku ditinggikan di bumi, Aku akan menarik semua orang datang kepada-KU."

The answer: I am drawing a people from all nations to myself to worship me.

3. Tuhan apa yang Tuhan lakukan dalam hidupku? Tuhan mau memberkati kita di bumi sehingga bisa dipakai untuk memberkati bagi bangsa-bangsa.

Kitab Kejadian 12:1-3 berkata:

"Berfirmanlah TUHAN kepada Abram: 'Pergilah dari negerimu dan dari sanak saudaramu dan dari rumah bapamu ini ke negeri yang akan Kutunjukkan kepadamu; Aku akan membuat engkau menjadi bangsa yang besar, dan memberkati engkau serta membuat namamu masyhur; dan engkau akan menjadi berkat. Aku akan memberkati orang-orang yang memberkati engkau, dan mengutuk orang-orang yang mengutuk engkau, dan olehmu semua kaum di muka bumi akan mendapat berkat."

\section{A. Misi Penjangkauan dalam Kisah Para Rasul}

Dalam Kisah Para Rasul 1:8, di sana dikatakan bahwa "Tetapi kamu akan menerima kuasa, kalau Roh Kudus turun ke atas kamu, 
dan kamu akan menjadi saksi-Ku di Yerusalem dan di seluruh Yudea dan Samaria dan sampai ke ujung bumi" (Kis. 1:8).

Menurut Tafsiran Kisah Para Rasul, kata Yunani untuk "kuasa" dalam Kisah Para Rasul 1:8 adalah "Dunamis," artinya "Kekuatan, Kemampuan" (Dinamit). Dengan demikian, hal yang dimaksud ayat tersebut adalah "Kamu akan menerima kemampuan/kekuatan (Kuasa) setelah Roh Kudus turunkeatasmu." Otoritas adalah milik gereja melalui Kristus. Kemampuan adalah Milik-Nya melalui Roh. Setiap pasal dalam Kisah Para Rasul adalah demonstrasi kemampuan Roh Kudus, bukan kemampuan manusia. Apakah kemampuan Roh Kudus itu? Dia mampu melakukan segala hal. Dia adalah Allah. Roh Kudus setara dalam keagungan, kuasa, kemuliaan, kehormatan, dan atribut bersama Bapa dan Anak. Segala sesuatu yang adalah Bapa adalah Anak. Segala sesuatu yang adalah Anak adalah juga Roh Kudus, dan Dia mampu untuk menjadi segalanya dalam gereja, yaitu Tubuh Kristus. $^{2}$

Sedangkan kata Yunani untuk "saksi" dalam Kisah Para Rasul 1:8, menurut artinya adalah "Martir." Dalamnya terdapat ide yang luas termasuk tentangan, penganiayaan, dan pencobaan demi nama dan panggilan Kristus. ${ }^{3}$

Berpijak dari Kisah Para Rasul 1:8 inilah, Gereja Mulamula mulai pergi menjadi saksi dan memberitakan Injil. Bukti kemisioneran Gereja Mula-mula dapat dilihat dari data berikut:

1. Yerusalem (Kis. 1:8; 1:4; Luk. 24:47).

2. Yudea (Kis. $2: 9,14 ; 8: 1,10 ; 9: 31-43 ; 10-11$ )

2 Kisah Para Rasul (Karawaci: Harvest Internasional Theological Seminary), hal. 12.

3 Ibid, hal.13. 
3. Samaria (Kis. 8 sampai dengan 10).

4. Ujung bumi (Kis. 11:19-26; Pasal 13 sampai dengan 28).

Pada awalnya, Gereja mula-mula hanya memfokuskan penginjilannya di Yerusalem saja. Namun penganiayaan terhadap Gereja mula-mula menyebabkan jemaat di Yerusalem tersebar ke seluruh Yudea dan Samaria (Kis. 8:1). Peristiwa inilah yang menjadikan Injil diberitakan ke daerah-daerah di luar Yerusalem (Kis. 8:4). R. Dixon ${ }^{4}$ mengatakan bahwa:

Pasal 8 ini dimulai dengan akibat pembunuhan Stefanus itu, yaitu penganiayaan yang hebat terhadap gereja Tuhan yang mula-mula itu. Kemudian, pasal 8 menceritakan beberapa peristiwa dalam riwayat seorang teman sekerja Stefanus. Stefanus dan Filipus dipilih dan dilantik menjadi diaken (pasal 6). Stefanus bersaksi, lalu mati syahid (pasal 7). Dalam pasal 8 ini, kita menyaksikan pengalaman Filipus apabila ia berani bersaksi.

ayat 1b-2-Kematian Stefanus itu dihubungkan dengan kebencian umum terhadap pengajaran kekristenan yang baru itu. Pada hari itu, timbullah aniaya besar terhadap orangorang Kristen (ay. 1). Pada masa itu, pemimpin dari pengejaran itu ialah Saul yang pada kemudian hari menjadi rasul Paulus. Saul adalah seorang pengejar yang kejam seperti rasul Iblis. Namun, Allah mempergunakan pengejaran itu untuk kebaikan. Pengejaran itu membuat jemaat Kristen berpencar-pencar.

ayat 4-Umat Tuhan Yesus yang terserak-serak itu memberitakan Injil di mana-mana di daerah itu.

ayat 5-Filipus pergi ke daerah Samaria dan mengabarkan Injil di salah satu kota di sana.

4 R. Dixon, Tafsiran Kisah Para Rasul, Cet. ke-4, (Malang: Gandum Mas, 1997), hal. 51-53. 
Bahkan, Injil juga mulai diberitakan kepada orang-orang non-Yahudi (Kis. 10, 11).Walaupun hal ini sempat menjadi pertentangan besar, tetapi akhirnya mereka menyadari bahwa kehendak Tuhan untuk Injil juga diberitakan kepada orangorang non-Yahudi; Injil harus diberitakan ke seluruh dunia. Sidang Yerusalem (Kis. 15) menjadi titik tolak bagi kemisioneran Gereja mula-mula untuk bersaksi dan memberitakan Injil ke seluruh dunia (termasuk orang-orang non-Yahudi). R. Dixon mengutip dari Penuntun ke dalam Perjanjian Baru, mengatakan:

Kendatipun Allah sudah mewahyukan kepada Petrus bahwa orang-orang bukan Yahudi harus diterima ke dalam jemaat tanpa penyunatan (pasal 10), dan para rasul serta tua-tua diyakinkan (11:18), namun suatu mazhab murid-murid orang Farisi dengan gigih terus mengajar bahwa penyunatan itu perlu (15:5). Orang-orang di Antiokhia sudah memulai kampanye untuk mengabarkan Injil kepada orang-orang bukan Yahudi tanpa menuntut penyunatan. Karena itu jemaat terpecah atas golongan-golongan yang saling bertentangan karena masalah ini. Lalu, melalui Roh-Nya, Allah memimpin rasul-rasul dalam musyawarah ini untuk membuat pernyataan yang resmi dengan suara bulat bahwa penyunatan memang tak perlu lagi bagi orang-orang bukan Yahudi. ${ }^{5}$

Setelah mereka bersidang, mereka mengutus utusanutusan resmi untuk membawa dan mengantarkan surat hasil sidang tersebut kepada jemaat di Antiokhia (Kis. 12:22-29). R. Dixon mengatakan bahwa "Jemaat di Antiokhia itu tentu bergembira sekali mendengar keputusan sidang itu. Pelayanan rohani yang mereka jalankan itu dibenarkan oleh seluruh gereja

5 Dixon, Tafsiran Kisah Para Rasul, hal.108. 
Tuhan.Kinimerekabersedia menjangkauterus ke daerah-daerah yang jauh." Gereja Mula-mula sangat bersemangat dan bahkan berorientasi dalam tugas pemberitaan Injil. Injil diberitakan dan tersebar sampai ke seluruh dunia (hingga sekarang) karena berkat kemisioneran Gereja mula-mula. Menurut Ensiklopedi Alkitab Masa Kini, jilid 1, A-L, dikatakan bahwa: "Bisa dimengerti bila gereja Yerusalem menganggap dirinya sebagai ekklesia, yang menjadi sisa Israel yang telah dipugar ("Jemaat Tuhan" yang sejati). Hal yang tidak tercatat oleh Kisah Para Rasul ialah peristiwa terjadinya di luar daerah Israel suatu kelompok campuran Yahudi dan non-Yahudi, yang disebut "ekklesia" di Anthiokia' (lihat Kis. 13:1). Demikianlah keadaannya, bukan Yerusalem, melainkan Anthiokialah yang menjadi model dari "gereja baru" yang muncul di seluruh dunia. Antiokhia menjadi batu loncatan bagi pengabaran Injil di seluruh daerah sekitar Laut Tengah."

\section{B. Misi Sebelum Kita}

Misi adalah mencari dunia yang hilang dan membawanya ke kasih dan penyelamatan Tuhan melalui Yesus Kristus. Misi juga membuat mereka bertanggung jawab dan berperan aktif melipatgandakan orang percaya dalam tubuh Kristus.

Misi lahir dari hati Tuhan, melalui penginjilan "Evangelization" yang berasal dari kata Greek "euangelion" yang artinya "kabar baik" atau "the good news"-yang boleh kita artikan juga sebagai proklamasi kabar baik dari Tuhan yang sangat mengasihi sehingga DIA perlu datang atau ber-inkarnasi.

\footnotetext{
6 Ibid, 110.

7 Ensiklopedi Alkitab Masa Kini,jil.I: A-L, cetakan ke-5, (Jakarta: Yayasan Bina Kasih, 2003), hal. 333.
} 
Ketika Kristus datang sebagai misionaris dari surga, Kristus memilih murid-murid-Nya dengan cara yang unik. Setiap murid mempunyai panggilan dan cara Tuhan memanggilnya. Sebelum memanggil keduabelas murid, Yesus berdoa semalam-malaman (Luk. 6:12-16). Yesus yang memuridkan. Dengan demikian, panggilan gereja dalam misi juga merupakan panggilan penginjilan dan pemuridan. Fungsi pemuridan adalah memimpin orang-orang kepada Tuhan dan menjadi saksi, mencari, melayani dan memberi "makan" rohani serta memberi tanggung jawab.

\section{Abad-abad Pertama}

Bicara soal misi tentu tidak terlepas dari penginjilan (PI). Belum ada teori PI yang ilmiah pada abad mula-mula. Hal yang banyak ditemukan adalah beberapa pertimbangan mengenai Gereja dan filsafat kekafiran dalam buku-buku para Apologet seperti Tertulianus atau mengenai hubungan Gereja dengan agama Yahudi, misalnya dalam karangan Yustinus Martyr. Demikian juga Bapa Gereja Agustinus membentangkan hubungan Gereja dengan Negara dan Gereja dengan kebudayaan dalam bukunya De Civitate Dei. ${ }^{8}$

\section{Abad-abad Pertengahan}

Thomas Aquinas ${ }^{9}$ (1225-1274), dalam tulisannya Summa Contra Gentiles (ajaran melawan orang kafir) utamanya menguraikan pendekatan kepada orang kafir dan Muslim. Ia menulis demikian

8 Arie de Kuiper, Missiologia: Ilmu Pekabaran Injil (Jakarta: BPK Gunung Mulia, 1996), hal.11.

9 Ibid. 
karena kedua golongan itu tidak mengakui Perjanjian Lama dan orang Yahudi yang tidak percaya Perjanjian Baru.

Raymundus Lullus ${ }^{10}$ (1235-1315) dalam PI kepada orang Yahudi dan Muslim pernah mengarang buku yang berjudul Kitab tentang Orang Kafir dan Tiga Orang Berhikmat (Kristen, Yahudi dan Muslim).

\section{Zaman Reformasi"}

Para Reformator tidak atau hanya sedikit berminat kepada pekabaran Injil, apalagi memikirkannya secara ilmiah. Bahkan ada seorang teolog Lutheran, Yohann Gerhard yang berpendapat bahwa-sehabis zaman rasuli-Pekabaran Injil bukan lagi diwajibkan kepada Gereja.

\section{Sejarah Penjangkauan}

Sampai pada 1950-an, "misi" mempunyai serangkaian makna yang cukup terbatas. Kata ini menunjuk pada:

a. Pengiriman misionaris-misionaris ke daerah tertentu

b. Kegiatan yang dilakukan oleh misionaris-misonaris tersebut.

c. Wilayah geografis dimana misionaris itu bekerja

d. Lembaga yang mengutus para misionaris

e. Dunia non-Kristen atau lapangan misi

f. Pusat yang dari padanya para misionaris itu bekerja di "lapangan misi".

10 Ibid.

11 Ibid., hal 12. 
Semua pengertian ini adalah pengertian yang baru dalam dunia misi. Sampai abad ke-16 istilah misi dipergunakan dengan acuan pada doktrin Tritunggal, yaitu pengutusan Anak oleh Bapa dan Pengutusan Roh Kudus oleh Bapa dan Anak. Lalu, kaum Yesuit untuk pertama kali menggunakan istilah ini dalam pengertian penyebaran iman Kristen di antara orangorang (termasuk Protestan) yang bukan anggota gereja Katolik. Dalam pengertian yang baru ini, misi dihubungkan erat dengan ekspansi kolonial dari dunia Barat ke wilayah yang sekarang dikenal sebagai dunia ketiga.

Misi modern diawali oleh William Carey pada 1792 dari Baptist Missionary Society (Inggris) yang melangkah ke India dengan berbagai konfrontasi dari gereja karena ia adalah seorang awam dan pembuat sepatu saja. Langkahnya akhirnya menginspirasi dan dilanjutkan oleh banyak orang seperti Hudson Taylor yang menjadi pelopor China Inland Mission (misi pedalaman; sekarang OMF International).

\section{Unreached: Suku Terabaikan}

Penduduk dunia pada Oktober 2014 adalah sekitar tujuh Miliar orang (7,3 miliar), terdiri dari 16,488 suku/ethne, dan 6.909 bahasa, 237 negara. Sementara suku yang belum terjangkau adalah sekitar 2.9 miliar terdiri dari 7.081 suku. Asia memberi kontribusi terbesar untuk orang-orang yang belum terjangkau. Populasi penduduk Asia adalah 4,2 Miliar atau 60,3\% dari total seluruh penduduk dunia. Suku yang belum terjangkau sekitar 5.189 suku bangsa (ethne). ${ }^{12}$

12 At the end of 2010, Joshua Project (www.joshua project.net) reports that 6,847 of the 16,562 peoples groups on earth have no Gospel access; that is $41.3 \%$ of all people groups are still unreached. Todd Johnson, David Barrett, \& Peter Crossing (eds.), 
Istilah Unreachead Peoples pertama sekali dipopulerkan pada Kongres Internasional World Evangelization di Lausanne, Switzerland, pada 1974. Pada saat itu MARC (Mission Advanced Research and Communication Center) membuat daftar sekitar 450 suku terabaikan (unreached peoples). Ada dua ide dalam dalam istilah tersebut:

Pertama, Ide tentang people group (suku/kelompok). Misi dengan pendekatan negara dengan negara tidak dapat dipertahankan lagi karena tidak mempertimbangkan sukusuku dalam negara tersebut. Unit dasar untuk evangelisasi bukanlah negara atau individu, tetapi sejumlah besar kelompok masyarakat. Ide kunci dalam pendekatan suku/masyarakat untuk penginjilan datang dari teori penyebaran inovasi dan informasi. Sekali Injil meresapi sebuah suku, gereja yang dapat hidup terus dibawa kepada keberadaannya oleh Roh Kudus sebagai gereja yang merupakan bagian yang akrab dengan konteksnya, memiliki kapabilitas untuk menginjilli anggotaanggota lainnya dari suku tersebut.

Keduaadalahidetentang unreached (terabaikan). Padaawal tahun 70-an, terjadi perubahan di kalangan pemimpin golongan Evangelical. Apakah kita sedang mencoba untuk menemukan masyarakat yang belum terjangkau (unreached people) atau

"Christianity 2010: A View from the New Atlas of Global Christianity." International Bulletin of Missionary Research 34.1 (January 2010) shows that global Christianity (including 60\% Roman Catholics) has declined slightly from 34.8 percent in 1910 to $33.2 \%$ in 2010 (p. 29). They also uncovered the facts that $86 \%$ of religionists globally do not personally know a Christian, and non-Christians in Asia are more isolated from Christians than in any other continent in the world ( $p .34)$. And if present trends continue, 1.95 billion (24.5\%) will still be unreached by 2025.Perhaps worse is the statistical trend that Christianity will only be $33.8 \%$ of the world's population in 2025, and only 35\% by 2050. 
masyarakat yang belum dievangelisasi (unevangelized people)? Di Lausanne, masalah unreached menjadi lebih jelas dan ditolaklah gagasan bahwa karena sebuah gereja telah ditanam dalam sebuah negara, gereja telah memenuhi mandat evangelisasinya terhadap suku-suku di negara tersebut. Telah dijumpai bahwa lebih dari dua miliar orang yang secara budaya, geografis, atau politis terisolasi dari Injil (belum mendengar Injil).

Pertanyaannya, kapan masyarakat/suku dapat disebut terjangkau? Tentu jawabannya adalah jika telah ada gereja di masyarakat tersebut dengan hasrat dan kemampuan untuk menginjili anggota lain dari kelompok itu. Secara sosiologis, ukuran dari gereja tersebut haruslah dengan anggota antara 10 dan 20 persen dari keseluruhan.Jadi dengan istilah unreached, hal yang dimaksud adalah suku atau kelompok masyarakat yang di tengah-tengah mereka belum ada dari anggota masyarakatnya yang membentuk komunitas orang Kristen dengan jumlah dan kemampuan yang mencukupi untuk menginjili anggota lainnya dari masyarakat tersebut tanpa bantuan dari luar (lintas budaya). Sementara tentang konsep "hidden people", Ralph Winter memilih frase ini untuk menunjukkan sejumlah besar dari kelompok-kelompok orang yang hampir tidak ada orang Kristen dalamnya.

\section{Kategorisasi dari Unreached People}

Penjelasan di atas membuat sejumlah ahli membuat kategori dari masyarakat yang disebut unreached people groups dalam beberapa level:

a. "Hidden peoples", yaitu masyarakat yang tidak pernah atau hampir sama sekali tidak ada orang Kristen dalamnya. 
b. "Initially reached peoples" (Masyarakat yang mulai dijangkau), yaitu masyarakat/suku yang telah diinjili dan satu persen di antaranya sudah menjadi Kristen.

c. "Minimally reached peoples", yaitu masyarakat yang sudah dijangkau Injil dan 1-10 persen hidup sebagai orang Kristen.

d. "Possibly Reached People", yaitu masyarakat yang 10-20 persen dari masyarakat tersebut telah menjadi Kristen. Jika pertumbuhan gereja cukup baik, pelayanan lintas budaya dapat dihentikan karena gereja setempat memiliki kemampuan untuk menginjili masyarakat tersebut.

\section{$\%$ CHRISTIAN}

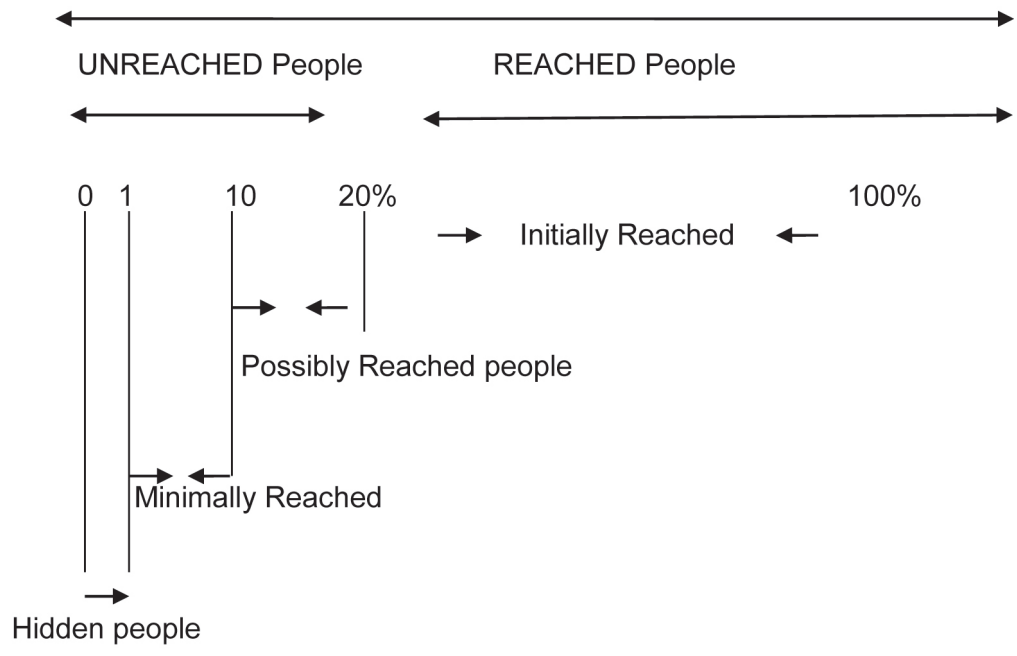

Figure 1: Definisi dari UPGs Sampai pada hari ini ${ }^{13}$

13 Diambil dari berbagai sumber definisi: Joshua Project, Mission Frontier, the unreached people groups. 


\section{B. Misi Sekarang}

Menurut pengamatan penulis dan pengalaman yang telah dilakukan di lapangan, ada lima model pertumbuhan gereja yang ada di Indonesia. Hal ini sejalan dengan pemaparan David $\mathrm{Lim}^{14}$ tentang pertumbuhan gereja di Asia yang sedang terjadi saat ini:

(1) Pertumbuhan gereja melalui program penjangkauan

(2) Pertumbuhan gereja melalui gereja sel

(3) Pertumbuhan gereja melalui penanaman gereja yang di sengaja (Intentional Church Planting)

(4) Gerakan Penanaman Gereja (Church Multiplication through church planting movements)

(5) Pengembangan Kerajaan Allah melalui kegerakan pemuridan secara holistic (Kingdom Expansion through disciple making movements)

\section{Pertumbuhan gereja melalui penjangkauan}

Kebanyakan gereja di Asia dan Indonesia, masih terfokus untuk penambahan jumlah anggota jemaat dalam gereja. Pertumbuhan jemaat menentukan besar kecilnya gereja. Kecenderungan untuk menjadi gereja "mega" dan modern, membuat gerejagereja membuat penjangkauan di mana-mana, baik melalui KKR Kesembuhan Ilahi, kunjungan ke rumah sakit, kunjungan ke rumah-rumah, pengadaan pasar murah dan pembagian sembako gratis, dan lain-lain. Program-program tersebut diharapkan

14 David Lim,"Strategies of Mission Movements in Asia Today," paper dipresentasikan pada Asian Leadership Forumdi Seoul, Korea Selatan, 25-28 Juni 2013. 
akan menarik orang yang belum ke gereja atau sudah lama tidak ke gereja ("unchurh") untuk datang ke gereja.

Hal umum lain yang dilakukan adalah pelajaran Alkitab/ Bible study diadakan, penginjilan dijalan-jalan (streetevangelism), persekutuan-persekutuan baik rumah tangga, kantor, profesi, dan klub-klub fellowship dibentuk. Promosi juga dilakukan di koran-koran, majalah, iklan di radio bahkan TV, situs web, chatrooms, dan sebagainya.

Pemakaian-pemakaian media biasa lebih gencar menjelang acara besar khusus yang dibuat gegap gempita. Jemaat dimobilisasi dan dimotivasi untuk membawa teman-teman ke pertemuan tersebut. Untuk memaksimalkan acara atau event khusus tersebut, program-program di gereja dimaksimalkan bahkan gereja juga mengundang pembicara dan kesaksiankesaksian tertentu untuk mempromosikan acara tersebut.

\section{Pertumbuhan gereja melalui pelipatgandaan sel}

Fenomena baru yang terjadi sejak 1980 adalah bangkitnya gereja sel (cell church), khususnya di "Mega-Church". Kebangkitan itu kebanyakan meniru gereja terbesar zaman itu, yaitu Gereja Yoido Full Gospel yang didirikan oleh David Yonggi Cho pada 1958 di Seoul, Korea Selatan. Dari sini lahir banyak gereja-gereja sel seperti gereja sel Keluarga Allah Solo, "churches of cells," Lawrence Khong di Singapura, "Groups of 12" (G-12) oleh Cesar Castellanos di Bogota, Colombia, Family Altar Gereja Bethany Surabaya, Cool (Community of Love) GBI Gatot Subroto Jakarta. Pertemuan sel-sel diadakan di luar hari Minggu. Dengan berjalannya waktu, kelompok sel ini menjadi kebiasaan atau menjadi program rutin dan bukan program penjangkauan. 
Motto dari sel grup biasanya "Pelipatgandaan sel". Mobilisasi dan training khusus dilakukan untuk mencari ketua-ketua sel yang berfungsi layaknya "gereja mini". Sel bisa diadakan di mana saja, tidak tergantung tempat, bisa di sekolah, kantor, restoran, dan lapangan terbuka. Kebanyakan gereja-gereja sel beraliran Pentakosta Karismatik sehingga kelompok sel pun ditekankan untuk membawa jiwa dan penginjilan, penumpangan tangan, dan doa. Dari kelompok sel, biasanya lahir gereja-gereja baru. Kelompok sel menjadi alat pertumbuhan gereja.

\section{Pertumbuhan Gereja melalui penanaman gereja yang disengaja (Intentional)}

Metode yang ketiga sering disebut "intentional church plantingsaturation church planting"atau penanaman gereja yang disengaja/dipaksakan.

Dalam hal ini, gereja lokal mulai mengutus tenaga-tenaga yang telah dididik untuk memulai pelayanan yang baru di satu daerah baru. Tujuannya adalah gereja baru. Model penanaman gereja ini biasanya melahirkan gereja satelit atau gereja ranting, biasanya sama persis dengan gereja induk. Gereja ranting atau cabang hanya "meng-copy and paste" sistem yang ada dan menerapkan seperti gereja induk. Biasanya gereja induk akan mendukung semua kebutuhan yang diperlukan sampai gereja ranting bisa mandiri. Namun bagi penanam gereja independen (aliran Pentakosta), kebanyakan mereka akan hidup dari iman dan merintis sampai gereja itu bisa mendukung hamba Tuhan tersebut. Program penginjilan dari rumah ke rumah, setelah dilaksanakannya "KKR-KKR" pun dilakukan di mana mereka bisa mendapat nomor kontak. Gereja baru akan ditahbiskan 
setelah terkumpul 12 jiwa yang dibaptis (ketentuan dalam lingkup gereja GBI).

Bergabungnya persekutuan-persekutuan, melebur dalam denominasi gereja dapat dikategorikan penanaman gereja. Afiliasi dan sistem "sister Church" juga sering dipakai dalam metode ini. Selain itu istilah "otonom" sering dipakai gerejagereja aliran Pentakosta.

Pelayanan holistik untuk orang-orang miskin, pembagian sembako, pengobatan gratis, pasar murah, PAUD, dan bimbingan belajar dapat juga menjadi media pembukaan gereja baru.

Studi Kasus: POAB, Pusat pelatihan Apostolik Bangsa Bangsa Batam adalah tempat pelatihan misiyang sedang berkembang. Dengan motto Recruit (Rekrut), Train (latih), Deploy (utus) dan Care (perhatikan), POAB adalah wadah yang sukses mengirim hambahamba Tuhan untuk menanam gereja baik di Indonesia maupun di bangsa-bangsa lain. ${ }^{15}$ Sebelum misionaris direkrut, "vision casting" adalah langkah pertama. Vision casting adalah pembagian visi, yang dikotbahkan, ditulis, ataupun diseminarkan di kalangan gereja, lembaga-lembaga kristiani, seminari, maupun sekolah-sekolah Alkitab. Vision casting ini diiringi dengan memberikan data-data lapangan, posisi daerah, dan kebutuhan. Biasanya tidak banyak orang yang merespons. Setiap angkatan hanya terdiri dari 9-21 orang. Pelatihan dilakukan setahun sekali dan maksimum 2 kali dalam setahun.

Adapun materi yang dibagikan 30\% berbicara soal penanaman gereja, pertumbuhan gereja, strategi, penginjilan dan kaum-kaum

15 POAB Batam, berdiri sejak 2005 untuk mengutus Hamba Tuhan Indonesia untuk menjadi penanam gereja baik di Indonesia maupun bangsa-bangsa. Data pada 2016, POAB telah mengirim missionaris ke-15 provinsi di Indonesia dan 14 negara. 
tertentu; 30\% berikutnya berbicara tentang survival, yaitu cara bertahan dalam situasi sulit ataupun mendesak, baik dalam keadaan diberkati atau tidak, baik di kota, desa maupun bangsa-bangsa. Geografi, cara membaca keadaannya dan melihat peta juga dipelajari. Dalam kelas ini juga diajarkan materi bertahan hidup, cerdik seperti ular dan tulus seperti merpati; 30\% lagi berbicara soal uang, yaitu cara mendatangkan penghasilan di ladang misi, business as mission, money mission dan model-model keuangan gereja; 10\% terakhir berbicara soal pastoral, pujian penyembahan, cara membaptis, dan Roh Kudus. ${ }^{16}$ Sebelum mahasiswa diterima, mereka harus membuat pernyataan di atas materai yang berbunyi bahwa mereka tidak takut mati, jika terjadi kejadian yang sampai merenggut nyawa mereka, mereka mengerti bahwa itu adalah tanggung jawab mereka sendiri.

Di POAB juga diadopsi tiga Filosofi, yaitu: 1. Filosofi sebagai tentara Mongolia, dimana setiap utusan misi yang diutus harus mempunyai prinsip seperti tentara Mongolia. Ketika tentara Mongolia mendarat di tempat sasaran, kapal harus dibakar terlebih dahulu supaya tentara itu tidak memikirkan pulang sebelum berhasil. Jadi, utusan misi tidak akan memikirkan pulang sebelum berhasil mendirikan jemaat, memenangkan jiwa atau membentuk kelompok sel. 2. Filosofi tentara Romawi. Tentara Romawi adalah tentara yang paling "lihai" dalam membaca peta daerah yang akan mereka serang dan duduki terlebih dahulu. Setelah daerah akan diduduki, mereka akan segera mengutus utusan berikutnya untuk mengambil peta berikutnya. Utusan misi POAB melihat tempat yang akan dituju, tidak terburu-buru langsung menanam gereja. Jika tidak memungkinkan, mereka harus melihat situasi dan memikirkan hal yang bisa mereka

16 POAB hanya menerima kandidat mahasiswa yang telah melayani minimal 3 tahun di gereja lokal. Adapun siswanya diharapkan merupakan lulusan SMU/sederajat sampai dengan S1 atau S2. 
lakukan, apakah membuka Bimbel, PAUD, minimarket, bengkel, dan lain-lain. Hal ini adalah "platform" bagi utusan misi untuk penjangkauan.

\section{Penanaman gereja melalui CPM/Gerakan Penanaman Gereja (Church Multiplication Through Church Planting Movements)}

Istilah CPM atau kegerakan penanaman gereja dipopulerkan oleh David Garisson dalam bukunya CPM. ${ }^{17}$ Definisi dari CPM/ GPG adalah Gereja yang menanam gereja yang menanam gereja lagi dalam waktu singkat. Saya merumuskan GPG yang umum yang merupakan kegerakan yang mempunyai hal-hal umum sebagai berikut:

\section{a. Empat hal Penting yang ada di pusat CPM/GPG}

1. Perubahan paradigma: Gereja harus mempunyai perubahan paradigma yang radikal bahwa penanaman gereja bisa dilakukan semua orang dalam tempo yang cepat dan tidak mengeluarkan biaya.

2. Disengaja: GPG harus dibiasakan atau disengaja.

3. Strategi: mengikuti hal yang dilakukan gereja mulamula dalam kegerakan.

4. Dapat berproduksi: Gereja melahirkan gereja, pemimpin melahirkan pemimpin.

Strategi ke empat ini menolong setiap orang percaya yang di-equip/dilatih untuk menjadi "Disciple maker" (pembuat

17 David Garrison, Church Planting Movement: How God is Reedeming Lost World (Midlothian, VA: WIGtake Resources, 2013), hal. 21-29. 
murid) di mana saja dan "tent-maker" (pembuat tenda) seperti rasul Paulus. Artinya pelayanannya tidak tergantung organisasi/ lembaga gereja.

\section{b. DNA dari kegerakan Penanaman gereja}

Sebuah gerakan penanaman gereja adalah suatu peningkatanpenambahan jiwa yang pesat DAN MULTLIPLIKATIF dari gereja yang menanam gereja lokal dalam satu kelompok orang atau satu segmen populasi. Menurut Garisson ${ }^{18}$ yang menjelaskan prinsip-prinsip dari gereja Baptis Amerika yang menemukan perkembangan GPG/CPM di seluruh dunia, ada sebelas elemen universal (umum) yang berlaku: 1. Doa, 2. Taburan Injil yang berlimpah, 3. Sengaja mengutus/menanam, 4. Otoritas yang alkitabiah, 5. Kepemimpinan Lokal, 6. Pemimpin dari kaum awam (yang tidak dibayar), 7. Bentuknya gereja sel atau rumah (10-30 anggota), 8. Gereja yang menanam gereja, 9 . Reproduksi yang cepat, 10. Tanda-tanda mujizat, 11. Gereja yang sehat (penyembahan, penjangkaun melalui misi dan penginjilan, pendidikan dan pemuridan, pelayanan, persekutuan).

Selain faktor universal, ada juga 10 (sepuluh) faktor khusus bagi suatu kegerakan: 1. Penyembahan dalam bahasa hati, 2 . Penjangkauan yang berfokus menjangkau keluarga besarnya, 3. Keterlibatan yang cepat dari orang-orang yang baru percaya, 4. Semangat dan tidak merasa takut, 5. Pengurbanan (bayar harga) untuk menjadi seorang percaya, 6. Kekosongan rohani dan disintegrasi sosial, 7. Pelatihan kerja untuk pelayanan, 8. Otoritas kepemimpinan yang didesentralisasi, 9. Sebagai orang

18 Garrison, Church Planting Movement: How God is Reedeming Lost World, hal. 171198. 
luar yang tetap "low-profile", 10. Misionaris yang siap bayar harga (peperangan rohani yang kuat).

Saya mengamati dan memerhatikan, gerakan penanaman gereja dapat terhenti ketika konsep gereja berupa gedung atau bangunan, memaksakan standar alkitabiah yang sangat tinggi untuk satu gereja, memaksa nilai-nilai atau value tertentu dalam satu komunitas, subsidi yang mengakibatkan ketergantungan, model gereja menjadi patokan, persyaratan menjadi pemimpin yang terlalu berat. Garrison menambah konsep gereja Kodok lawan gereja Cicak (dalam mencari mangsa lalat/nyamuk, kodok cenderung menunggu, tetapi cecak mengejar), gereja Kelinci versus gereja Gajah (kelinci yang setiap empat bulan bereproduksi dan dalam tujuh-delapan bulan sudah dewasa berbanding terbalik dengan gajah yang memerlukan 2 tahun untuk reproduksi dan puluhan tahun untuk menjadi dewasa). ${ }^{19}$

Sementara Rick Seward ${ }^{20}$ mengembangkan modifikasi CPM/GPG dengan beberapa modifikasi yang berhasil diterapkan dengan menambahkan hal-hal yang harus dilakukan: 1. Tahu bahwa Anda diurapi, 2. Pergi dalam tim minimal dua orang, 3. Segala sesuatu harus dibawa dalam doa, 4. Berdoa untuk pertemuan ilahi (divine appointment), 5. Demonstrasi kuasa Allah sangat dibutuhkan dan dipertontonkan kepada orang yang belum percaya (signs and wonder), 6. Bersedia untuk melayani, 7. Keintiman dengan Allah menjadi keharusan, 8. Dikuasai kerinduan untuk terus memberitakan Injil.

Perubahan paradigma sangat diperlukan dalam pengembangan CPM/GPG. Pelaksana harus mengerti betul

19 Makalah seminar Misiologi E21 Asia di SICC Sentul Jakarta pada 2014.

20 Rick Seward, Senior Pastor VFC Singapore. 
bahwa pengurapan diperlukan bukan untuk dalam gereja tetapi di luar sana, dengan tujuan untuk memberkati orang-orang yang belum percaya. Orang-orang yang baru percaya dapat dilatih untuk menjadi pemimpin di komunitas sel. Bahkan, pemimpin komsel bisa dilatih untuk menjadi penanam gereja. Definisi gereja harus jelas. Gereja adalah kumpulan orang percaya tempat dua atau tiga orang berkumpul dan sehati sehingga Tuhan hadir. Bukankah ini gereja? Bahkan, tubuh kita adalah bait Allah sehingga kehadiran utusan misi di satu daerah tertentu sudah boleh mewakili kehadiran Tuhan di tempat itu. Penanaman gereja harus bisa berkesinambungan. Artinya, menanam gereja dan menanam gereja lagi harus terjadi dan generasi kedua harus bisa membiayai dirinya. Bangunan bukanlah sesuatu yang utama.

\section{Faktor-faktor dan aturan main dari CPM/GPG supaya bisa berkembang}

Pelatihan singkat terhadap banyak orang untuk menjadi ketua-ketua kelompok sel atau ketua-ketua Cool (community of love/komunitas kasih) harus dilanjutkan dengan memilih pemimpin-pemimpin baru dari kelompok yang sudah dilatih untuk menolong menanam gereja. Pelatihan singkat juga diberikan untuk beberapa pemimpin agar menjadi penanam gereja. Di sini gembala-gembala diambil dari kaum awam dan misionaris hanya membantu menanam gereja awal saja yang selanjutnya tugasnya adalah membimbing gereja yang baru itu untuk membuka gereja yang baru lagi. Gembala-gembala yang baru segera dimuridkan. Tidak dianjurkan untuk membangun gereja-gereja yang besar karena sumber daya dan pendanaan akan tersedot, tetapi gereja-gereja kecil yang dimulai dari desa 
ke kota. Misionaris yang "fulltime" hanya membantu saja dan setelah waktunya tiba segera bergerak ke tempat lain.

Secara teologi, hal ini adalah doktrin biblika yang memercayai bahwa setiap orang percaya adalah "imam". Jadi, setiap pelayan jemaat ataupun jemaat bisa disiapkan untuk menjadi "gembala" di tempat ia ditempatkan, bisa di perusahan, di sekolah, di tempat kerja baik di kota maupun desa bahkan di bangsa-bangsa. Dalam hal ini, ukuran gereja dibatasi hanya maksimum 20 jemaat (Mat. 18:20: bahkan 2-3 orang percaya adalah gereja) agar mudah dimuridkan dan dimentor. Biasanya, gereja seperti ini disebut gereja rumah. Hal ini merupakan satusatunya gereja yang disebut dalam Perjanjian Baru (1 Kor. 14:26).

Model strategi ke empat banyak dilakukan di daerah yang mayoritasnya adalah Muslim, khususnya di Indonesia. Biasanya kegerakan ini juga di sebut "C" (Christ-centered Communities) ${ }^{21}$

Dalam pertemuan GCPN (Global church Planting Network) dan GACX (Global Alliance Church Multiplication) yang diadakan di pulau Batam pada 10-13 Mei 2016, dalam satu sesi pertemuan khusus "Church planters" Indonesia sehingga lahirlah ICPN (Indonesia Church Planting Network) yang diketuai F.Irwan Widjaja. ${ }^{22}$ Istilah ini khusus lahir untuk fokus penjangkauaan

21 John Travis (a pseudonym),"TheC1 to C6 Spectrum:A Practical Tool for Defining Six Types of "Christ-centered Communities" ("C") Found in the Muslim Context, “Evangelical Missions Quarterly 34/4 (Oktober, 1998): 407-408, described his contextualization spectrum and its utility.

22 F. Irwan Widjaja, ketua STT Real Batam, Board Executive GCPN dan Chairman Global Meeting di Batam 2016, praktisi misi lapangan dari tahun 1997, Mission Director BCS Singapore, Ketua POAB Batam, Gembala GBI My Home Tanjung Pinang, Rayon Misi Kepulauan Riau, staff ahli Misi Asia BPLN Asia Singapore, Chair Cluster Asia GCPN, Dosen Misi STT Real Batam dan STTHF Surabaya. 


\section{MISIOLOGI}

Indonesia dan penanaman gereja Regular dan Non regular. Gereja regular adalah gereja yang menggenapi visi denominasi (denominasional vision) dan Gereja non-regular adalah gereja sesuai dengan visi Tuhan Yesus, 2-3 orang berkumpul, Tuhan hadir. Gereja non-regular lebih dikhususkan pada penjangkauan saudara sepupu dengan CPM. Gereja regular dikenal dengan domba, tetapi gereja non-regular adalah "domba lain kandang".

Yohanes 10:16 berkata:

"ada lagi pada-Ku domba-domba lain, yang bukan dari kandang ini; domba-domba itu harus Kutuntun juga dan mereka akan mendengarkan suara-Ku dan mereka akan menjadi satu kawanan dengan satu gembala."

John Travis, menjelaskan dalam bukunya, bahwa semua kegerakan Christ-centered Community/Grup C1-C6, menyembah Yesus sebagai Tuhan adalah kunci utama dalam semua grup (c1-C6). Dalam tulisannya, Travis menemukan perbedaan setiap etnik, sejarah, tradisi, bahasa, budaya, dan dalam hal mereka memandang Tuhan (teologi). Dengan adanya keragaman tersebut, pendekatan-pendekatan diperlukan untuk memberitakan Injil. Tujuan dari pemahaman terhadap spektrum itu untuk membantu penanam gereja dan orang percaya berlatar belakang Muslim untuk memastikan jenis kelompok yang berpusat kepada Kristus seperti hal yang paling cocok menarik banyak orang dari kelompok sasaran dalam konteks tertentu. Ke-enam jenis kelompok itu, saat ini ditemukan di beberapa bagian dunia Muslim.

C1: Gereja-gereja/komunitas-komunitas orang percaya lokal, tetapi memakai bahasa/lagu-lagu dan tata cara bahasa asing (Traditional Church Using Outsider Language) 
Budaya dan kebiasaan Barat yang kental. Sering kali, gereja dianggap mengganggu tetangga dengan kebisingan-kebisingan. Biasanya pengikut $\mathrm{C} 1$ bangga disebut Kristen.

C2: Gereja-gereja lokal/komunitas-komunitas orang percaya dengan tradisi memakai bahasa sendiri (Traditional Church Using Insider Language)

Hampir sama dengan $\mathrm{C} 1$, tetapi bahasanya menggunakan bahasa lokal. Hanya saja, istilah-istilah (Vocabulary) Kristen tetap dipakai seperti haleluya, puji Tuhan, dll. Perbedaan budaya masih kental antara C2 dan orang lokal Muslim. Mereka tetap bangga jadi "Kristen" dan menyebut diri Kristen.

C3: Gereja-gereja lokal/komunitas-komunitas orang percaya yang dikonteksualisasi yang memakai bahasa sendiri (Contextualized Christ-centered Communities Using Insider Language and Religiously Neutral Insider Cultural Forms)

Kelompok C3 lebih netral, menggunakan bahasa, lagu-lagu, irama, dan nada lokal. Unsur-unsur Islam lebih kental (Islamic elements), tetapi diseleksi dan disesuaikan dengan budaya. Hal itu bertujuan untuk mengurangi "bantuan" gereja dengan cara mengontektualisasikan Alkitab yang masih diizinkan dalam budaya. Mayoritas jemaat berlatar-belakang Muslim dan mereka juga bangga disebut Kristen.

C4: Komunitas Christ-centered Kontekstual yang menggunakan bahasa sendiri dan secara Alkitabiah menggunakan bentuk dan budaya Islam yang dapat dipakai (Contextualized Christ-centered Communities Using Insider Language and Biblically Permissible Cultural and Islamic Forms) 
Sama dengan C3, tetapi secara alkitabiah mengizinkan bentuk dan kebiasaan Islam untuk dipakai dalam pelayanan ini (mis. doa dengan tangan diangkat terbuka, puasa Islam, menghindari makan babi dan minum alkohol, tidak memelihara anjing, menggunakan terminologi Arab dan pakaian Islami, dll). Tidak bersentuhan dengan bentuk $\mathrm{C} 1$ dan C2. Pertemuan tidak di gereja. Komunitas C4 hampir 100\% Islam. Lebih dikenal sebagai pengikut Isa ("followers of Isa the Messiah"or something similar).

C5: Mesianic Muslim, yang telah menerima Yesus sebagai Tuhan dan Juruselamat, atau yang lebih dikenal Insider Movement (Christ-centered Communities of "Messianic Muslims" Who Have Accepted Jesus as Lord and Savior)

Orang percaya tipe $\mathrm{C} 5$ tetap tinggal secara legal dalam komunitas Islam, sama seperti "Mesianic Jews Movement" di Israel. Mereka hidup memegang teologi "Islam" yang sama dengan isi Alkitab. Hal yang tidak sesuai tidak digunakan. Namun, ada juga yang menginterpretasikan isi yang disesuaikan dengan Injil. Penyembahan dan pujian dilakukan dalam bahasa dan gaya Islam. C5 bertemu secara reguler dan membagi iman mereka kepada sesama orang Muslim yang belum percaya. Ada juga seluruh kampung/desa yang menerima Kristus, bahkan ada tempat sembahyang/Mesjid Mesianik.

Pengikut C5 ini dilihat oleh pengikut Islam lainnya sebagai orang Muslim yang mengikuti Isa Almasih.

C6: Kelompok kecil yang percaya Yesus yang bergerak di "bawah tanah" (Small Christ-centered Communities of Secret) Underground Believers)

Kegerakan C6 sama seperti orang percaya yang dianiaya ("underground"). Oleh karena takut dianiaya, dikucilkan, diisolasi, 
takut akan Islam garis keras, pemerintah, takut dihukum maka tipe C6 ini menyembah Yesus secara diam-diam secara pribadi ataupun dalam kelompok yang lebih kecil. Pengikut $\mathrm{C} 6$ biasanya tidak mengumbar iman mereka dan biasanya diam-diam terhadap iman mereka. C6 dikenal sebagai pengikut Islam dan KTP mereka adalah Islam.

\section{Gereja/Komunitas yang dihasilkan (Reguler atau Non reguler)}

1. C1 menghasilkan gereja yang dasarnya sama dengan gereja induk pengutus (Missionaries establish a church that is basically identical to wherever they are from). Ibadah menggunakan bahasa yang digunakan gereja pengutus. Tidak ada kontak budaya lokal sama sekali. Contohnya adalah Gereja Indonesia di luar negeri.

2. C2, Sama dengan $\mathrm{C} 1$, tetapi ibadah menggunakan bahasa yang ada di rayon tersebut.

3. C3, Mereka mulai mengakomodir budaya lokal dan masuk dalam ibadah, pakaian, musik, dll. Namun, mereka menolak unsur-unsur Islam. Pertemuan diadakan dalam gedung gereja atau di tempat-tempat netral seperti Hotel, restoran, dan gedung-gedung umum lainnya. Mereka senang disebut Kristen. Sedikit kontekstualisasi.

4. C4, Sama dengan C3, tetapi banyak unsur unsur budaya Islam yang diakomodir. Menolak makan babi, gaya doa mirip orang Muslim tulen, pakaian hijab (Muslim dress), terminology menggunakan 
bahasa-bahasa Islam, dan menyebut diri pengikut Isa Almasih. Ibadah tidak di gereja. Namun, kelompok Muslim tidak menganggap mereka Muslim.

5. C5, Mempertahankan Identitas lokal mereka dalam komunitas Islam. Mereka menolak menerjemahkan atau menyesuaikan aktivitas atau kegiatan Islam dalam agenda Kristen ataupun membenturkan ajaran mereka dengan Alkitab. Mereka bukan pengunjung Mesjid yang reguler, tetapi mereka sangat aktif membagi iman mereka yang percaya Yesus kepada sesame orang Islam. Mereka menyebut diri mereka Muslim atau Muslim pengikut Isa Almasih. Mereka akan kelihatan sebagai orang Muslim yang taat baik dari luar maupun dalam bahkan kelihatan sedikit ortodoks.

6. C6, Kelompok ini memegang iman mereka dengan rahasia karena aniaya, penderitaan ataupun takut dianggap tidak legal. Ibadah dalam kelompok yang sangat kecil, tidak gampang bersaksi, bersaksi secara sangat hati-hati. Mereka 100\% kelihatan seperti orang berindentitas Muslim asli. 


\section{Pertumbuhan Gereja}

\section{Tujuan Pertumbuhan Gereja}

Tujuan pertumbuhan gereja dicetuskan oleh Donald McGavran ${ }^{1}$ dengan baik. Menurut McGavran, dalam rangka memenuhi panggilan misioner mereka, gereja harus menggunakan seluruh kemampuannya untuk menghasilkan angka pertumbuhan gereja. Perluasan kuantitatif adalah prioritas tertinggi dalam urusan gereja.

Gereja perlu mempertimbangkan secara serius pola-pola sosial budaya masyarakat setempat ketika mulai melayani di masyarakat tertentu supaya dapat meng-akarkan gereja lebih kuat di tanah sosial/budaya masyarakat tersebut. Seorang misionaris yang mulai bekerja di masyarakat tertentu

1 Donald McGavaran:Understanding Church Growth (Grand Rapids, MI:Eerdmans Publishing, 1990), hal. 133. 


\section{MISIOLOGI}

harus memilih keluarga-keluarga kunci yang memegang peran kepemimpinan. Hal itu karena semua keluarga dalam masyarakat homogen saling berhubungan/terikat satu dengan yang lain sehingga jika berhasil mempertobatkan keluarga kunci maka hal ini akan menghasilkan efek bola salju sehingga pada akhirnya semua keluarga besar akan merespons Injil.

Peter Wagner, berdasarkan buku karangan Donald McGavran The Bridges of God dan How Churches Grow menyatakan bahwa pertumbuhan Gereja berbicara tentang "semua yang terlibat dalam membawa pria dan wanita yang tidak memiliki hubungan pribadi dengan Yesus Kristus ke dalam persekutuan dengan Dia dan menjadi anggota gereja yang bertanggung jawab."

Kraus C. Norman 2 menemukan "pertumbuhan" dalam Perjanjian Baru paling sering digunakan untuk menunjukkan perkembangan menuju kedewasaan dalam tubuh Kristus (Ef. 4: 13-16). Namun, bisa juga diterapkan pada peningkatan jumlah murid dan pelipatgandaan gereja (Kis. 2:47). Kedua pertumbuhan ini penting untuk pelaksanaan misi yang efektif yang telah diberikan kepada gereja. Pertumbuhan tersebut mencakup kemenangan, pemeliharaan, dan peningkatan, termasuk pertumbuhan jumlah jemaat dan pelipatgandaan gereja.

Banyak ahli memberi penjelasan tentang pertumbuhan gereja, tetapi saya percaya bahwa ada faktor umum yang terkait dengan pertumbuhan Gereja. Pertumbuhan adalah bagian dari

2 Kraus C. Norman, "Introduction: Mission and Church Growth" in Mission, Evangelism and Growth, ed., by Kraus C.Norman (Scotdane, Pensylvania: Herald Press, 1980), hal. 30-31. 
sifat gereja. Penting dan perlu untuk mengamati berbagai jenis pertumbuhan Gereja. Pertumbuhan gereja dapat dilakukan dengan banyak cara atau seperti berikut ini:

1. Pertumbuhan Internal (Internal Growth): disebut juga sebagai Pertumbuhan Biologis. Hal ini berarti bahwa gereja tumbuh dalam dirinya sendiri. Menurut Wagner dalam bukunya Strategi untuk Pertumbuhan Gereja, "anak-anak keluarga Kristen tumbuh melalui program spesifik yang dirancang oleh Gereja dan anak-anak muda membawa orang muda lainnya kepada Kristus dan masuk ke dalam keanggotaan Gereja."

2. Pertumbuhan Numerik (Numeric Growth): bagian dari pertumbuhan biologis. Hal ini terjadi ketika seorang anak lahir dalam keluarga orang percaya dan dengan demikian secara otomatis menjadi anggota gereja tempat orangtua berada. ${ }^{4}$

3. Pertumbuhan transfer/perpindahan (Transfer growth). Hal ini terjadi ketika seorang percaya berpindah dari satu gereja ke gereja lainnya karena berbagai alasan, misalnya perubahan tempat tinggal, perubahan tempat kerja, dan lain-lain. ${ }^{5}$

4. Pertumbuhan Konversi (Conversion Growth): Hal ini terkait dengan membagikan Injil kepada mereka yang tidak percaya kepada Yesus Kristus sebagai

3 Peter C.Wagner, Strategy for Church Growth (Venture, CA: Regal Book, 1987), hal. 115.

4 Roy Pointer, How Do Churches Grow? (Basingstoke: Mashal Morgan \& Scott, 1984), hal. 105.

5 Ibid. 


\section{MISIOLOGI}

Tuhan dan Juruselamat. Ketika mereka membuat komitmen kepada Kristus, mereka dibawa ke gereja dan dibimbing untuk pertumbuhan. ${ }^{6}$

5. Pertumbuhan Restorasi (Restoration Growth). Inilah jenis pertumbuhan yang terjadi ketika orang-orang Kristen yang pernah meninggalkan Tuhan (murtad) kembali kepada Tuhan dan bergabung kembali dengan gereja tersebut.?

6. Pertumbuhan Bridging (penjembatanan). Hal ini berarti membangun atau menanam gereja baru dalam budayayang berbeda dengan gereja induk (pengutus). ${ }^{8}$

Dalam semua jenis pertumbuhan, ada faktor umum yang dilakukan dalam pertumbuhan, yaitu penginjilan. Model-model program penginjilan mempunyai andil dalam memenangkan jiwa jiwa tersebut. Dengan demikian, perlu diperhatikan bahwa penginjilan sangat penting dalam keseluruhan proses pertumbuhan gereja.

Dari berbagai model pertumbuhan gereja, hanya dua hal yang dapat disimpulkan sebagai berikut:

\section{A. Pertumbuhan Kualitatif}

Pertumbuhan kualitatif adalah pertumbuhan ke dalam, dimana setelah seseorang dimenangkan, tidak cukup hanya menjadi jemaat. Melalui pemuridan dan pelatihan, kehidupan rohaninya

\footnotetext{
6 Pointer, How Do Churches Grow?, hal. 105.

7 Ibid, hal. 106.

8 Michael Green, Evangelism Now and Then (Illionois: Intervarsity Press, 1997), hal. 13-14.
} 
meningkat. Ia tidak lagi hanya sebagai jemaat biasa, tetapi telah meningkat menjadi aktivis (pekerja magang sebelum ditahbiskan) dan terus belajar sampai pertumbuhan tingkat rohaninya mencapai level pekerja dan mulai melayani dan juga mulai menjangkau jiwa.

\section{B. Pertumbuhan Kuantitatif}

Hal ini adalah pertumbuhan jemaat yang meningkat melalui program-program penjangkauan. Dengan hal tersebut, jumlah jemaat bertambah dan mulai meningkat secara kuantitatif. Pertumbuhan juga bisa melalui kelahiran, perpindahan dari jemaat lain, bisa juga merupakan jemaat lama yang tidak aktif dan mulai bangkit dan mulai ke gereja lagi.

\section{Jemaat Pertama}

Jemaat mula-mula mempunyai sifat missioner dalam tugas memberitakan Injil yang sangat erat kaitannya dengan penjangkauan jiwa-jiwa. Sifat ini dapat diamati dalam kehidupan jemaat mula-mula. Melihat dari hal yang yang dilakukan oleh Gereja mula-mula dalam kaitannya dengan tugas kemisionerannya maka hal yang dilakukan oleh Gereja mula-mula tersebut dapat dijadikan sebagai acuan dalam menentukan strategi misi dan penjangkauan jiwa jiwa.

Bertekun dalam doa adalah kunci pertama seperti yang tertulis dalam Kisah Para Rasul 1:14, 23-25; 2:42; 4:23-31. Dalam ayat-ayat tersebut dikatakan bahwa mereka (Gereja mula-mula) bertekun dalam Doa. Menurut Tafsiran umum teolog dalam Kisah Para Rasul, dikatakan bahwa: 


\section{MISIOLOGI}

Ketujuh-belas pasal terakhir dalam Kisah Para Rasul terdapat beberapa referensi mengenai doa. Doa-doa orang kudus adalah dupa di atas altar emas, naik ke Allah Bapa, melalui pelayanan dari Imam Besar, Yesus Kristus (Why. 5:8; Mzm. 141:1,2; Ibr. 7:25). "Karena itu Ia sanggup juga menyelamatkan dengan sempurna semua orang yang oleh Dia datang kepada Allah. Sebab Ia hidup senantiasa untuk menjadi Pengatara mereka."

Sebuah gereja yang tidak berdoa adalah gereja yang tidak memiliki kuasa (Yud. 20). Kitab 1 Tesalonika 5:17; Gereja dilahirkan dalam doa. Doa dalam Roh. Rumah-Nya disebut "Rumah Doa" (Mat. 21:13).

Inilah cara Tuhan menambahkan jiwa-jiwa untuk gerejaNya. ${ }^{9}$

Doa $^{10}$ adalah sesuatu yang sangat penting dalam pelaksanaan tugas pemberitaan Injil. Melalui doa gereja dituntun dan mendapatkan perlindungan Tuhan dalam melaksanakan Amanat Agung tersebut.

Kuiper ${ }^{11}$ mengatakan bahwa dalam Kisah Para Rasul ada beberapa golongan orang Kristen. Hal ini sangat penting dipahami terutama dalam memahami dasar Alkitab untuk misi.

- Golongan pertama adalah jemaat mula-mula di Yerusalem. Tokoh utama di Jemaat Yerusalem adalah Petrus. Perhatian utama jemaat di Yerusalem adalah memberitakan Injil kepada orang-orang Yahudi.

9 Kisah Para Rasul (Karawaci: Harvest Internasional Teological Seminary), hal. $40-41$.

10 "Doa terus berkembang, hari-hari ini menara doa adalah kunci kegerakan misi," Pernyataan Pembuka Ps. Niko Njotorahardjo, GCPN-GACX Global Coference, Batam 10 Mei 2016.

11 Arie de Kuiper, Missiologia: Ilmu Pekabaran Injil (Jakarta: BPK Gunung Mulia, 1996), hal. 16. 
- Golongan kedua adalah jemaat Kristen Yahudi yang partikularistis. Mereka tetap terikat dengan Taurat; terbatas misinya kepada orang Yahudi. Mereka ini oleh Paulus disebut "saudara-saudara palsu...yang menyusup masuk, yaitu mereka yang menyelundup ke dalam untuk menghadang kebebasan yang kita miliki di dalam Kristus Yesus..." (Gal. 2:4).

- Golonganketiga adalahumat Kristen Yahudi peranakan Yunani. Mereka adalah orang-orang Yahudi diaspora yang telah masuk Kristen. Mereka disebut orang Yahudi berbahasa Yunani (Kis. 6:1) yang juga berpusat di Yerusalem. Akibat penganiayaan, mereka berserak ke daerah-daerah Yudea dan Samaria (Kis. 8:1), tempat mereka mulai mengabarkan Injil (Kis. 8:4), misalnya Filipus kepada orang Samaria (Kis. 8:5, 26). Bahkan seorang sida-sida dari Etiopia yang rupanya seorang proselit ditobatkan sampai dibaptis oleh pelayanan mereka (Kis. 8:26-40). Kegiatan misioner golongan ini tidak terbatas: Fenisia, Siprus, dan Antiokhia (Kis. 11:9) di mana Injil Tuhan dibawa sampai kepada orangorang Kafir (orang Yunani-Kis. 11:20).

- Golongan keempat adalah umat Kristen dari orangorang kafir bangsa-bangsa lain. Mereka dalah hasil dari Pelayanan PI Rasul Paulus dan kawan-kawannya (Kis. 13 dan 14).

\section{Yesus sebagai Model Pertumbuhan}

Implementasi penjangkauan jiwa-jiwa dapat dilihat dari model misi yang Yesus lakukan. Misi yang Yesus kerjakan adalah Misi 


\section{MISIOLOGI}

Kerajaan Allah. Misi Yesus adalah model misi Perjanjian Baru. Ia membentuk masyarakat untuk hidup di bawah kekuasaan Allah. Dalam Matius 4:13-17, dilaporkan bahwa Yesus memulai panggilan-Nya untuk mempertobatkan orang-orang kafir di Galilea, untuk menggenapi nubuatan dalam Yesaya 28:23 dan 9:2, bahwa "orang yang berjalan dalam kegelapan besar", yang di atas tadi disebut sebagai wilayahnya bangsa non-Yahudi, "telah melihat Terang yang besar" dari Yesus (Mat. 4:15-16).

Kitab Matius 8:5-13 menggambarkan seorang perwira kafir, yang telah datang untuk percaya kepada Yesus. Tentang dirinya Yesus mengatakan: "Aku belum menemukan iman yang sebesar ini, tidak, tidak di Israel" (ay. 10) dan menambahkan bahwa banyak orang dari ujung-ujung bumi yang jauh akan berpesta dengan para leluhur di surga, sementara banyak orang Yahudi ("anak-anak Kerajaan") akan diusir (ay. 12-13).

Dalam Matius 15:21-28, Yesus berada di wilayah nonYahudi lagi dan bertemu dengan seorang wanita Kanaan yang percaya, yang bersedia untuk merasa puas dengan remahremah bangsa Israel dan Mesias. Dalam perumpamaan tentang para pekerja di kebun anggur (Mat. 20:1-16), orang Yahudi tampaknya adalah yang terdahulu tetapi yang menjadi yang terkemudian dan bangsa-bangsa lain adalah yang terkemudian yang akhirnya menjadi yang terdahulu.

\section{a. Yesus memuridkan}

Mengawali pelayanan-Nya, Yesus memulai dengan memilih para murid-Nya (Mat. 4:18-22; Mrk. 1:16-20; Luk. 5:1-11). Memuridkan dan memberi keteladanan adalah gaya Yesus dalam 
bermisi. Dia mengajar, melatih, dan mempersiapkan para murid-Nya untuk pekerjaan yang besar. Dalam Matius 4:19 Yesus berkata kepada murid-murid-Nya, "Mari, ikutlah Aku, dan kamu akan Kujadikan penjala manusia." Konsen Yesus adalah mempersiapkan para murid untuk menjadi "penjala manusia," yaitu memenangkan jiwa-jiwa bagi kerajaan-Nya.

\section{b. Yesus mengutus murid-murid}

Dalam kitab Yohanes, pengutusan murid-murid ke dunia oleh Yesus dipahami sebagai kelanjutan pengutusan-Nya dari BapaNya dan pengiriman Roh Kudus oleh Bapa dan Yesus (Yoh. 14:26, 15:26, Luk. 24:49). Dalam Yohanes 20:21, Yesus mengatakan "Sama seperti Bapa mengutus Aku, Aku mengutus kamu." Contoh yang jelas adalah ketika Yesus dan Nikodemus bertemu, model dasar satu lawan satu dipraktikkan. Demikian pula dalam kisah Yesus dan perempuan Samaria. Dia mendekati orang lain, Dia menghindari menghakimi, tanpa arogansi-fakta dan kebenaran dalam kasih, Dia bertemu dengannya di tempat ia berada, sebagaimana ia adanya.

\section{c. Yesus fokus lintas etnis}

Penjelasan di atas menunjukkan bahwa Yesus sangat mengasihi jiwa-jiwa bukan berdasarkan latar belakang kesukuan, tetapi Dia mengasihi apa pun dan dari mana pun ia berasal. Yesus mengasihi semua bangsa (ethne). Dalam kitab Yohanes, Yesus juga menjangkau orang Non-Yahudi. Yohanes menunjukkan percakapan panjang Yesus dengan wanita Samaria. Percakapan ituberakhir dengan pengakuan dari seluruh kotaSamaria, "bahwa 


\section{MISIOLOGI}

ini memang Kristus, Juruselamat dunia" (4:42). Para penyembah yang benar harus menyembah Dia dalam roh dan kebenaran sehingga memberikan kemungkinan bagi bangsa-bangsa yang tinggal jauh dari Yerusalem sekarang bisa menyembah Tuhan sama seperti orang Yahudi. Yohanes menekankan dengan kuat bahwa Yesus bukan hanya Juruselamat orang Yahudi, tetapi untuk semua orang dan untuk memberitakan Injil kepada semua bangsa.

"Sama seperti Engkau telah mengutus Aku ke dalam dunia, demikian pula Aku telah mengutus mereka ke dalam dunia; dan Aku menguduskan diri-Ku bagi mereka, supaya mereka pun dikuduskan dalam kebenaran.Dan bukan untuk mereka ini saja Aku berdoa, tetapi juga untuk orang-orang, yang percaya kepada-Ku oleh pemberitaan mereka; supaya mereka semua menjadi satu, sama seperti Engkau, ya Bapa, di dalam Aku dan Aku di dalam Engkau, agar mereka juga di dalam Kita, supaya dunia percaya, bahwa Engkaulah yang telah mengutus Aku. Dan Aku telah memberikan kepada mereka kemuliaan, yang Engkau berikan kepada-Ku, supaya mereka menjadi satu, sama seperti Kita adalah satu:Aku di dalam mereka dan Engkau di dalam Aku supaya mereka sempurna menjadi satu, agar dunia tahu, bahwa Engkau yang telah mengutus Aku dan bahwa Engkau mengasihi mereka, sama seperti Engkau mengasihi Aku" (Yoh. 17:18-23).

\section{d. Yesus rela mengambil risiko}

Yesus mendemonstrasikan bahwa Dia rela mengambil risiko disalahpahami untuk kepentingan mendesak di sumur dengan wanita Samaria. Kitab Yohanes 4:1-38 mengatakan,

"'Makananku', kata Yesus, adalah melakukan kehendak Dia yang mengutus Aku dan menyelesaikan pekerjaan-Nya. Bukankah kamu mengatakan: Empat bulan lagi tibalah musim 
menuai? Tetapi Aku berkata kepadamu: Lihatlah sekelilingmu dan pandanglah ladang-ladang yang sudah menguning dan matang untuk dituai" (ay. 34-35).

Seperti perempuan Samaria, orang bersedia untuk mendengarkan Kabar Baik, tetapi ada kekurangan pekerja. Oleh karena itu, setiap orang percaya harus memenuhi pikirannya seperti Yesus atau banyak orang akan binasa dan masuk neraka. Waktunya sudah sangat singkat. Kitab 2 Petrus 3:9 mengatakan,

"Tuhan tidak lalai menepati janji-Nya, sekalipun ada orang yang menganggapnya sebagai kelalaian, tetapi Ia sabar terhadap kamu, karena Ia menghendaki supaya jangan ada yang binasa, melainkan supaya semua orang berbalik dan bertobat."

\section{e. Fokus Yesus memberitakan Kerajaan Allah}

Hal yang menjadi pusat pemberitaan Yesus adalah tentang Kerajaan Surga yang telah dekat (Mat. 4:17) dan oleh karena itu para pendengar sepatutnya bertobat. Ada perkembangan yang terjadi secara bertahap dalam Matius. Pertama-tama, berita itu dibawa khusus kepada segala domba-domba yang hilang dari umat Israel (Mat 10:5-7). Hal ini kembali diungkapkan Yesus dalam Matius 15:24 "Aku diutus hanya kepada domba-domba yang hilang dari umat Israel."

Meskipun demikian, Yesus juga tidak terikat dengan batas-batas kebangsaan, kebiasaan, dan keagamaan.

- Yesus datang menyelamatkan pemungut cukai dan orang-orang berdosa (Mat. 9:9-13).

- Yesus juga memberi perhatian kepada orang Samaria (Luk. 10; 17:11-19; Yoh. 4). 


\section{MISIOLOGI}

- Yesus juga menjelajah ke luar negeri, artinya ke wilayah-wilayah orang kafir (bangsa-bangsa bukan Yahudi) yaitu ke Tirus (Mrk. 7:24) dan ke Kaisarea Filipi (Mrk. 8:27).

Sebagai tambahan, Yesus juga memberi pernyataan tentang kedatangan bangsa-bangsa dalam Kerajaan Surga, setelah Dia bertemu dengan perwira Kapernaum yfang berasal dari bangsa kafir. Kitab Matius 8:11-12 mengatakan, "Aku berkata kepadamu: Banyak orang akan datang dari Timur dan Barat dan duduk makan bersama-sama dengan Abraham, Ishak dan Yakub di dalam Kerajaan Surga, sedangkan anak-anak Kerajaan itu akan dicampakkan ke dalam kegelapan yang paling gelap, di sanalah akan terdapat ratap dan kertak gigi."

\section{Pertumbuhan Kuantitatif Gereja Sekarang}

Pertumbuhan gereja masa kini hanya terfokus pada gereja kota atau urban yang hampir terjadi di seluruh pelosok tanah air, bahkan di luar negeri. Saya mengambil data yang dikeluarkan oleh Gordon Cornwell University yang melakukan penelitian dari 1970 sampai nanti 2020. Sejauh ini, ternyata kekristenan seluruh dunia hanya bertumbuh $0.1 \%$ (Lihat tabel di bawah, dari $33,2 \%$ naik menjadi 33,3\%). 


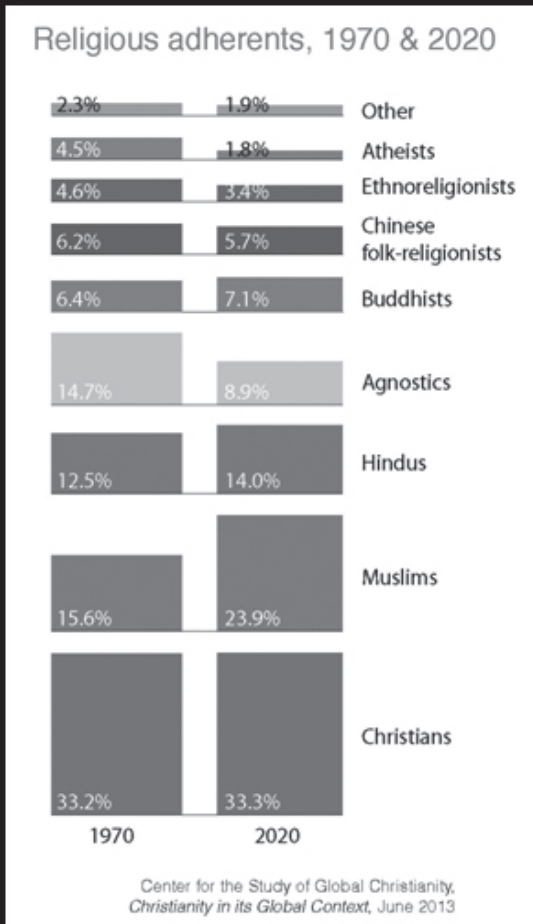

Tabel Perbandingan Pemeluk Agama Dunia 1970-2020 ${ }^{12}$

Saya mengamati, konsep gereja kota khususnya aliran Kharismatik, kenyamanan tempat ibadah dengan sound sistem yang baik merupakan tren khusus gereja-gereja kota. Saya juga mengamati dan memerhatikan-sebagaimana yang pernah diungkapkan sebelumnya bahwa gereja-gereja di kota besar umumnya secara serentak mempunyai kecenderungan penjangkauan melalui KKR kesembuhan ilahi, dengan berbagai

12 Christianity in Its Global Context, 1970-2020. Centre for the Study of Global Christianity, Gordon Cornwell, Theological Seminary, Juni 2013. 


\section{MISIOLOGI}

artis rohani sebagai penunjang, sementara kunjungan rumah sakit, membagi traktat, bagi-bagi sembako merupakan program selanjutnya. Program-program tersebut akan menarik orang yang belum ke gereja atau sudah lama tidak ke gereja akan datang ke gereja ("Unchurch"), tetapi juga akan menarik perpindahan dari jemaat yang tidak puas dari gereja tertentu.

Penggunaan media-media cetak dan elektronik dengan berbagai promosi di koran-koran, majalah-majalah, iklan di radio bahkan Televisi, situs web, dan ruang obrolan media sosial meningkat.

Pemakaian-pemakaian media tersebut biasanya lebih gencar dilaksanakan menjelang acara besar khusus yang akan dibuat gegap gempita. Jemaat dimobilisasi dan dimotivasi untuk membawa teman-teman ke pertemuan tersebut. Untuk memaksimalkan acara atau peristiwa khusus tersebut, programprogram di gereja dibuat megah bahkan pembicara dan orangorang dengan kesaksian-kesaksian tertentu turut dilibatkan untuk mempromosikan acara tersebut.

Pertumbuhan gereja/jemaat baru juga sering terjadi melalui perpecahan gereja. Akan menjadi hal yang fenomenal ketika gereja pecah dengan alasan tidak sevisi atau tidak sesuai lagi dan langsung di "cover" atau dinaungi oleh gereja yang berlainan denominasi atau sesama gereja dengan gembala senior yang berbeda. Tentunya fakta ini sangat tidak menyenangkan, tetapi menjadi bagian pertumbuhan gereja-gereja yang ada.

\section{Studi Kasus Batam}

Hasil survei penulis dalam menyusun disertasi secara umum di Kepulauan Riau dan secara khusus di Kota Batam, menunjukkan 
pertumbuhan orang Kristen yang signifikan sehingga menempatkan Kepulauan Riau sebagai provinsi pertumbuhan Kristen yang tertinggi di Indonesia. ${ }^{13}$

Akan tetapi di samping hal tersebut, fakta yang harus diketahui adalah, meskipun di Kepulauan Riau tercatat ada banyak gereja, tetapi hal itu hanya terkonsentrasi di Pulau Batam. Sebagaimana daftar yang diambil dari Kemenag Provinsi maupun kota menunjukkan gereja hanya terpusat di daerahdaerah kantong Kristen ${ }^{14}$ yang ada di Batam dengan total 437 gereja (per Februari 2015) terdiri dari 74 denominasi.

Setelah dilakukan kajian teoritis dan penelitian empiris sehingga didapati bahwa terdapat hubungan yang positif dan sangat signifikan antara Peran Pemimpin Gereja dan Strategi Misi Berdasarkan Kisah Para Rasul dengan Penjangkauan Jiwa-jiwa di Kota Batam. Hal ini ditunjukkan dengan adanya persamaan

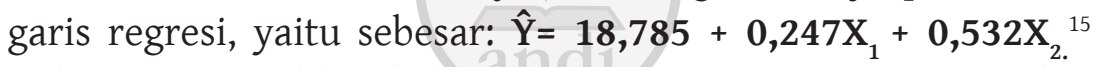
Hal ini menunjukkan bahwa jika Peran Pemimpin Gereja dan Strategi Misi Berdasarkan Kisah Para Rasul meningkat sehingga Penjangkauan Jiwa-jiwa di Kota Batam juga akan meningkat.

Dari hasil analisis regresi linear sederhana dan juga analisis regresi linear ganda yang telah dilakukan, diperoleh koefisienkorelasi (R) sebesar 0,718. Hal ini menunjukkan bahwa hubungan antara Peran Pemimpin Gereja dan Strategi Misi

13 Din Syamsuddin mengutip Leo Suryadinata menyatakan pertumbuhan umat kristiani sangat tinggi di Indonesia, perkiraan tahun 2035, Islam dan Kristen berbanding 50:50. Kontribusi terbesar pertumbuhan adalah Provinsi Kepulauan Riau tempat pertumbuhan pertahunnya adalah $8 \%$ lalu diikuti Sumatera Barat, Jawa Barat, dan D.I. Yogyakarta (7\%). Mi'raj Islamic News Agency/Detik-April 2015.

14 Data Kemenag Batam per bulan Februari 2015.

15 F. IrwanWidjaja, Disertasi Doktoral STT Real Batam, 2015, hal. 124-126. 


\section{MISIOLOGI}

Berdasarkan Kisah Para Rasul dengan Penjangkauan Jiwa-jiwa di Kota Batam adalah sebesar 71,80\%. Dengan demikian, hubungan Peran Pemimpin Gereja dan Strategi Misi Berdasarkan Kisah Para Rasul dengan Penjangkauan Jiwa-jiwa di Kota Batam adalah cukup kuat (subtansial) dan searah positif artinya bila Peran Pemimpin Gereja dan Strategi Misi ditingkatkan sehingga penjangkauan jiwa-jiwa di Kota Batam akan ikut naik.

Implikasi ini tentu menggembirakan bagi gereja-gereja di Batam. Adanya hubungan yang positif dan sangat signifikan antara Peran Pemimpin Gereja dan Strategi Misi (berdasarkan Kisah Para Rasul) dengan penjangkauan jiwa-jiwa di Kota Batam menunjukkan bahwa para pemimpin Kristen (gembala) dalam kepemimpinannya haruslah mengedepankan implementasi Amanat Agung dan menerapkan Strategi Misi sehingga membawa dampak kepada perubahan yang jauh lebih baik. Para pemimpin Gereja harus meningkatkan pelayanan yang berkaitan dengan terlaksananya Amanat Agung: penambahan jiwa-jiwa baru akan signifikan, pembukaan gereja baru di pulaupulau akan meningkat, pelatihan dan pengutusan tenaga misi akan meningkat, begitu juga dengan penambahan anggaran misi.

Data dari Gordon Cornwell University pada 2013 berikut ini menunjukkan prediksi pertumbuhan gereja di Asia meningkat 100\% dari tahun 1975 (4,5\%) menuju pada 2020 (9,2\%). Penulis percaya, Indonesia memberi kontribusi besar terhadap pertumbuhan tersebut. 
Tabel data pertumbuhan pemeluk pemeluk agama di Asia pada 1970 dan perkiraan pada 2020. ${ }^{16}$

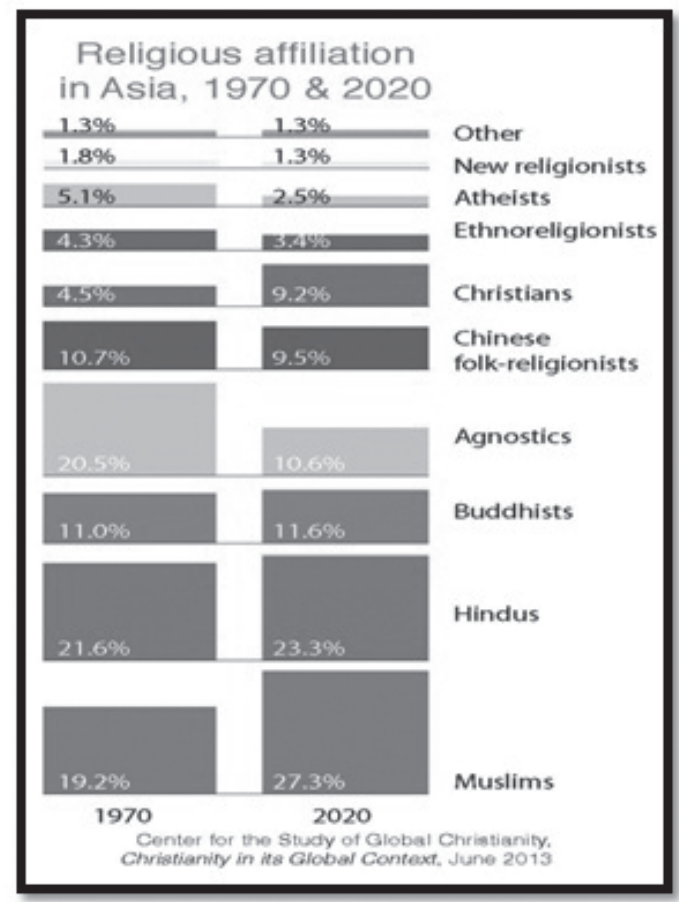

\section{Sarana Pertumbuhan Gereja}

Ada empat bidang yang dibuat dalam mendiskusikan cara melaksanakan misi, yaitu: Sarana untuk memberitakan Injil, sarana memenuhi tanggung jawab diakonia (pelayanan belaskasihan), sarana untuk membuka persekutuan/fellowship, dan sarana untuk pendidikan.

16 Christianity in Its Global Context, 1970-2020.Centre for the Study of Global Christianity, Gordon Cornwell, Theological Seminary, Juni 2013. 


\section{MISIOLOGI}

\section{Sarana memberitakan Injil17}

Perjanjian Baru muncul sebagai akibat dari pemberitaan Injil oleh jemaat mula-mula. Mengomunikasikan Injil adalah tanggung jawab yang tidak bisa dielakkan oleh siapa pun dan harus digenapi dengan berbagai upaya maksimal. Dalam Perjanjian Baru kita melihat ada berbagai cara untuk memberitakan Injil:

- Kerygma (Proklamasi/Pemberitaan) adalah bentuk yang digunakan oleh jemaat untuk memberitakan kepada mereka yang belum pernah mendengarkan Injil

- Didache (pengajaran) adalah cara memimpin orangorang yang sudah mendengar berita Injil dan berjalan dalam Kerajaan Allah

- Dialog adalah percakapan berkenaan topik dari kabar baik

- Surat dan Risalat diedarkan untuk memberitakan Injil dalam bentuk tulisan

Gereja pada masa kini menyadari bahwa berbagai cara dan sarana dalam misi perlu digunakan agar Injil dapat diberitakan kepada budaya-budaya yang berbeda dengan baik. Untuk itu, beberapa hal perlu dilakukan:

- Pendidikan Teologi yang menjadi sarana untuk memperlengkapi dan melatih orang per orang untuk menjalankan tugas penggembalaan dan misi.

17 F. Irwan Widjaja, Diktat STT Real Batam, Misiologi dan Pertumbuhan Gereja, 2014. 
- Penerjemahan Alkitab dan pendistribusiannya. Berkaitan dengan ini dibentuk lembaga-lembaga Alkitab di berbagai negara, menolong masyarakat buta huruf dan yang baru belajar baca tulis, menggunakan bantuan audio visual, meneruskan penerjemahan Alkitab ke berbagai bahasa dunia.

- Radio, Televisi, dan media cetak.

\section{Sarana untuk memenuhi tanggung jawab diakonia}

Kerajaan Allah tidak hanya berbicara mengenai kebutuhan rohani dan moral seseorang/masyarakat, tetapi juga harus menyentuh kebutuhan material, fisik, sosial, kebudayaan dan politis. Itulah sebabnya Yesus datang bukan hanya untuk memberitakan Firman, tetapi juga untuk melayani (diakonos). Dia membuat tanda-tanda Kerajaan Allah menjadi kelihatan bagi manusia: orang buta melihat, orang lumpuh berjalan, orang kusta disembuhkan, orang yang lapar mendapat makanan untuk dimakan, dan orang yang kesepian mengetahui bahwa ia tidak sendiri lagi. Begitu juga dalam jemaat Perjanjian Baru, sejak awal berdirinya, gereja sudah memulai pelayanan diakonia. Dalam 2 Korintus 9 misalnya, kita bisa melihat contoh cara gereja membantu gereja lainnya. Hal itu menjadi bukti bahwa gereja sejak awalnya sudah sadar akan panggilan diakonianya.

Verkuyl memberikan beberapa bentuk dari pelayanan diakonia yang telah dilaksanakan oleh gereja. Bentuk-bentuk pelayanan diakonia tersebut adalah:

- Pendidikan. Bentuk yang paling mudah dilihat adalah berdirinya sekolah-sekolah Kristen oleh para misionaris dan juga oleh gereja. 


\section{MISIOLOGI}

- Pelayanan sosial dan rumah sakit. Misalnya mendirikan rumah sakit, misi medis ke daerah-daerah yang terlibat peperangan, panti rehabilitasi, dsb.

- Pelayanan diakonia lainnya. Misalnya pertolongan terhadap korban bencana alam, pelayanan terhadap para nara pidana, pertolongan kepada yatim piatu, dan orang cacat.

\section{Pengalaman Saya}

Gereja pada masa kini menyadari bahwa berbagai cara dan sarana dalam misi perlu digunakan agar Injil dapat diberitakan kepada budaya yang berbeda dengan baik.

Awal penempatan dan pengembangan misi lokal dilakukan dengan menjawab kebutuhan didaskalia, diakonia, dan koinonia.

Pada awal Oktober 2004, melalui mentoring dari gereja Induk Singapura ${ }^{18}$ pengutusan dimulai untuk ke Tanjung Pinang. Hal ini adalah kota tua yang menjadi ibukota Provinsi Kepulauan Riau ${ }^{19}$ yang kondisi jemaat gereja yang ada saat itu hanya berkisar 50-60 orang dan ada pulau-pulau di sekitarnya

18 Pdt. Djohan handojo, Senior Pastor Bethany Church Singapura dan Bethel World Mission Chairman mengutus hamba Tuhan F. Irwan Widjaja ke Tanjung Pinang untuk menggembalakan GBI Rayon 20, yang kemudian diganti menjadi GBI Rayon Misi My HOME (House of Mission and Evangelism) Tanjung Pinang, Pulau Bintan, Provinsi Kepulauan Riau.

19 Provinsi Kepulauan Riau yang terbentuk berdasarkan Undang-undang Nomor 25 tahun 2002 merupakan provinsi ke-32 di Indonesia yang diresmikan Presiden Republik Indonesia Ibu Megawati Sukarnoputri pada 24 September 2002. 
yang juga perlu dijangkau. Untuk itu, menara doa adalah kunci untuk visi penjangkauan. Melalui menara doa, visi diberikan, yaitu dari Matius 9:35;

"Demikianlah Yesus berkeliling ke semua kota dan desa; Ia mengajar dalam rumah-rumah ibadat dan memberitakan Injil Kerajaan Surga serta melenyapkan segala penyakit dan kelemahan."

Dua hal yang perlu diperhatikan dari ayat tersebut:

- Yesus berkeliling dari desa dan kota.

- Memberitakan kabar baik, mengajar, dan menyembuhkan.

- Kabar baik diberitakan melalui firman secara langsung, kabar baik diberitakan melalui pendidikan. Dari visi ini, lahir sekolah-sekolah dari tingkat PAUD sampai SMK, bahkan training centre, Bimbel, sekolah tinggi, yang terus akan ditingkatkan sampai kepada Universitas.

- Kabar baik juga diberitakan lewat media, baik media pendengaran, penglihatan, maupun media cetak. $^{20}$ Yesus menyembuhkan, baik secara fisik, mental dan kejiwaan juga menyembuhkan secara ekonomi, program-program sosial, pasar murah, pengobatan gratis, dan pembangunan rumah sehat (sedang persiapan, setingkat rumah sakit tipe D) dilakukan untuk penjangkauan.

20 Radio, TV lokal, dan surat kabar daring yang dimiliki gereja lokal. 


\section{Sarana memberitakan Injil melalui persekutuan (koinonia)}

Persekutuan adalah sarana unggul untuk membawa seseorang kepada Yesus dan kepada komunitas Mesianik yang disebut Ekklesia (gereja). Berdasarkan hal tersbeut, kita tentunya perlu mendorong cara-cara baru untuk membuat persekutuan orang percaya. Persekutuan-persekutuan dapat dilakukan di mana pun dan dalam bidang apa saja sesuai dengan profesi; bisa persekutuan karyawan, persekutuan kantor, bisnismen, pelajar, profesi guru, dokter, dan lain lain. Persekutuan yang sering menjadi tulang punggung gereja adalah persekutuan keluarga atau rumah tangga. Bahkan kelompok sel gereja lokal, yang sering bertemu satu minggu satu kali adalah sarana persekutuan yang efektif untuk membawa jiwa baru.

\section{Sarana memberitakan Injil melalui pendidikan (didaskalia)}

Pendidikan dalam dunia kekristenan bisa dilihat dari dua sudut yang berbeda. Hal yang pertama dilihat dari kacamata gereja sebagai alat mendidik, sebagaimana kerinduan Tuhan seperti tergambar dalam Titus 2:11-12:

"Karena kasih karunia Allah yang menyelamatkan semua manusia sudah nyata. Ia mendidik kita supaya kita meninggalkan kefasikan dan keinginan-keinginan duniawi dan supaya kita hidup bijaksana, adil dan beribadah di dalam dunia sekarang ini."

Proses mendidik ini dilakukan Allah kepada gereja-Nya, terutama kepada para pelayan-Nya dan untuk selanjutnya diteruskan kepada orang lain (2 Tim. 2:2) 
Apa yang telah engkau dengar dari padaku di depan banyak saksi, percayakanlah itu kepada orang-orang yang dapat dipercayai, yang juga cakap mengajar orang lain.

Darisisiyanglain dalam sejarah pekabaran Injil, pendidikan adalah usaha mencerdaskan kehidupan dan merupakan pintu masuk mendekatkan anugerah Allah kepada anak didik dan keluarganya. Pendidikan merupakan unsur penting dalam masyarakat majemuk. Pendidikan dalam arti mengajar cerdas dapat diterima oleh semua pihak dan golongan.

Alkitab menyaksikan bahwa mendidik merupakan aktivitas yang tidak terpisahkan dari pelayanan Tuhan Yesus dan Dia tampil sebagai guru di panggung sejarah. Pendidikan merupakan bagian integral dari perintah agung Tuhan Yesus. Oleh karena itu, gereja yang sungguh mengasihi Tuhan Yesus dan yang tetap setia melaksanakan amanat agung adalah gereja yang tidak mengabaikan pendidikan dan tetap melaksanakannya secara konsisten. Gereja di segala abad bertanggung jawab untuk mencerdaskan umat manusia melalui pendidikan.

Sejak awal kehadiran gereja di Indonesia, pendidikan merupakan salah satu bidang pelayanan yang dianggap utama yang bertolak dari nilai-nilai Injil Kerajaan Allah yang menyelamatkan, yang membebaskan manusia dan dunia ini dari genggaman dosa yang terwujud dalam berbagai bentuk. Dengan demikian, untuk menyikapi hal tersebut, gereja harus mengembangkan sistem dan metode pendidikan yang sesuai dengan tuntutan Injil dan masyarakat. Praktisnya, gereja bisa melaksanakan pendidikan dalam bentuk formal sesuai undang undang pendidikan, bisa juga bentuk non-formal berupa kursus kursus ataupun informal seperti bimbingan belajar, rumah singgah, dan lain-lain. 


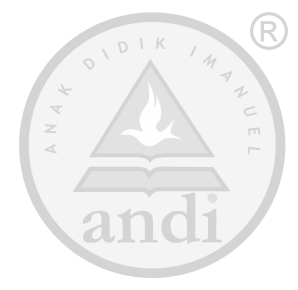




\section{Misi Holistik}

$\bigvee_{\text {mandat yang dipercaya dalam penjangkauan: }}^{\text {isi yang holistik adalah misi }{ }_{\text {mang }} \text { menjalankan dua }}$

\section{A. Dua mandat}

\section{Mandat Budaya}

Mandat budaya menunjuk kepada tanggung jawab sosial yang dapat ditelusuri ke belakang ke taman Eden. Setelah Allah menciptakan Adam dan Hawa, Dia berfirman kepada mereka, "beranak cuculah dan bertambah banyak; penuhilah bumi dan taklukkanlah itu, berkuasalah atas ikan-ikan di laut dan burungburung di udara dan atas segala binatang yang merayap di bumi" (Kej. 1:28). Sebagai manusia yang diciptakan segambar dan serupa dengan Allah, kita bertanggungjawab untuk menjaga dan memelihara kesejahteraan ciptaan Allah.

Dalam Perjanjian Baru kita diajarkan supaya mengasihi sesama seperti diri kita sendiri (Mat. 22:39). Pengertian sesama, 


\section{MISIOLOGI}

sebagaimana terungkap dalam perumpaan orang Samaria yang baik hati, tidak terbatas hanya pada orang-orang sesuku atau sekelompok budaya atau pun seagama, melainkan semua orang. Berbuat baik kepada orang lain, baik itu kepada seseorang ataupun kepada masyarakat secara keseluruhan, adalah kewajiban yang sesuai dengan saran Alkitab dan merupakan mandat budaya yang diberikan Allah kepada kita.

\section{Mandat Penginjilan}

Mandat Penginjilan juga berawal dari Taman Eden. Pada awalnya, setiap kali Allah pergi ke Taman Eden, Adam dan Hawa telah menunggu kedatangan-Nya, dan mereka mempunyai persekutuan dengan Allah. Namun, dosa masuk dan begitu Allah pergi ke taman itu, Dia tidak lagi menemukan Adam dan Hawa. Persekutuan itu telah rusak. Manusia telah terpisah dari Allah. Sifat Allah nampak jelas dalam peristiwa itu dari perkataan-Nya, “Adam, dimanakah engkau?" (Kej 3:9) Dia segera mencari Adam.

Mandat Penginjilan melibatkan pencarian dan penemuan orang-orang yang terhilang, terasing dari Allah oleh dosa. Kitab Roma 10 mengatakan bahwa barang siapa berseru kepada nama Tuhan akan diselamatkan. Namun, mereka tidak dapat berseru kepada-Nya jika mereka tidak percaya kepada-Nya dan mereka tidak dapat percaya kepada-Nya jika mereka tidak pernah mendengar tentang Dia. Mereka tidak dapat mendengar tentang Dia jika tidak ada orang yang memberitakan-Nya. "Betapa indahnya kedatangan mereka yang membawa kabar baik!" (Rm. 10:13-15). Membawa berita Injil yang dapat memindahkan orang dari kegelapan kepada terang berarti kita telah melaksanakan mandat Penginjlan. 
Sehubungan dengan kedua mandat tersebut, perdebatan muncul dan menyebabkan ada 5 posisi dalam misi:

- Misi adalah berhubungan dengan mandat budaya. Kita tidak perlu memengaruhi orang lain agar mereka menganut kepercayaan yang sama dengan kita.

- Mandat budaya lebih diprioritaskan daripada mandat penginjilan.

- Kedua mandat itu harus mendapat perhatian yang sama dan yang satu tidak boleh dutamakan dari yang lain.

- Mandat Penginjilan harus didahulukan dari pada mandat budaya.

- Misi adalah identik dengan mandat penginjilan.

Menurut Wagner, ${ }^{1}$ posisi yang keempatlah yang paling penting. Hal ini disebabkan karena jika Adam dan Hawa makan buah pohon itu, mereka akan mati (Kej. 2:17). Ternyata mereka tidak langsung rebah mati seperti pada Ananias dan Safira. Jadi, mereka mati dalam arti apa? Menurut Wagner, mereka mati dalam tiga pengertian: mati secara rohani, mati secara jasmani, dan mati secara materi atau secara sosial.

1. Kematian secara materi atau secara sosial. Di Taman Eden, Adam dan Hawa tidak perlu bersusah payah memenuhi kebutuhan materi mereka. Namun, setelah mereka jatuh dalam dosa, mereka diusir dari Taman Eden dan hanya dengan berpeluh mereka

1 Peter C. Wagner, Strategi Perkembangan Gereja (Malang: Gandum Mas,2003). hal. 188. 
akan mendapatkan makanan mereka. Inilah titik awal segala masalah kehidupan manusia: kemiskinan, peperangan, penindasan, diskriminasi, perbudakan, ketidakadilan sosial, dan kelaparan. Lalu apa yang harus kita lakukan sebagai orang Kristen? Mematuhi mandat budaya dengan mengasihi sesama seperti diri sendiri. Kita ikuti teladan Yesus yang berkata: "Roh Tuhan ada pada-Ku, oleh sebab Ia telah mengurapi Aku, untuk menyampaikan kabar baik kepada orang-orang miskin" (Luk. 4:18).

2. Kematian secara jasmani. Sebelum jatuh dalam dosa, sakit penyakit dan kematian tidak terdapat di Taman Eden. Walaupun Adam dan Hawa tidak langsung mati pada saat berbuat dosa, tetapi akibat dosa itu mereka menjadi makhluk yang fana. Kematian jasmani menjadi sesuatu yang tidak terelakkan dan akhirnya keduanya meninggal. Demikianlah, saat ini kita masih hidup di dunia yang penuh dengan sakit-penyakit, kesengsaraan, dan kematian. Sebagai orang Kristen, kita harus mematuhi mandat budaya itu.

3. Kematian secara rohani. Kematian rohani berarti putusnya hubungan dengan Allah. Hal ini adalah kematian yang paling serius di antara ketiga kematian tersebut. Masalah-masalah materi dan sosial sifatnya hanya sementara, begitu juga pemecahan masalah tersebut tidak bersifat permanen. Sedangkan kematian rohani tidak bersifat sementara, tetapi abadi. Jika seorang sesat dilahirkan kembali dan mengikuti Yesus serta membina kembali persekutuan dengan 
Allah Bapa, hal itu tidak akan pernah berakhir. Barangsiapa percaya kepada Yesus tidak binasa, melainkan beroleh hidup yang kekal (Yoh. 3:16). Dengan membantu terwujudnya hal-hal di atas berarti kita memenuhi mandat penginjilan. Pada prinsipnya, untuk memenuhi mandat penginjilan inilah Yesus datang ke dunia dan rela mati; "Sebab Anak Manusia datang untuk mencari dan menyelamatkan yang hilang" (Luk. 19:10).

\section{B. Penginjilan}

Dalam kaitannya dengan tugas pemberitaan Injil, penginjilan merupakan hal utama yang dilakukan oleh Gereja mula-mula. Bahkan pada saat gereja harus terserak karena aniaya (Kis. 8), mereka menjadi jemaat misioner. Menurut Tafsiran Kisah Para Rasul, dikatakan:

Penganiayaan yang hebat mulai dialami gereja di Yerusalem. Iblis telah mengadakan upaya perlawanan secara agamawi dan politis dari luar. Ia telah mengadakan upaya penyelewengan rohani dari dalam dan di sini kita melihat si musuh sedang berusaha memecah-mecahkan hal yang tidak bisa ia hancurkan atau ia selewengkan.

Allah mengizinkan penganiayaan datang untuk menantang gereja sehingga orang-orang Kristen mau meninggalkan Yerusalem dan menggenapi amanat agung karena semua upaya penginjilan dipusatkan di Yerusalem. Allah menginginkan Firman Injil masuk dalam semua bagian dunia, kepada setiap mahluk. 
Penganiayaan tidak menghancurkan Firman, melainkan hanya menyebarkannya. Firman itu disebarluaskan ke daerah yang lebih luas, bahkan dunia. ${ }^{2}$

Gereja telah mengalami berbagai ujian yang sangat berat, tetapi semangat penginjilan untuk memberitakan dan menyaksikan Kristus kepada dunia tidak pernah padam. Oleh karena kesetiaan pemberita-pemberita Injil maka gereja masih tetap ada sampai sekarang dan akan selalu ada sampai Kristus datang kembali. Ada dua kata Yunani yang berkaitan dengan tugas pemberitaan Injil pada zaman Gereja mula-mula, yaitu:

- Kerusso, yaitu menyatakan sebagai suatu pengumuman (Kis. 8:5), kata ini oleh LAI, Alkitab Terjemahan Baru, diterjemahkan "memberitakan."

- Euanggelizo, yaitu menyampaikan Kabar Baik (Kis. $8: 4,12,25,35,40)$. Kata penginjil berasal dari kata ini. Ayat-ayat ini sering diterjemahkan oleh LAI, Alkitab Terjemahan Baru, dengan kata "memberitakan Injil." Namun menurut Tafsiran Kisah Para Rasul dari Harvest Internasional Teological Seminary, ayatayat tersebut juga sering diterjemahkan menjadi "berkhotbah." Berkhotbah berarti menyatakan sebagai pengumuman, menyampaikan Kabar Baik sehingga dinamakan Penginjilan. ${ }^{3}$ Melihat pernyataan tersebut maka penginjilan dapat dilakukan melalui berkhotbah.

\footnotetext{
2 Kisah Para Rasul (Karawaci: Harvest Internasional Teological Seminary), hal. 40-41.

3 Ibid., hal. 78.
} 
Para jemaat mula-mula adalah jemaat yang misioner, tempat jemaat secara pribadi maupun kelompok sangat bersemangat dalam memberitakan Injil. Hal ini dibuktikan dengan terjadinya penambahan jumlah murid seperti yang dikatakan R. Dixon:

Hasil dari pemberitaan Injil itu, ialah "jumlah murid makin bertambah." Jika kita rajin memberitakan Injil, gereja Tuhan akan berkembang. Jika kita malas atau takut ataupun dengan alasan lain lagi, kita tidak bersaksi dan menginjili orang-orang baru, tentu gereja tidak akan bertambah. ${ }^{4}$

\section{Klasifikasi Penginjilan: E-1, E-2, dan E-3}

Penginjilan dapat dikasifikasikan sebagai berikut:

- E-0 atau penginjilan nol adalah proses membimbing orang-orang yang telah menjadi anggota gereja kepada penyerahan hidup kepada Yesus Kristus. Di sini yang dihasilkan adalah meningkatnya kualitas, bukan kuantitas.

- E-1 atau penginjilan satu adalah membawa orang-orang dari kelompok budaya yang sama kepada Kristus. Untuk melakukan hal ini, tidak diperlukan bahasa asing atau penyesuaikan diri dengan makanan yang asing ataupun mengadopsi adat istiadat yang baru.

4 R. Dixon, Tafsiran Kisah Para Rasul, Cet. ke-4 (Malang: Gandum Mas, 1997), hal. 38. 
- E-2 atau penginjilan dua adalah penginjilan orang-orang dengan budaya yang sama, tetapi berjauhan dengan jarak dan tempat. Contohnya adalah orang Indonesia melayani orang Indonesia di Malaysia.

- E-3 atau penginjilan tiga menunjuk kepada penginjilan antarbudaya. Untuk melakukan hal ini, orang yang harus dilayani adalah orang-orang dari budaya yang berbeda dengan budaya kita. Dalam E-3, budaya orangorang yang diinjili berbeda cukup jauh dengan budaya kita. Misalnya, adalah orang Indonesia menginjili orang-orang Jepang.

\section{Jendela $10 / 40$}

Jendela 10/40 atau yang sering dikenal dengan Ten Forty Window adalah wilayah dunia yang terletak di antara 10' LU dan 40' LU yang meliputi Afrika Utara, Timur Tengah, dan Asia. Jendela ini memperlihatkan bagian dunia dengan kebutuhan fisik dan spiritual terbesar, sebagian besar adalah "unreached people" yang belum terjangkau atau terabaikan dan sebagian besar pemerintahannya menentang agama Kristen. ${ }^{5}$

Menurut Joshua Project, jendela 10/40 sering disebut sebagai "the resistant belt" (sabuk penolakan) dan meliputi Dunia Muslim, Hindu, dan Buddha. Pembaruan konsep jendela 10/40 kemudian merangkum juga negara-negara dekat dengan wilayah 10/40 seperti Indonesia. Diperkirakan sebanyak 4,45 miliar orang tinggal di wilayah 10/40 yang diperbarui dengan sekitar 8,807 kelompok masyarakat.

5 Operation World Handbook 2010. 


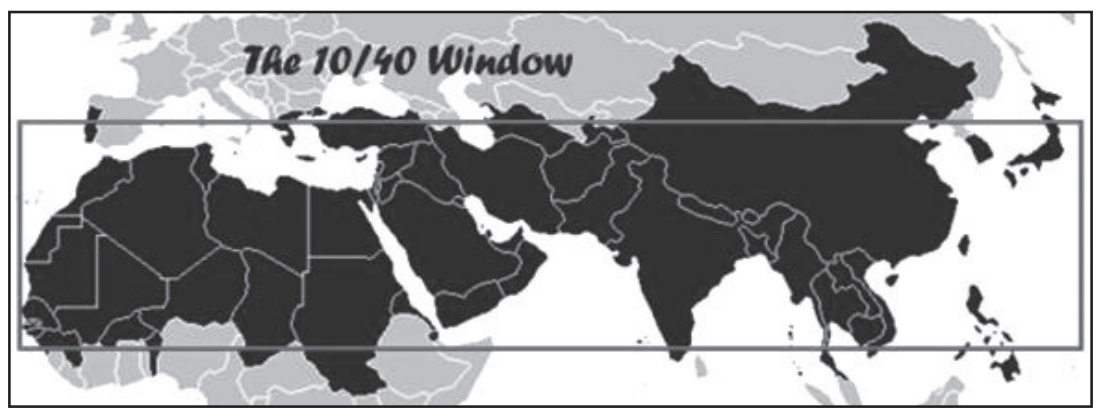

Ada beberapa hal penting yang dipertimbangkan dari jendela 10/40:

- Hubungannya dengan dunia Alkitab dan Sejarah. Alkitab mulai dengan kisah Adam dan Hawa yang ditempatkan Tuhan di jantung jendela 10/40. Kejatuhan manusia dalam dosa dan menara Babel terjadi di jantung jendela 10/40.

- Dalamnya terdapat negara-negara yang paling sedikit dijangkau oleh Injil. Mereka memiliki pengetahuan minimal tentang Injil, tetapi tidak punya kesempatan yang wajar/sah untuk merespons Injil.

- Unreached People Groups (UPG) dan kota-kota yang belum terjangkau. Diperkirakan 2,72 miliar penduduk yang hidup dalam sekitar 5.905 UPG berada di wilayah jendela 10/40. Selain itu, jendela 10/40 mencakup sebagian besar dari kota-kota besar di dunia yang sangat kurang terjangkau Injil. Lima puluh kota besar rangking atas yang kurang terjangkau Injil di dunia berada di jendela 10/40. Hal ini menunjukkan perlunya memberi prioritas khusus bagi penginjilan di jendela 10/40. 
- Dominasi halangan dari 3 agama. Jendela 10/40 berisi 4 blok dominasi agama: Islam, Hindu, Buddha, dan Tak beragama (Non-religious).

- Jumlah terbesar dari orang miskin. Sebagian besar orang miskin dunia tinggal di jendela 10/40. Yang termiskin dari orang miskin sedunia, yang jumlahnya diperkirakan lebih dari delapan dari sepuluh orang tinggal di wilayah ini. Ada istilah "Yang miskin adalah yang terhilang, yang terhilang adalah yang miskin" sebagaimana mayoritas orang yang belum dijangkau hidup dalam negara-negara termiskin dunia. Ada tumpang tindih yang luar biasa antara kemiskinan dengan kurang terinjilinya mereka.

- Kubu-kubu dari Setan dalam jendela 10/40. Jendela 10/40 tidak hanya tempat miliaran penduduk hidup menderita dalam kemiskinan dan penyakit. Mereka juga adalah contoh dari hal yang dikatakan dalam 2 Korintus 4:4 "mata mereka telah dibutakan oleh ilah zaman ini..."

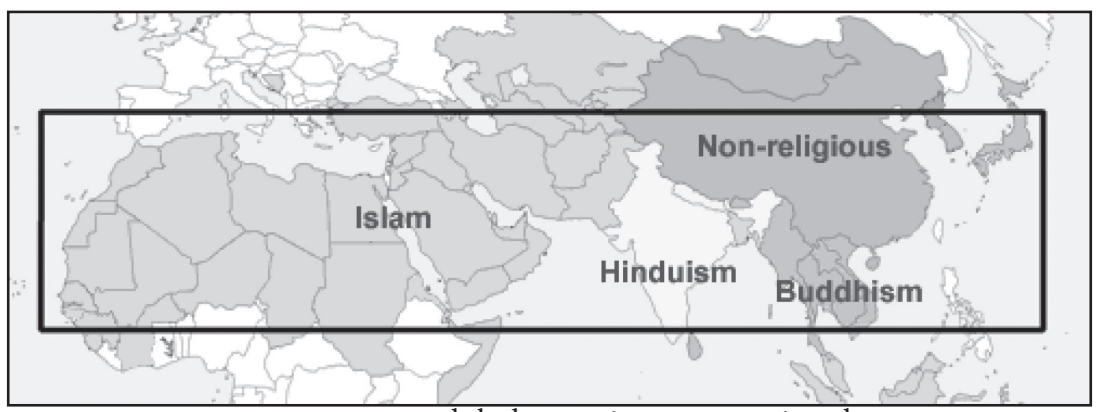

Map Source: Global Mapping International

Selain penjangkauan berdasarkan Ethne (suku bangsa), sebagaimana tercatat dalam Filipi 2:10-11, 
"supaya dalam nama Yesus bertekuk lutut segala yang ada di langit dan yang ada di atas bumi dan yang ada di bawah bumi, dan segala lidah mengaku: 'Yesus Kristus adalah Tuhan,' bagi kemuliaan Allah, Bapa!"

para pakar dan praktisi lapangan, orang misi dan lembagalembaga juga memikirkan agar setiap kaum yang ditunjukkan melalui lidah dan bahasa yang berbeda terwakili, sebagaimana diungkapkan dalam Wahyu 7:9:

"Kemudian dari pada itu aku melihat: sesungguhnya, suatu kumpulan besar orang banyak yang tidak dapat terhitung banyaknya, dari segala bangsa dan suku dan kaum dan bahasa, berdiri di hadapan takhta dan di hadapan Anak Domba, memakai jubah putih dan memegang daun-daun palem di tangan mereka."

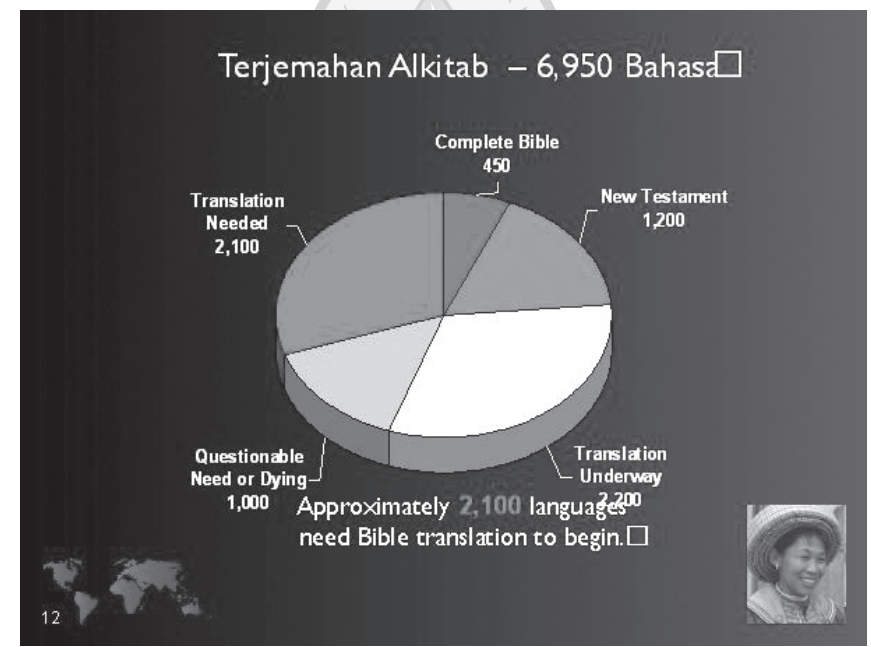

Data dari Joshua Project 2010 tentang Penterjemahan Alkitab sampai saat ini. Perjalanan panjang masih dibutuhkan untuk penterjemahan Alkitab dalam bahasa ethne/suku. 


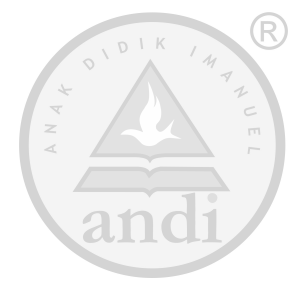




\section{Keuangan Misi}

B icara soal misi, pasti ada banyak hal yang menyangkut

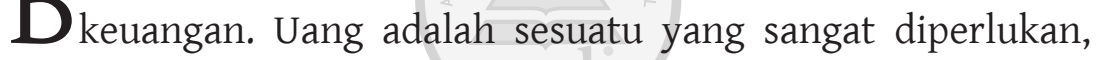
tetapi tidak menjadi faktor utama. Dalam Alkitab, ada 2.450 ayat yang berbicara soal uang dan turunannya, empat setengah lebih banyak dari doa dan iman (500 ayat). Bahkan, Yesus secara terang-terangan berbicara bahwa kita tidak bisa menyembah mamon dan Tuhan bersama-sama (Mat. 6:24).

Perkataan Agur bin Yake dalam Amsal 30:8-9 perlu diperhatikan:

"Jauhkanlah dari padaku kecurangan dan kebohongan. Jangan berikan kepadaku kemiskinan atau kekayaan. Biarkanlah aku menikmati makanan yang menjadi bagianku. Supaya, kalau aku kenyang, aku tidak menyangkal-Mu dan berkata: Siapa TUHAN itu? Atau, kalau aku miskin, aku mencuri, dan mencemarkan nama Allahku" (Bandingkan dengan doa Bapa Kami) 


\section{MISIOLOGI}

Ternyata, kekayaan yang berlebihan membuat kita melupakan Tuhan dan kemiskinan yang terus-menerus juga menjadi ganjalan, terlebih lagi dalam pelayanan misi.

Untuk menghindari penyalahgunaan keuangan, pengalaman Yesus adalah model dan teladan misi yang luar biasa. Selama dalam pelayanan, Tuhan Yesus tidak dipusingkan dengan beban hidup maupun hal-hal keuangan. Hal itu karena Dia selalu didampingi oleh orang-orang yang siap berkurban.

Paulus sebagai rasul penanam jemaat juga sangat mengerti hal ini. Paulus tidak pernah membebani jemaatnya. Bahkan, ia yang terlebih dahulu memberi untuk pelayanan. Paulus mengerti betul bahwa panggilannya adalah kehendak Allah sebagaimana yang dinyatakannya dalam 2 Timotius 1:1,

"Dari Paulus, rasul Kristus Yesus oleh kehendak Allah untuk memberitakan janji tentang hidup dalam Kristus Yesus,"

Paulus juga mengerti bahwa pelayanan itu diberikan oleh Tuhan dan ia telah "ditetapkan" sebagai pemberita Injil, rasul, dan guru. Bagi utusan misi, ketika kita mengerti hal-hal tersebut, kita akan tahu bahwa Dia adalah Allah penyedia. Kitab 2 Timotius 1:11-12 berkata:

"Untuk Injil inilah aku telah ditetapkan sebagai pemberita, sebagai rasul dan sebagai guru. Itula h sebabnya aku menderita semuanya ini, tetapi aku tidak malu; karena aku tahu kepada siapa aku percaya dan aku yakin bahwa Dia berkuasa memeliharakan apa yang telah dipercayakan-Nya kepadaku hingga pada hari Tuhan."

Dari sini dapat dipelajari bahwa faktor kesetiaan dalam panggilan dan pelayanan (1 Tim. 1:12; 18-19; 2 Kor. 6:3-10, 
Ibr. 10:32-36) membuat utusan misi betul-betul menghargai panggilan yang sudah Tuhan percayakan.

Faktor lain yang tidak kalah penting adalah menjaga hubungan yang benar dengan Bapa di surga (Mat. 6;33; 2 Kor. 13:5-10; 2 Tim. 2:15-21). Selain itu, pelayan utusan misi harus bisa menjadi contoh buat yang lainnya (2 Tim. 3:10-11; 1 Tim. 4:12; Tit. 2:7-8).

Jadi, sebelum kita bicara soal keuangan misi, hendaknya unsur-unsur ini sudah ada dalam diri kita: Berpegang teguh pada iman, sebagai tentara Allah yang baik (2 Tim. 2:3-4), bertekun dalam penderitaan/Enduringin suffering (Ibr. 10:32-36), kekuatan dalam ketekunan dan hubungan yang benar dengan Tuhan.

\section{A. Model-model Keuangan Misi'}

\section{Ministry by Prayer Only/hidup dengan iman, George Muller of Bristol (England; 1805-1898)}

George adalah hamba Tuhan yang terus mengandalkan imannya kepada Tuhan. Ia yakin betul hubungan yang benar membuat mujizat terjadi setiap saat. Selama dalam pelayanannya ini yang telah dilakukan:

Menampung 10.024 anak panti, membangun 117 sekolah, menyekolahkan 120.000 anak dan telah melakukan $300.000 \mathrm{~km}$ total perjalanan misi. Peristiwa yang pernah diceritakan sebagai

1 Model-model keuangan misi adalah kesimpulan dari berbagai konsep keuangan yang disimpulkan oleh penulis yang diambil dari bahan ajar "Living by Faith" oleh Dr. Tan Kok Beng, BIU Singapore dan sumber-sumber lainnya. 
kesaksian hidupnya adalah: suatu hari di panti asuhan semua bahan makanan telah habis, baik susu maupun roti. Para petugas dan pelayan menghadap untuk mengusulkan agar proposal bantuan kemanusiaan diberikan kepada orang-orang kaya. Namun, hal ini ditentang habis-habisan oleh George Mueller. Ia hanya mengatakan, kalau pelayanan itu Tuhan yang memberi dan Tuhan juga yang bertanggung jawab untuk keperluan pelayanan. Kita hanya berdoa saja. Keesokan harinya, semua anak anak panti telah duduk di meja makan masing-masing dengan piring dan gelas yang kosong, George meminta mereka untuk berdoa seperti biasa, mengucap syukur untuk berkat yang diberikan. Setelah selesai doa, pintu asrama diketok dan mereka melihat orang mengantar roti berbakul-bakul. Tentu penjaga panti menolak karena mereka tidak memesan roti dari bakeri. Namun petugas roti hanya menyatakan kalau kemarin malam ada yang memesan roti dalam jumlah yang besar tetapi yang memesan tidak datang-datang untuk mengambil roti sehingga daripada roti itu rusak maka lebih baik diantar dan disumbangkan ke panti asuhan. Sekarang, setiap anak di meja makan memiliki roti untuk dimakan. Tidak berapa lama, tiba tiba tukang susu datang dengan susu berember-ember. Pemilik peternakan adalah seorang anak Tuhan dan ia hanya mengatakan kalau Roh Kudus pagi-pagi membangunkannya dan meminta seisi rumah memerah susu dan mengantarkannya ke panti asuhan. Sekarang semua piring dan gelas sudah terisi makanan dan minuman. Pelayanan hanya didasarkan iman dan hidup dari iman. 


\section{Hudson Taylor (1832-1905), Hidup dari Iman dan sumbangan sukarela}

Hudson Taylor memulai pelayanan misi Cina daratan dengan satu tekad yang luar biasa. Konsep keuangan pelayanannya adalah dengan iman dan pemberian sukarela dari anak-anak Tuhan. Setiap keperluan dibawa dalam doa dan meminta kepada pribadi tidak diizinkan. Tidak boleh besar pasak dari pada tiang dan berharap penuh kepada Tuhan.

Selama pelayanan di Cina, hamba Tuhan ini telah memimpin 800 tenaga misi di China, membaptis 18.000 orang Cina, membangun 125 sekolah dan 300 tempat pelayanan di 18 provinsi dengan 500 tenaga lokal. Kalimat favoritnya dalam pelayanan adalah "God uses men who are weak and feeble enough to lean on Him" (Tuhan memakai orang-orang yang lemah dan cukup lemah untuk bersandar kepada diri-Nya). Hudson Taylor menemukan dalam hidupnya: "I have found there are three stages to every great work of God: first it is impossible, then it is difficult, then it is done" (Saya telah menemukan ada tiga tahap untuk setiap pekerjaan besar Allah: pertama adalah mustahil, kemudian sulit dan selanjutnya selesai saja), “God's work done God's way will never lack God's supply" (Pekerjaan Tuhan yang dilakukan dengan cara Tuhan tidak akan pernah kekurangan suplai dari Tuhan).

\section{William Carey (1761-1834), Misionaris Baptis yang di kirim ke India.}

Konsep pelayanan Carey dikenal dengan "Rope holders ConceptMinistry maintained by prayer partners \& supporters." Carey percaya pelayanan itu seperti tali timba, ada yang diutus (timba), ada 
yang mengikat (tali) dan ada yang menopang. Selain diutus, orang perlu yang menopang (dana) dan ada yang mendoakan. Konsep dari Carey yang menjadi bapak bangsa India dalam hal iman Kristen ini adalah Expect great things from God, attempt great things for God (Harapkan hal-hal besar dari Allah dan upayakan hal-hal besar bagi Allah).

\section{Oral Roberts (1918-2009)}

Hamba Tuhan besar dari Amerika ini mempunyai konsep, harus ada lembaga pendukung pencari dana untuk pelayanan misi di luar gereja. Persembahan khusus diambil dari setiap pertemuan dan permohonan ditujukan kepada orang tertentu yang dapat mendukung pelayanan. Pemasukan organisasinya adalah US\$120 juta/tahun dengan 2300 karyawan.

\section{John Edmund Haggai (1940-...), Pendiri Haggai Institute}

Hamba Tuhan yang masih hidup sampai sekarang ini mengusulkan: Financial management concept (fund raising through banquets, regular appeal letter, person to person appeal). Artinya, pencarian dana dilakukan melalui jamuan makan malam, surat-surat permohonan dukungan secara resmi dan permohoman langsung kepada orang-orang tertentu. Terbukti Haggai sampai hari ini telah membiayai lebih dari 50.000 pemimpin seluruh dunia untuk dilatih secara cuma-cuma di Maui, Hawaii.

\section{William Booth (1829-1929)}

Pendiri Bala Keselamatan yang dikenal dengan sebutan nabi orang miskin, mempunyai konsep penjangkauan jiwa yang sangat terkenal, yaitu "Go for Souls and go for the worst." William 
Booth pernah mengalami masa-masa sulit sehingga pada 1865-1892, ia mengizinkan dana-dana ilegal untuk dibawa ke altar Tuhan untuk dikuduskan dan dipakai dalam pelayanan (Salvation army radical concept of church financial). Dalam International Accounting history Conference di Osaka Jepang, hal ini dipublikasikan dalam jurnal yang ditulis dengan judul "the legitimizing Power of Financial Statements in the Salvation Army in England, 1865-1892." Dengan kata lain, konsep dan sistem yang diajarkan William Booth zaman itu mungkin tanpa kita sadari seperti "Money laundring" yang dilakukan dalam gereja modern sekarang.

\section{B. Konsep Keuangan Saat Ini}

Penulis sebagai gembala dan juga praktisi misi lapangan menggunakan konsep yang juga disesuaikan dengan kebutuhan dan perkembangan sekarang. Untuk para hamba Tuhan sepenuh waktu yang bekerja di kantor dengan Sistem Gaji: Gaji dibayarkan kepada Pengerja Fulltime berdasarkan Kualifikasi, Posisi, Pengalaman Kerja, dan Tanggung Jawab

Bagaimana dengan kebutuhan dana di lapangan?

Sistem yang dibangun dalam pengumpulan dana misi sebagai gereja yang otonom dan independen, pertama sekali tetap memerhatikan kewajiban kepada sinode. Sejak pertama kali diutus sebagai gembala, tidak pernah melupakan kewajiban

2 Irvine Helen, The Legitimizing Power of Financial Statements in the Salvation Army in England, 1865-1892, Research Paper University of Wollongong Australia. The article was originally published in The Accounting Historians Journal, 29 (1), Juni 2002:1-36. 
sumbangsih bagi sinode, yang artinya persepuluhan kepada gereja induk tidak pernah diabaikan.

Sedangkan sistem keuangan yang dilakukan adalah sebagai berikut:

Setiap minggu, setiap dana persembahan yang masuk selain disisihkan untuk sinode juga disisihkan untuk pekerjaan misi sebesar $10 \%$ setiap minggu. Setiap kelompok sel yang mengumpulkan persembahan, 50\% wajib dimasukkan ke dana misi gereja (25\% untuk kas kelompok sel sendiri dan 25\% untuk departemen). Setiap lembaga-lembaga atau kegiatan-kegiatan yang merupakan unit "bisnis" dari gereja seperti sekolah (Paud, SD, SMK), Bimbingan Belajar, pelatihan vokasional, semua keuntungan murninya dibagi ke departemen Misi sebanyak $30-50 \%$.

Sumbangan-sumbangan sukarela, dari luar gereja selain pembangunan akan masuk ke kas misi. Operasional gereja di ambil dari persembahan rutin mingguan gereja.

Setiap cabang gereja yang telah mandiri, menyisihkan juga dana-dana misi. Setiap bulan 1 kali akan diadakan ekstra kolekte untuk dana misi.

Dengan demikian, dana misi yang terkumpul akan cukup untuk membiayai tenaga-tenaga misi lapangan.

Selain itu, diadakan juga program-program khusus yang melibatkan semua unsur dalam gereja, anak-anak sampai orang dewasa seperti celengan misi, minggu misi, dan lain sebagainya.

Sistem untuk membiayai pelayanan misi adalah sebagai berikut: 
Setiap perintisan baru gereja regular, akan didukung selama 2 tahun, di mana setiap 6 (enam) bulan, akan dikurangi $25 \%$. Namun untuk pengutusan ke suku-suku yang belum terjangkau dan medan-medan yang sulit yang tidak memungkinkan pendirian jemaat regular, gereja lokal akan mendukung secara penuh (fully support). 


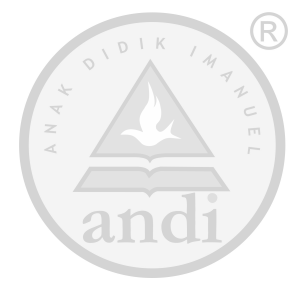




\section{Merekrut Tenaga Misi \& Fakta-fakta yang Perlu Diketahui}

Pelayanan misi tentu dimulai dengan doa. Doa merupakan Pelemen krusial yang harus ada. Selain doa, sumber daya manusia diperlukan. Tidak mudah untuk mendapatkan tenaga misi yang siap pakai. Bagaimana memulai untuk merekrut?

\section{A. Penyataan Visi}

Amsal 29:18a: "Bila tidak ada wahyu, menjadi liarlah rakyat" "Where there's no vision people perish").

Membagi visi kepada setiap orang merupakan hal yang sangat penting. Membagi visi itu sangat sederhana. Ketika Tuhan menaruh di hati tentang sesuatu daerah atau penjangkauan daerah tertentu, setelah didoakan, hal itu akan dibagikan kepada jemaat dan tim yang ada bahkan di bawa dalam khotbah-khotbah yang ada di mana pun, disertai dengan data-data pendukung, tentu pertama-tama pada lingkaran dalam (orang-orang dekat), kemudian dibagikan dalam cakupan lebih luas. Ketika visi dibagikan, biasanyahal itu diresponi 


\section{MISIOLOGI}

dengan berbeda oleh pendengar: yang pertama, "no comment" karena tidak mengerti, yang kedua bertanya walaupun tidak merespons, yang ketiga diam tanda tidak setuju tetapi ada juga yang menanggapi tetapi harus digumuli lebih lagi.

Visi menentukan tindakan dan hasil. Jadi, visi harus dibagi sesering mungkin dan harus terus-menerus diucapkan (terus-menerus diucapkan akan membangkitkan iman). Bagi penulis sendiri, hal itu dibagikan dalam ibadah Minggu dalam penyampaian firman, dalam pertemuan-pertemuan sel, maupun pertemuan dalam skala nasional karena visi memang sangat penting. George Barna dalam bukunya The Power of Vision mengatakan: "Vision for ministry is a reflection of what God wants to accomplish through you to build His Kingdom." ${ }^{1}$ Artinya, visi untuk pelayanan adalah refleksi dari hal yang Allah ingin capai melalui Anda untuk membangun Kerajaan-Nya. Bagaimanapun, hal membagikan visi juga tidak kalah penting.

\section{B. Perekrutan}

Ladang yang telah menguning dan siap dituai adalah visi 2000 tahun yang lalu yang disampaikan Tuhan Yesus.

Yohanes 4:35 berkata:

"Bukankah kamu mengatakan: Empat bulan lagi tibalah musim menuai? Tetapi Aku berkata kepadamu: Lihatlah sekelilingmu dan pandanglah ladang-ladang yang sudah menguning dan matang untuk dituai."

Dari zaman Yesus sampai hari ini, ladang tuaian tidak menjadi masalah, tetapi yang menjadi masalah adalah para

1 George Barna, Kekuatan Sebuah Visi(Ventura, CA: Regal Book,1992), hal.15. 
penuainya. Penuai perlu dicari dan direkrut. Perumpamaan dalam Matius 20:1-7 yang bercerita mengenai pemilik kebun anggur mencari para penuai adalah contoh konkrit. Penuai harus direkrut. Kitab Matius 9:37 berkata: "Tuaian Memang banyak, tetapi pekerja sedikit." Begitu juga Lukas 10:2b menyarankan agar: "Karena itu mintalah kepada Tuan yang empunya tuaian, supaya Ia mengirimkan pekerja pekerja untuk tuaian." Ketika visi dibagikan, dan ada yang merespons, hal ini harus di follow-up dan diyakinkan. Calon kandidat misionaris atau utusan misi akan dilatih dalam pelatihan singkat bagi mereka yang telah terjun dalam pelayanan selama 3,5 bulan dan pendampingan selama 6 bulan sebelum diutus.

\section{Pelatihan}

Pelatihan sangat diperlukan untuk memperlengkapi para Hamba Tuhan yang akan diutus. Dengan pelatihan, kapasitas seseorang akan diperbesar dengan berbagai pengalaman dan pengertianpengertian baru. Pelatihan juga akan membuat panggilan jiwa atau Compassion itu ada. Melalui pelatihan, karakter juga akan terbentuk dan akhirnya menghasilkan komitmen yang dalam sebelum diutus (Lihat studi kasus pelatihan POAB).

\section{Pengutusan}

Setiap utusan misi yang sudah dilatih sehingga faktor penempatan yang sesuai dengan kebutuhan dan skill adalah kunci suksesnya pelayanan. Melalui pemusatan pelatihan, pemantauan, dan mentoring, serta pengamatan yang cermat, barulah seseorang akan diutus. 


\section{MISIOLOGI}

Pengutusan ada beberapa kategori (baik dalam maupun luar negeri):

- Misi Regular: pengutusan penanaman gereja denominasional (sesuai dengan denominasi)

- Misi Non-regular: Misi khusus penjangkauan suku terabaikan (unreached people group)

- Misi ke bangsa-bangsa

- Misi ke suku-suku terasing pedalaman

- Misi ke kantong-kantong Kristen membantu gerejagereja lokal yang ada dengan mengirim guru, penginjil, dan pendoa.

\section{E. Pemerhati}

Perhatian terhadap utusan misi adalah poin penting. Ada banyak gereja melupakan tanggung jawab ini. Ketika pengutusan dimulai, sering kali hal yang terjadi selanjutnya adalah terputus di tengah jalan. Perhatian yang harus diberikan di antaranya:

- Kunjungan berkala ke tempat kerja utusan misi

- Pertemuan berkala di wilayah terdekat, fellowship, dan doa bersama.

- Rekreasi bersama dan retreat

- Mission Trip bersama rekan-rekan misi ke satu daerah baru

- Tunjangan ladang misi: tabungan, beasiswa, dan investasi 
- Komunikasi rutin untuk membangun kebersamaan dan saling mendoakan

- Penerimaan ketika masa tugas selesai.

\section{Fakta-fakta yang Perlu Diketahui}

Sebagai utusan misi yang berada di lapangan selama bertahuntahun, saya sering kali menyadari ada banyak faktor atau kendala yang membuat pelayanan gagal. Berdasarkan data survei dan pengamatan serta penelitian yang saya pelajari setelah mengirim tenaga misi sejak 2006 sampai sekarang serta data-data umum dan pengamatan di antara rekan-rekan misi di lapangan, ada beberapa poin yang perlu kita pelajari supaya tidak mengulang kesalahan yang sama.

\section{A. Lubang yang Harus Dihindari}

- Cinta akan uang

- Kurangnya komunikasi dengan pemimpin

- Arogansi. Sering kali, pelayanan yang sukses membuat kita bangga dan menyombongkan pelayanan dan merasa tidak perlu orang lain/pemimpin

- Dosa seksual dan nafsu percabulan

- Bosan, kesepian, dan kecemasan akan masa depan sering membuat utusan misi gagal

- Gagal fokus karena diberkati dan di sisi lain ada pekerjaan sampingan sehingga lari dari fokus utama 


\section{MISIOLOGI}

- Terlalu lelah mengerjakan sendiri dan bekerja secara berlebihan

- Puas dengan diri sendiri: Terlalu nyaman dan diberkati sehingga lupa akan panggilan sesungguhnya

- Memaksakan kebiasaan/ budaya kita untuk diterapkan di ladang misi.

\section{B. Fakta-fakta Tambahan yang Perlu Diketahui}

Menurut Tafsiran Kisah Para Rasul, para murid yang sudah tersebar (karena aniaya) keluar memberitakan firman ke mana pun mereka pergi. Hasil dari pemberitaan tersebut banyak gereja-gereja baru dilahirkan. Gereja di Antiokhia juga didirikan oleh murid-murid yang tersebar karena penganiayaan, yang namanya tidak disebutkan dan tidak dikenal. ${ }^{2}$ Selain Gereja Antiokhia yang ditanam oleh para misionaris gereja Yerusalem, ada juga banyak gereja yang ditanam oleh Gereja Antiokhia (lihat pelayanan Rasul Paulus), misalnya seperti Gereja Galatia, Gereja Efesus, Gereja Filipi, Gereja Korintus, dan Gereja Roma. Gereja mula-mula telah melakukan penanaman gereja dan bahkan penanaman gereja merupakan hal utama yang dilakukan oleh para rasul ataupun misionaris gereja mula-mula tersebut. Oleh karenanya, sebagai kelanjutan dari gereja yang misioner, kita juga harus melakukan penanaman gereja-gereja baru.

Gereja yang ada saat ini tampaknya sangat jauh dari zaman gereja mula-mula. Gereja sekarang cenderung menjadi

2 Kisah Para Rasul, (Karawaci: Harvest International Teological Seminary), hal. 101. 
pusat perubahan hidup "pribadi" dan bukan menjadi gereja yang missioner.

Menurut data yang ada, saya dapat menyampaikan analisis saya sebagai berikut: ${ }^{3}$

1. Jika kita membandingkan dengan kenyataan yang ada, hampir semua misionaris mengerjakan penanaman gereja di daerah yang sudah banyak orang Kristennya.

2. Penjangkauan lintas budaya kebanyakan hanya menjangkau kaum sesamanya, tipe penginjilan E2, menjangkau sesama kaum hanya lintas geografi.

3. Gereja yang ditanam rata-rata model $\mathrm{C} 1$, yaitu mengikuti budaya gereja pengutus.

4. Foreign Missionaries/misionaris asing maupun lokal menjangkau daerah-daerah yang sudah menjadi "Kristen" atau sudah banyak orang percaya nya (Lihat diagram di sebelah)

\section{World Population Foreign Missionaries}

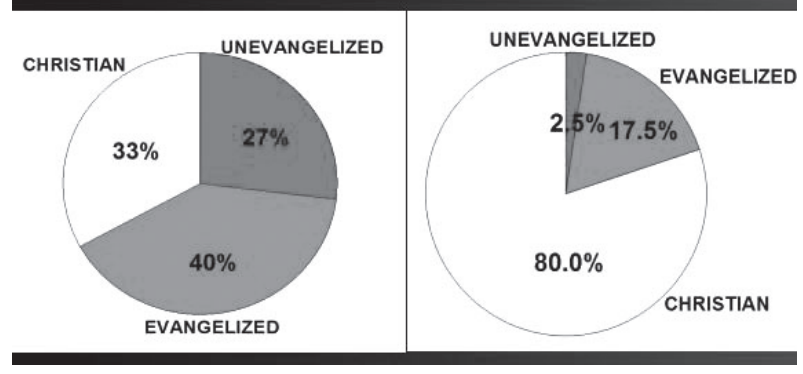

3 Data diambil dari Joshua Project dan hasil research team Gordon Cornwell University, 2013. 
Missionaries sent and received, 2010

\begin{tabular}{|c|c|c|c|c|c|c|c|}
\hline \multicolumn{2}{|c|}{ Most sent } & \multicolumn{2}{|c|}{$\begin{array}{l}\text { Most sent per million } \\
\text { church members }\end{array}$} & \multicolumn{2}{|c|}{ Most received } & \multicolumn{2}{|c|}{$\begin{array}{l}\text { Most received per } \\
\text { million population }\end{array}$} \\
\hline Country & Total & Country* & Total & Country & Total & Country & Total \\
\hline 1 United States & 127,000 & Palestine & 3,401 & United States & 32,400 & Micronesia & 4,779 \\
\hline 2 Brazil & 34,000 & Ireland & 2,131 & Brazil & 20,000 & Samoa & 4,167 \\
\hline 3 France & 21,000 & Nata & 1,994 & Russia & 20,000 & Tonga & 3,922 \\
\hline 4 Spain & 21,000 & Samoa & 1,802 & DR Congo & 15,000 & Netherlands Ant & 3,317 \\
\hline 5 ltaly & 20,000 & South Korea & 1,014 & South Africa & 12,000 & Guam & 2,833 \\
\hline 6 South Korea & 20,000 & Belgium & 872 & France & 10,000 & French Polynesia & 1,612 \\
\hline 7 United Kingdom & 15,000 & Singapore & 815 & Unted Kingdom & 10,000 & USVirgin Islands & 1,532 \\
\hline 8 Germany & 14,000 & Tonga & 619 & Argentina & 10,000 & Belize & 1,438 \\
\hline 9 india & 10,000 & United States & 614 & Chile & 8,500 & Vanuatu & 1,399 \\
\hline 10 Canada & 8,500 & Netherlands & 602 & India & 8,000 & New Caledonia & 1,344 \\
\hline \multirow{2}{*}{\multicolumn{2}{|c|}{ Costies getater tran 100.000 pcpulation }} & \multicolumn{6}{|c|}{ 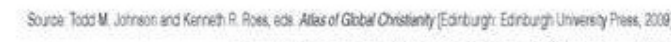 } \\
\hline & & & & Crite for the Slay of Gecel & & 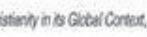 & $\mathrm{rex}$ \\
\hline
\end{tabular}

Diagram Penyebaran Misionaris di dunia. Data diambil dari Joshua Project dan Gordon Cornwell Theology Seminary. ${ }^{4}$

5. Pelayanan misi mayoritas dilakukan oleh lembaga misi bukan gereja. Pertemuan dunia di Batam 10-13 Mei, GCPN (Global Church Planting Network) dan GACX (Global Alliance Church Multiplication) diikuti 45 negara, dan 148 peserta, semua mayoritas dari lembaga-lembaga misi, hanya 2 (dua) peserta dari gereja lokal negara mereka.

6. Setiap 1 US\$ persembahan (setara 15.000 rupiah) yang dikumpulkan di gereja, dana yang dipakai untuk misi hanya US\$ 0,050 (hanya 5 cents, setara dengan Rp 750 saja). ${ }^{5}$

4 Christianity in Its Global Context, 1970-2020. Centre for the Study of Global Christianity, Gordon Cornwell, Theological Seminary.

5 Joshua Project 2010. 


\section{Mengapa Gereja Gagal Menginjili Dunia?}

- Musuh Firman Tuhan (the enemies of the góspel). Agama-agama palsu yang juga melakukan "penjangkauan", nasionalisme "picik" yang mengangkat sentimen SARA (Suku, Agama, Ras, dan Antar Golongan) dan juga ekonomi yang berkembang pesat merupakan musuh nomor satu pekabaran Injil.

- Penekanan pada dunia pendidikan yang berlebihan. Pendidikan yang dilakukan oleh gereja berkembang dengan pesat, tetapi ujung-ujungnya hanya bersifat komersialisasi. Hampir semua pendidikan yang dibuat atau didirikan lembaga gereja atau Kristen sangat mahal. Misi penjangkauan berubah menjadi misi ekonomi dengan dalih untuk mendukung pelayanan. Akhirnya, masyarakat sederhana yang mau sekolah hanya bisa menonton.

- Banyaknya pintu-pintu yang tertutup. Memang ada banyak pintu yang tertutup, tetapi sebenarnya yang perlu dilakukan gereja adalah melihat kesempatan di banyak pintu yang dibuka oleh Tuhan dengan berbagai krisis, baik bencana alam, politik, dan lain-lain.

- Tidak cukupnya gereja-gereja mencetak tenaga misi, kurangnya dana atau kurangnya kemampuan untuk merekrut dan melatih. Di samping itu, kurangnya data dan visi yang mendukung, membuat gereja-gereja ragu-ragu merekrut dan melatih (takut gagal). 


\section{MISIOLOGI}

- Tidak mengikuti strategi Alkitab paling praktis yang dilakukan Paulus (Pauline Method). Gereja hanya mencoba dan mencoba metode baru tanpa melihat metode Paulus yang paling praktis.

- Gereja tidak menyadari bahwa keselamatan perlu diterima setiap orang. Dunia yang terhilang begitu luas, sedangkan tanda kedatangan-Nya sudah semakin nyata. Gereja perlu memberi perhatian serius pada Kisah Para Rasul 4:12, dan Yohanes 4:16. (Lihat data \& gambar Affinity blok di bawah).

- Kurangnya penekanan "doa" pujian dan penyembahan. Sebagaimana strategi di Kisah Para Rasul, murid-murid banyak menghabiskan waktu berdoa sebelum terjun menginjil dan menjangkau. Menurut Ir. Niko Njotorahardjo, tanpa menara doa tidak akan ada penuaian. ${ }^{6}$ Sebagaimana yang diungkapkan dalam Matius 28:16-18 bahwa muridmurid menyembah Yesus dan Tuhan Yesus memberi kunci untuk pergi melaksanakan Amanat Agung.

- Kurangnya data pendukung dan sumber-sumber data.

Affinity Blok: Penyebaran penduduk dunia berdasarkan sosio budaya: 253 (People Clusters). Family peoples group. 16,448 Ethne/Suku berdasarkan negara

6 Pdt.Ir. Niko Nyotorahardjo: tanpa menara doa tidak ada penuaian; doa pujian penyembahan $24 / 7$, intim dengan Tuhan dan jika Tuhan ditinggikan, dia akan menarik banyak jiwa (Yoh. 12:32). Pesan ini senantiasa disampaikan dalam doa pelayan jemaat GBI Gatsu Jakarta. 


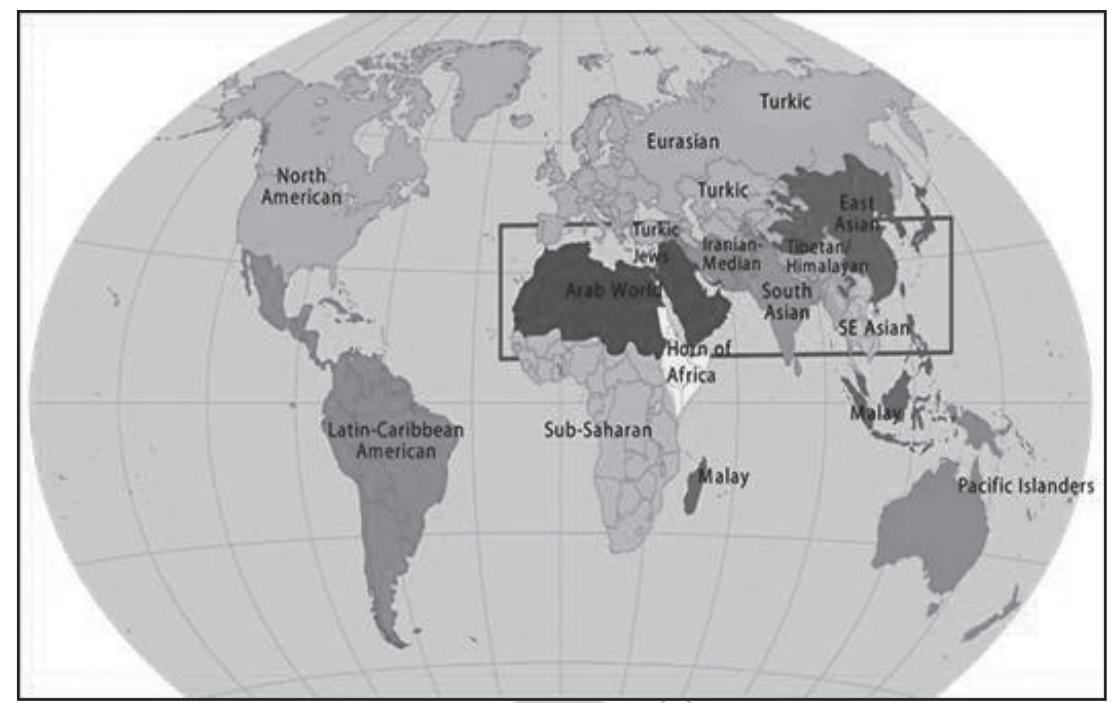

- $\quad 7,3$ Miliar Individu

- 16,448 Suku

- 6,909 Bahasa

- 237 Negara

Suku yang belum terjangkau sebanyak 7.081 suku dengan total 2,91 miliar individu yang tidak punya akses terhadap Injil.

Comparison of unreached people group assessments, 2013

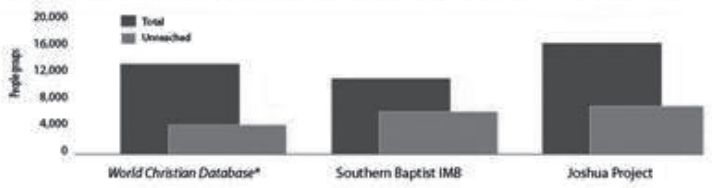




\section{MISIOLOGI}

Perbandingan suku-suku yang belum terjangkau di dunia berdasarkan tiga (3) lembaga Reserach Misi yang diakui dunia: Joshua Project, Southern Baptist International Mission Board, dan World Christian Database. ${ }^{7}$

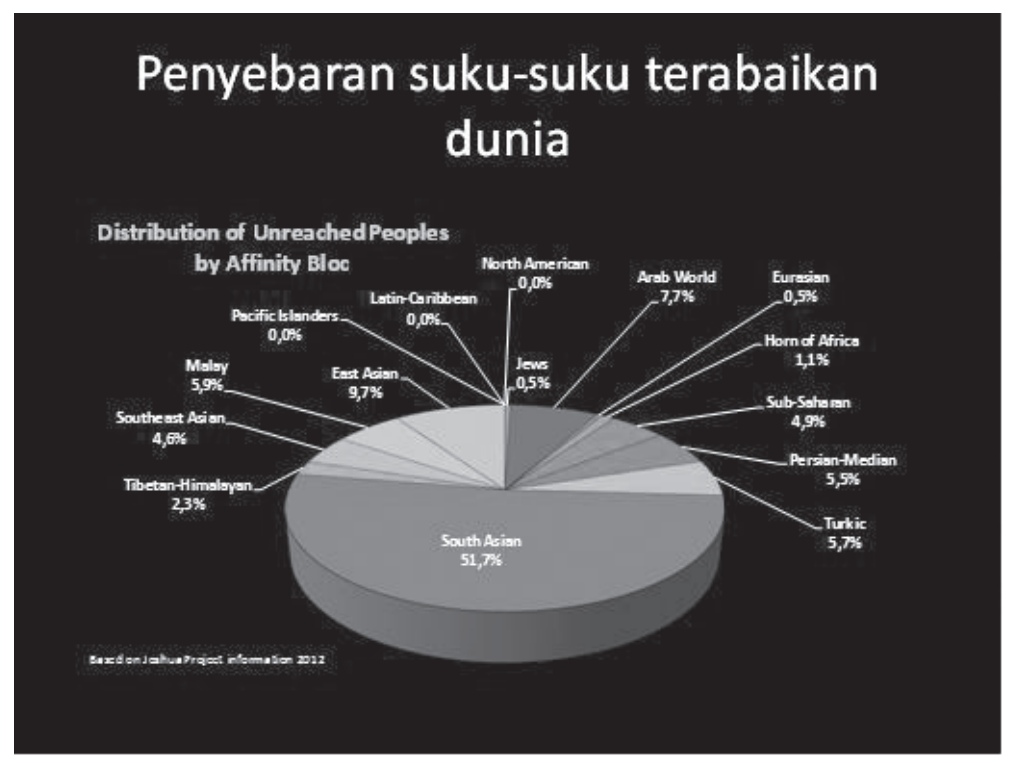

Penyebaran suku terabaikan berdasarkan region yang ada di dunia. ${ }^{8}$

7 Christianity in Its Global Context, 1970-2020. Centre for the Study of Global Christianity, Gordon Cornwell Theological Seminary.

8 Joshua Project 2010. 


\section{Daftar Pustaka}

Amaladoss S.J., Michael. "The Image of Jesus in the Church in Asia," East Asian Pastoral Review 37/3 (2000).

Aritonang, Jan dan Clor de Jonge. Apa dan Bagaimana Gereja? Jakarta: PT. BPK Gunung Mulia, 1995.

Azwar, Sayifudin. Reliabilitas. Yogyakarta:Pustaka Pelajar, 1987.

Baker, David L. Mari Mengenal Perjanjian Lama. Jakarta: BPK Gunung Mulia, 1988.

Barna, George. Kekuatan Sebuah Visi. Jakarta: Yayasan Media Buana Indonesia, 1992.

Bavinck, J. H. An Introduction to the Science of Missions. New Jersey: Presbyterian and Reformed Publishing Company, 1960.

Blauw,Johannes. The Missionary Nature of the Church: A Survey of the Biblical Mission. 


\section{MISIOLOGI}

Boiliu, Noh. Tulisan: Sebagai dosen tetap di Fakultas Keguruan dan Ilmu Pendidikan (FKIP), Prodi PAK pada Univ. Kristen Indonesia, Jakarta. Juga sebagai pengajar di STT REAL Batam, STT Bethel The Way Jakarta dan STT Apollos Jakarta.

_-_-_, Memasarkan Gereja.Bandung: Yayasan Kalam Hidup, 1988.

Borthwiek, Paul. Pemberitaan Injil Tugas Siapa? Bandung: Yayasan Kalam Hidup, 1993.

Bosch, David J. Transformasi Misi Kristen, Sejarah Teologi Misi Yang mengubah Dan Berubah.Diterjemahkan oleh: Stephen Suleeman.Jakarta: PT. BPK Gunung Mulia, 1988.

Bradshaw, Bruce. Bridging The Gap, Evangelism, Development and Shalom. California, USA: Published by Marc, 1984.

Castilo, Met. Theologi Misi Alkitabiah. Inc. Antipolo, Rizal, Filipina: STII- Jakarta, 2001.

Charles,MottStephen. Biblical Ethics And Social Politic Change. London: Oxford University Press, 1982.

C. M. Edward Jesudhas. Ethnography Report OfChamars of India and Special Attention to North India.Singapore: BIU Singapore, 2016.

Cook, Harold R. An Introduction to Christian Missions. Chicago: Moody Press, 1974.

Daiton, Martin B. Gereja Milik Siapa? Jakarta:Yayasan Komunikasi Bina Kasih/OMF, 1994.

Dawson, David L. Memperlengkapi Kaum Awam. 10 Jilid. Yogyakarta:

Yayasan Andi, 1997. 
Dayton, Edward R., dan Samuel Wilson. Unreachead Peoples' 82. Illinois: David C. Cook Publishing Company,1982.

De Kuiper, Arie. Missiologia: Ilmu Pekabaran Injil. Jakarta: BPK Gunung Mulia, 1996

De Lacy, O'Leary. Islam at the Crossroad. London, 1923.

Dixon, R. Tafsiran Kisah Para Rasul. Cetakan ke-4. Malang: Gandum Mas, 1997.

Drane, John. Introducting The Old Testament. Sydney: Alion Book, 1989.

Duewel, WesleyL. Menjangkau Dunia Melalui Doa. Bandung: Yayasan Kalam Hidup, 1995.

Ensiklopedi Alkitab Masa Kini. Jilid I: A-L. Cetakan ke-5.Jakarta: Yayasan Bina Kasih, 2003.

Faisal, Sanapiah. Metode Penelitian Pendidikan.Surabaya: Usaha Nasional, 1982.

Garrison, David. How God is Reedeming Lost World.Southern Baptist Church, 2013.

Gerald. "The Beginnings of Church Discipline." Dalam Understanding Paul's Ethics Politic. Editor Bian S. Rosner. Grand Rapids, MI: William B. Eerdmanns Publishing Company, 1995.

Girber, Vergil. Pedoman Pertumbuhan Gereja Penginjilan. Bandung: Yayasan Kalam Hidup, 1992.

Glenny, W. Edward dan William H. Smallman. Missions in a New Millenium: Change and Challenges in World Missions. Grand Rapids: Kregel Publications, 2000. 


\section{MISIOLOGI}

Glover, Robert. Menjawab Tantangan Amanat Agung. Yogyakarta: Yayasan Andi, 1997.

Green, Denis. Pengenalan Perjanjian Lama. Malang: Penerbit Gandum Mas, 2000.

Habecker, Eugene B. The Other Side of Ledership.USA: Victor Books, 1987.

Halim, Makmur. Gereja di Tengah-tengah Perubahan Dunia. Malang: Penerbit Gandum Mas, 2000.

, Theologia Kontekstualisasi, Jakarta; STT Institut Injili Indonesia, 1999. , Dinamika-dinamika Perubahan. Jakarta; STT Institut Injili Indonesia, 2000.

Hendricks, HowardG. Beritakan Injil Dengan Kasih. Jakarta: BPK Gunung Mulia, 1986.

Herlianto. Gereja Modern Mau ke Mana?Bandung: Yayasan Kalam Hidup, 1995.

Haggai, John. Lead On! Leadership That Endures in A changing World. Waco Texas: World Publishing, 1986.

Hinson, David F. Sejarah Israel pada Zaman Alkitab. Jakarta: BPK Gunung Mulia, 2000.

Horst, Balzdan Gerhard Schneider. Exegetical Dictionary of The New Testament. Volume 3. Jakarta: BPK Gunung Mulia, 1993. Hutabarat, Hardy. Mentoring dan Pemuridan.Bandung: Kalam Hidup, 2014. 
Irvine, Helen. The Legitimizing Power of Financial Statements in the Salvation Army in England, 1865-1892. University of Wollongong.

Indra, Ichwei. Pola Gereja Perjanjian Baru. Cetakan I. Bandung: Lembaga Literatur Baptis, 1998.

Jensen, Ron. Dinamika Pertumbuhan Gereja. Cetakan I. Malang; Penerbit Gandum Mas, 1996.

Johnstone, Patrick. The Church Is Bigger Than You Think. Great Britain: Christian Focus Publications/WEC, 1998.

Johnstone, Patrick dan Jason Mandryk. Operation World: $21^{\text {st }}$ Century Edition. Grand Rapids: Zondervan Publishing House, 2001.

Jose, Miranda. Marx and The Bible: A Critique of The Philosophy of Oppresion. Maryknoll: Orbis Book, 1974.

Joshua Project 2012.

Kamus Besar Bahasa Indonesia. Edisi kedua. Jakarta: Balai Pustaka, 1991.

Kane, Herbert J. Christian Missions in Biblical Perspective. Grand Rapids: Baker Book House, 1976.

Kisah Para Rasul, Diktat Harvest International Theological School, Karawachi 2008.

Kruger, Th. Muller. Sejarah Gereja di Indonesia. Jakarta: BPK Gunung Mulia, 1966.

Kennedy, JamesD. Ledakan Penginjilan. Jakarta: E.E. Internasional III, 1970. 


\section{MISIOLOGI}

Ladd, George Eldon. Injil Kerajaan. Malang: Penerbit Gandum Mas, 1994.

Lindsell, Harold. The Church Worldwide Mission. Waco, Texas, USA; Word Books, 1966.

. Theologia Pertumbuhan Gereja. Jakarta: Sekolah Tinggi Teologia Injili Indonesia, 1999.

Mardiatmadja, B. S. Ekklesiologi. Cetakan II. Yogyakarta: Penerbit Kanisius, 1991.

Marbun, B.N. Kota dan Politik Indonesia (Kepulauan Riau) Masa Depan. Jakarta:Penerbit Erlangga, 1990.

McGavaran, Donald A. Church-Planting Movement Within Every People: The Key to Reaching Every People and Every Person. 1995

Sriyanto S.J., M. Wujud Gereja Asia (Seri Pastoral 174). Jogjakarta: Pusat Pastoral Jogjakarta, 1988.

Nicholls, Bruce J. In Word And Deed Evangelism And Social Responsibility. Michigan, USA: Willem B. Eerdmans Publishing Company, 1986.

Oentoro, Jimmy. Gereja Impian. Karawaci: Harvest Publications House, 2005.

Ogden, Greg. Pemuridan yang Mengubahkan. Surabaya: Perkantas, 2014.

Young,Pamela Dickey. “Theme and Variations: Gospel in a New Key”, Toronto Journal of Theology 12/2 (1996).

Paimoen, Eddy. Kerajaan Allah Dan Gereja. Bandung: Penerbit Agia Media, 1999. 
Payne, J.D. Discipleship in Church Planting: Some Guidelines to Move Us Forward.Wheaton, IL: Good News Publisher, 2011.

Patiassina, Jonathan. Gereja Rumah. Jakarta:GBI Rantepao Kasih Persaudaraan.

Phan,Peter C. "Jesus The Christ with Asian Face", Theological Studies 57/1 (1996).

Phillips, James M., dan Robert Coote. Toward The $21^{\text {st }}$ Century In Christian Mission. Grand Rapids, MI: Willem B. Eerdmans Publishing Company, 1995.

PJRN. Profil Doa Suku-Suku Yang Terabaikan. Jakarta: 2000.

Poon, M. S. Missiological Survey of Old Testament: An Introductory Guide. Singapore: All Nations Enterprise Pte Ltd., 2002.

Putman, Jim. Building Churches that Make Disciples. Colorado: NavPress, 2010.

, Memberitakan Injil Yang Tidak Berubah di Tengah Dunia Yang Sedang Berubah. Laporan Pelaksanaan Konsultasi Nasional PI, PGI, 1999.

Riley, Maria O.P. "Blessed Are They Who Hunger for Justice," New Theology Review 17/1 (2004).

Shenk, Wilbert R. The Transfiguration Of Mission, Biblical Theological And Hsitorical Foundation. Pennsylvania, Waterloo, Ontario: Herald Press, 1989.

Simeon, Ronny Daud.Bunga Rampai Gereja Yang Berdampak Menuju GBI Mantap, 2015.

Smeeton, Donald Dean. Gereja Tuhan dalam Dunia. Malang: Lembaga Kursus Tertulis International, 1978. 


\section{MISIOLOGI}

, Christian Mission in the Modern World. Bombay: Gospel Literature Service, 1990.

Tomatala, Yakob. Penginjilan Masa Kini. Jilid 1.Jakarta: YT Leadership Foundation, 1997.

Travis , John (a pseudonym). "The C1 to C6 Spectrum: A Practical Toolfor DefiningSixTypes of 'Christ-centeredCommunities' (' $C$ ') Found in the Muslim Context," Evangelical Missions Quarterly 34/4 (October, 1998).

Venema, H.Injil Untuk Semua Orang: Pembimbing ke dalam Ilmu Misiologi.Jakarta: Yayasan Komunikasi Bina Kasih, 1997.

Verkuyl, J.Contemporary Missiology: An Introduction. Grand Rapids, MI: William B. Eerdmans Publishing Company, 1978.

Vicedom, George F. The Mission of God: An Introduction to a Theology of Mission. Missouri: Concordia Publishing House, 1985.

Vinay, Samuel dan Sugden. Mission as Transformation, A Theology of The Whole Gospel. USA:Regnum Books International, 1999.

Voetius, Gisbertus.Politica Ecclesiastica (Pemerintahan Gereja) Dalam Injil Untuk Semua Orang. Jakarta:Yayasan Komunikasi Bina Kasih,1997.

White, John. Kepemimpinan yang Handal, Mencapai Sasaran dengan Doa, Keberanian dan Tekad yang Bulat. Bandung; Yayasan Kalam Hidup, 1995.

Wagner, Peter C. Memimpin Gereja Anda Agar Bertumbuh. Jakarta: Harvest Publication House, 1995. 
Wagner, C. Peter and Edward R. Dayton. Editor.Unreachead Peoples' 81. Illinois: David C. Cook Publishing Company, 1981.

Wagner, C. Peter. Strategi Perkembangan Gereja. Malang: Gandum Mas, 2003.

Winter, Ralph D."Four Men, Three Eras, Two Transitions: Modern Missions." Dalam Perspective on the World Christian Movement: A Reader, 1981.

Woga, Edmund. Dasar-dasar Misiologi, Yogyakarta: Kanisius, 2002. , Strategi Perkembangan Gereja. Malang:Penerbit Gandum Mas, 1994.

, Gereja Saudara Dapat Bertumbuh. Malang: Penerbit Gandum Mas, 1990. , Churchquake. California, USA: Regal Books, a division of Light Publications, 1999.

, The New Apostolic Churches. Ontario, California: Gospel Literature International, 1999.

------, Pertumbuhan Gereja dan Peranan Roh Kudus, Malang: Penerbit Gandum Mas, 1989. , Gereja-Gereja Rasuli yang Baru. Jakarta: Penerbit Yayasan Immanuel, 2001.

Warren, Rick. Pertumbuhan Gereja Masa Kini. Malang: Penerbit Gandum Mas. 2000.

Waymire, Bob dan C. Peter Wagner. Pedoman Survei Pertumbuhan Gereja.Cetakan I. Malang: Penerbit Gandum Mas, 1996. 


\section{MISIOLOGI}

Wongso, Peter. Tugas Gereja dan Misi Masa Kini. Cetakan III. Malang: Seminari Alkitab Asia Tenggara, 1999.

Yeuw Choo Lak. "Doing Theology in Asia: The Narrative Way", Asian Journal of Theology 57 (1994). 


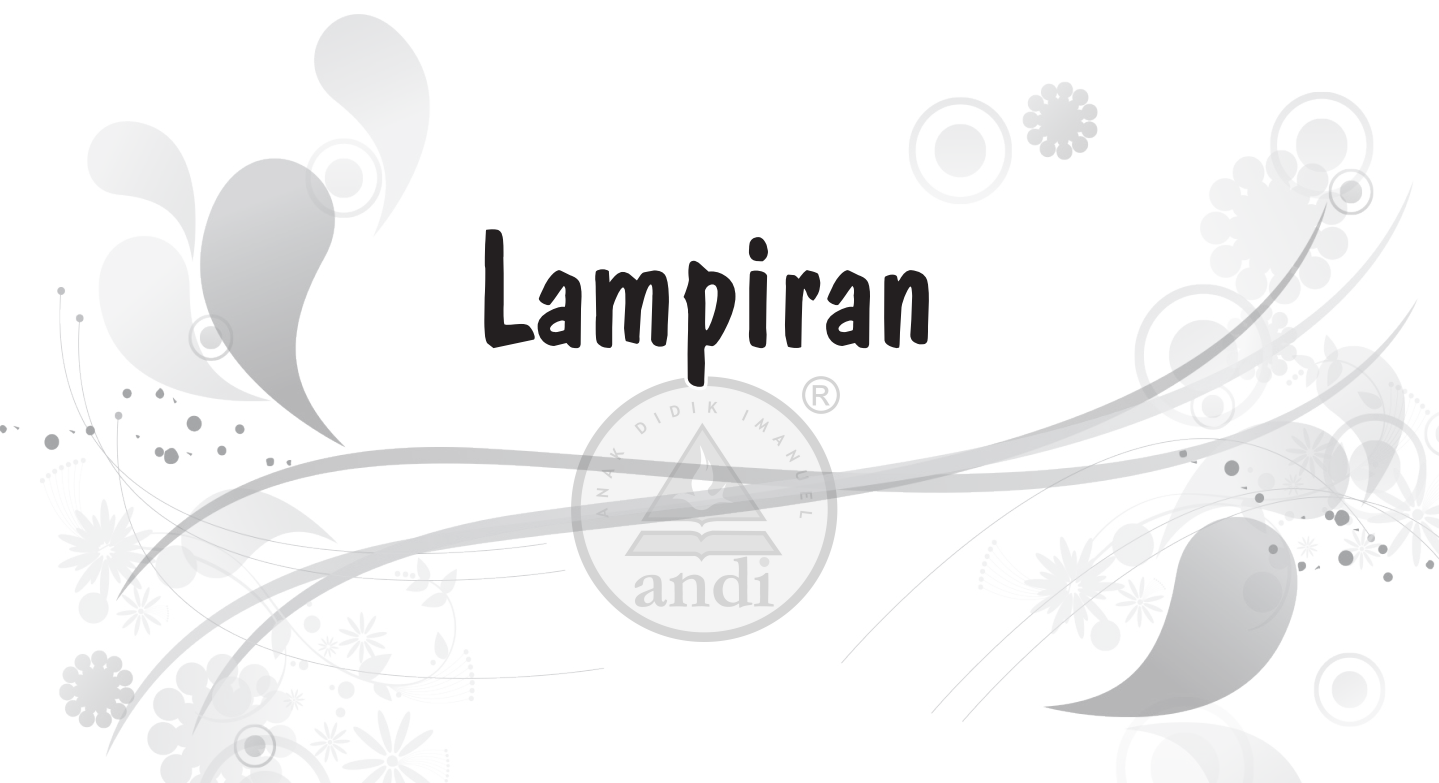




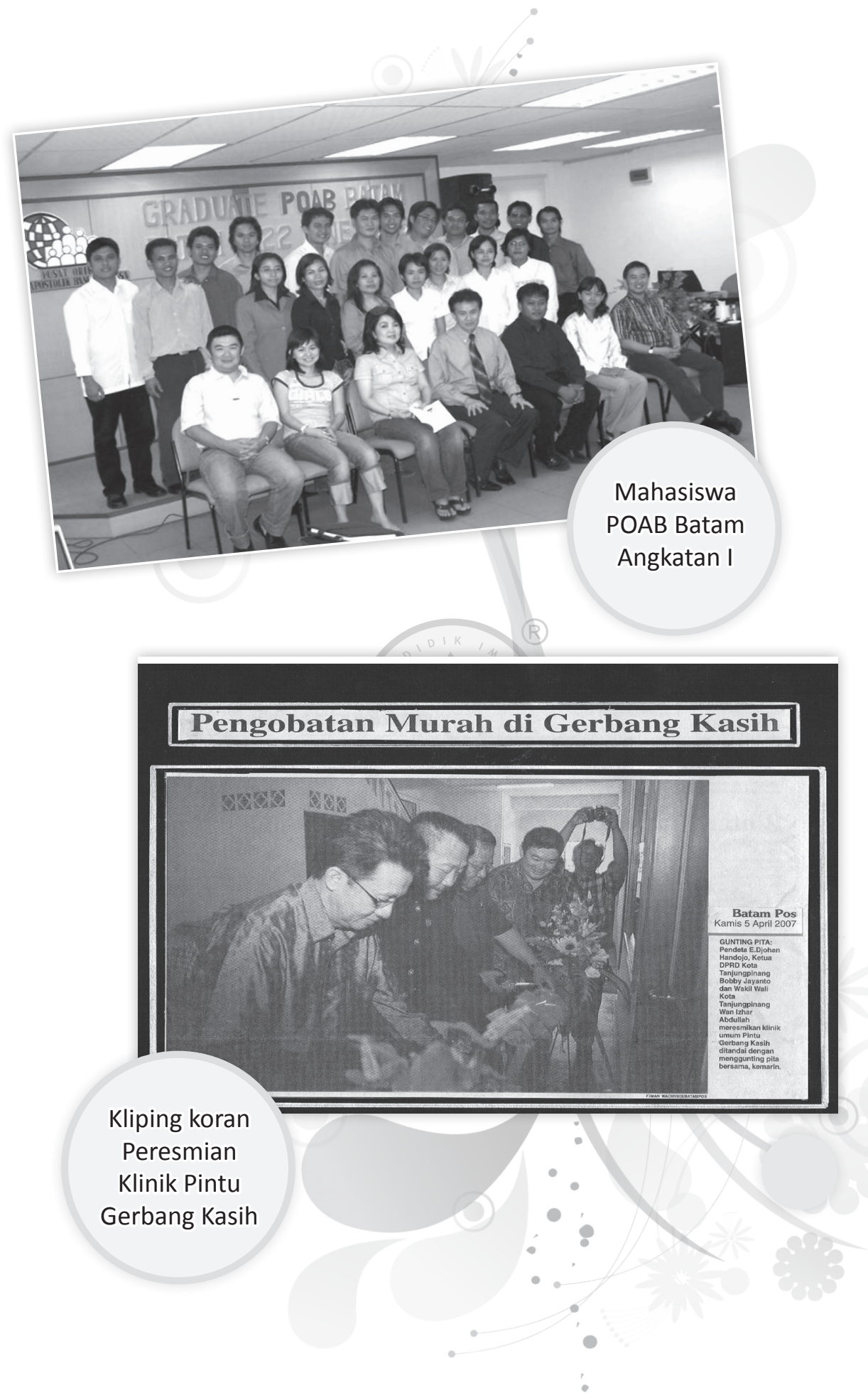




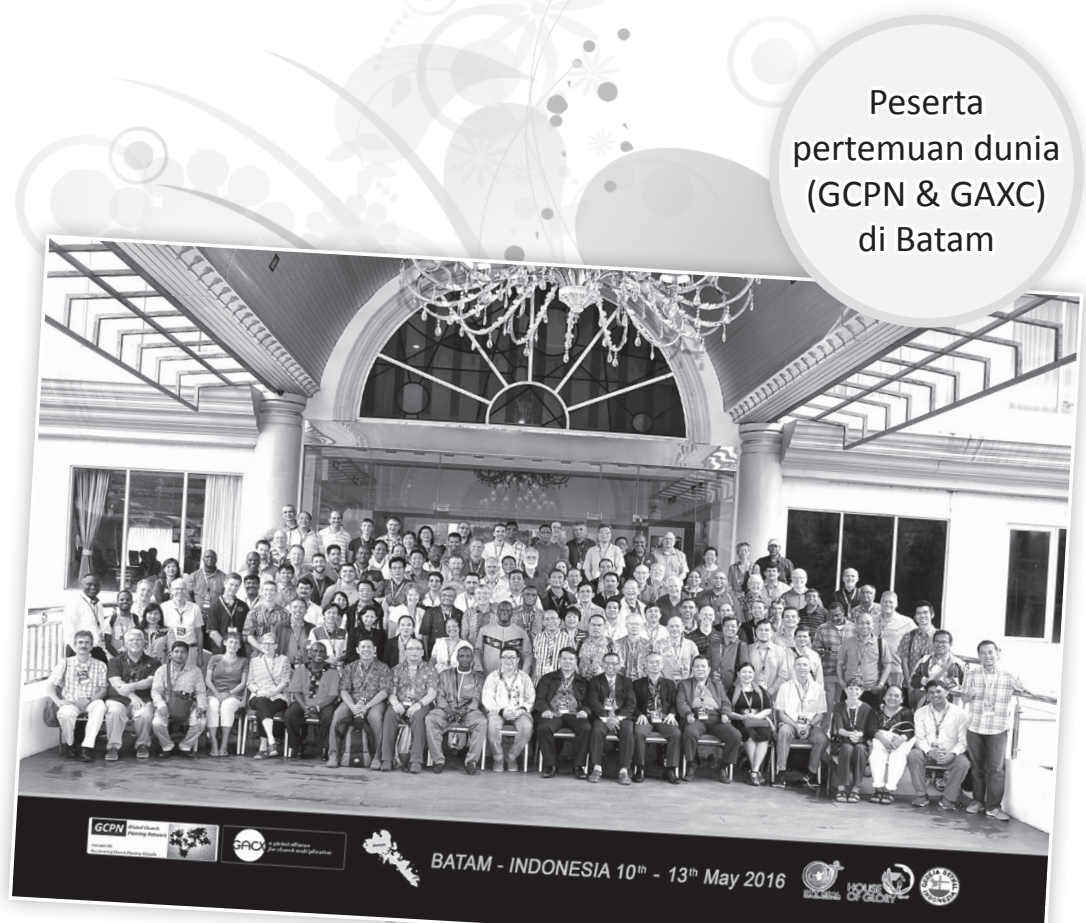

Doa keliling di puncak dataran yang paling tinggi di Kota Kathmandu Nagarkot

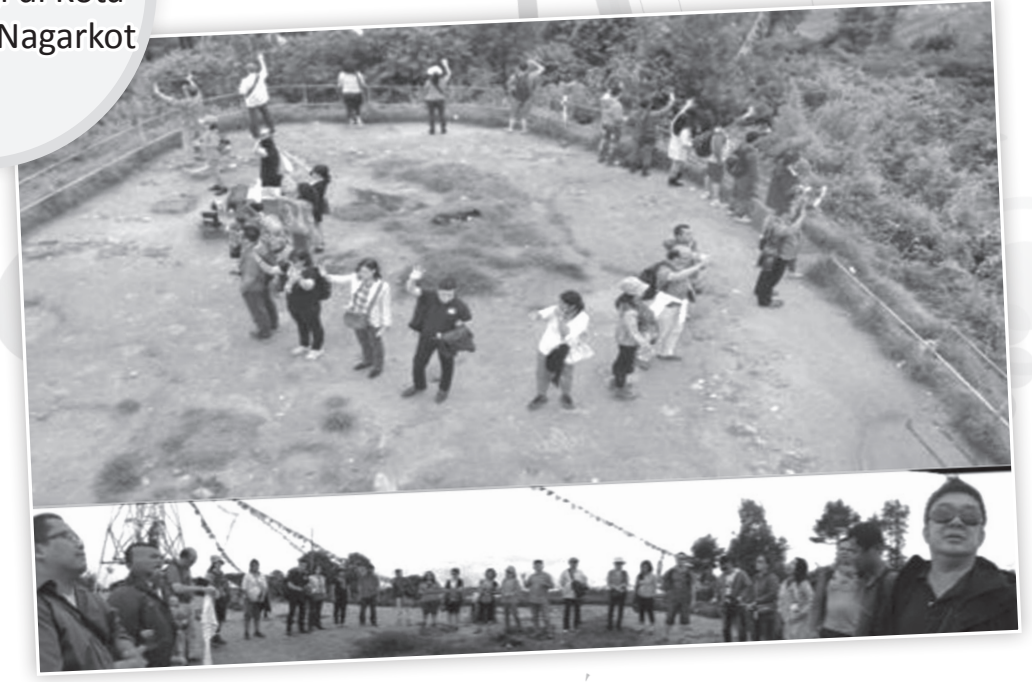




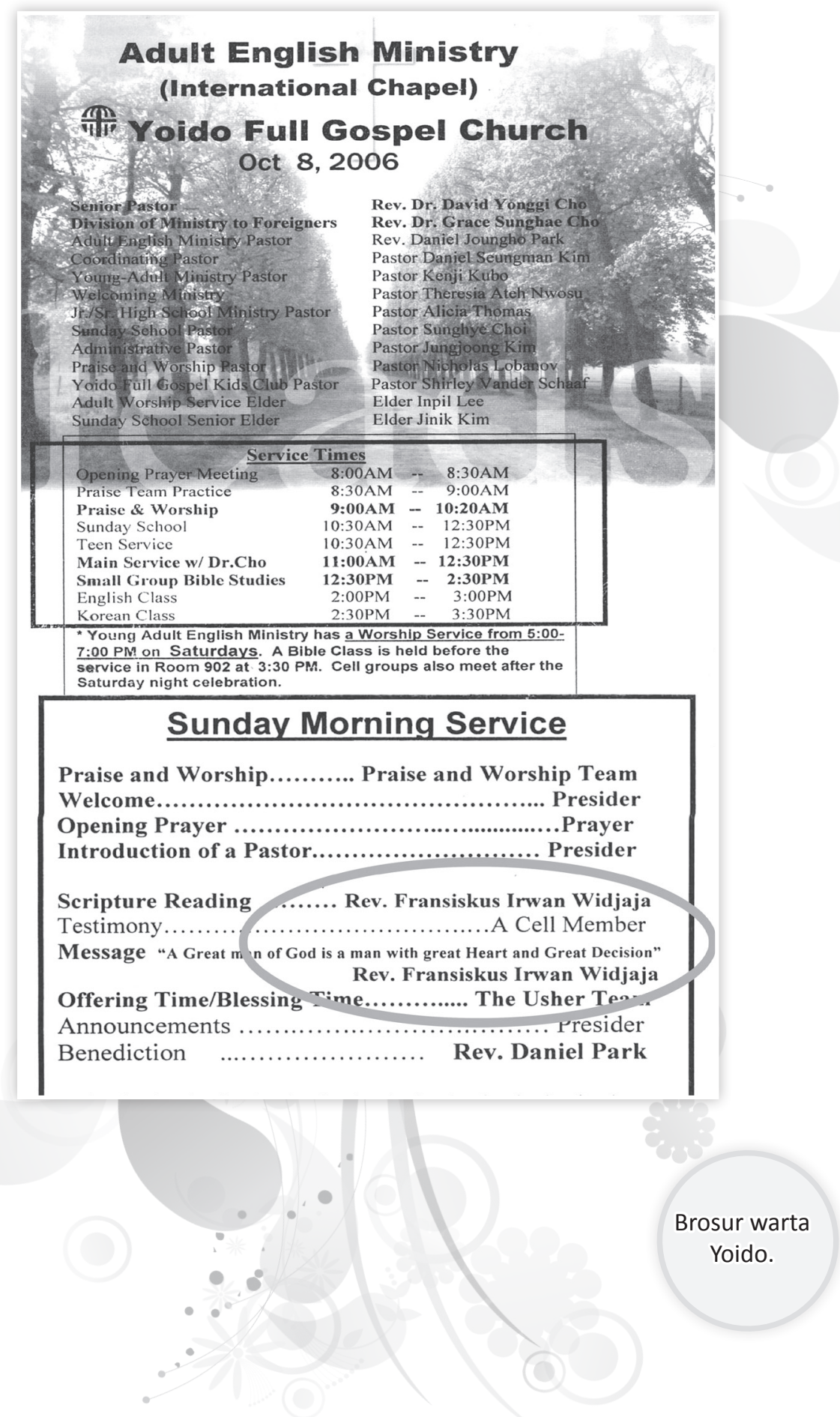

